UNIVERSIDADE DE BRASÍLIA

FACULDADE DE ADMINISTRAÇÃO, CONTABILIDADE, ECONOMIA E CIÊNCIA DA INFORMAÇÃO DEPARTAMENTO DE CIÊNCIA DA INFORMAÇÃO E DOCUMENTAÇÃO

LEANDRO LOPES TRINDADE

\title{
BIBLIOTERAPIA E AS BIBLIOTECAS DE ESTABELECIMENTOS PRISIONAIS: conceitos, objetivos e atribuições
}

\footnotetext{
Monografia apresentada ao Departamento de Ciência da Informação e Documentação da Universidade de Brasília como requisito parcial para obtenção do grau de Bacharel em Biblioteconomia.

Orientadora: Prof. ${ }^{\text {a Dr. }}$ ' Sofia Galvão Baptista
}

Brasília - DF 
UNIVERSIDADE DE BRASÍLIA (UnB)

Faculdade de Economia, Administração, Contabilidade e Ciência da Informação e Documentação (FACE)

Departamento de Ciência da Informação e Documentação (CID)

Título: Biblioterapia e Bibliotecas de estabelecimentos prisionais: conceitos, objetivos e atribuiçōes.

Aluno: Leandro Lopes Trindade

Monografia apresentada ao Departamento de Ciência da Informação e Documentação da Universidade de Brasilia, como parte dos requisitos para obtenção do grau de Bacharel em Biblioteconomia.

Brasília, 01 de dezembro de 2009.

Aprovada por:

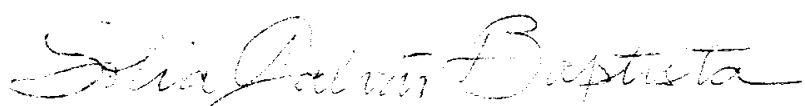

Sofia Galvão Baptista - Orientadora

Professora do Departamento de Ciência da Informação e Documentação (UnB) Doutora em Ciência da Informação
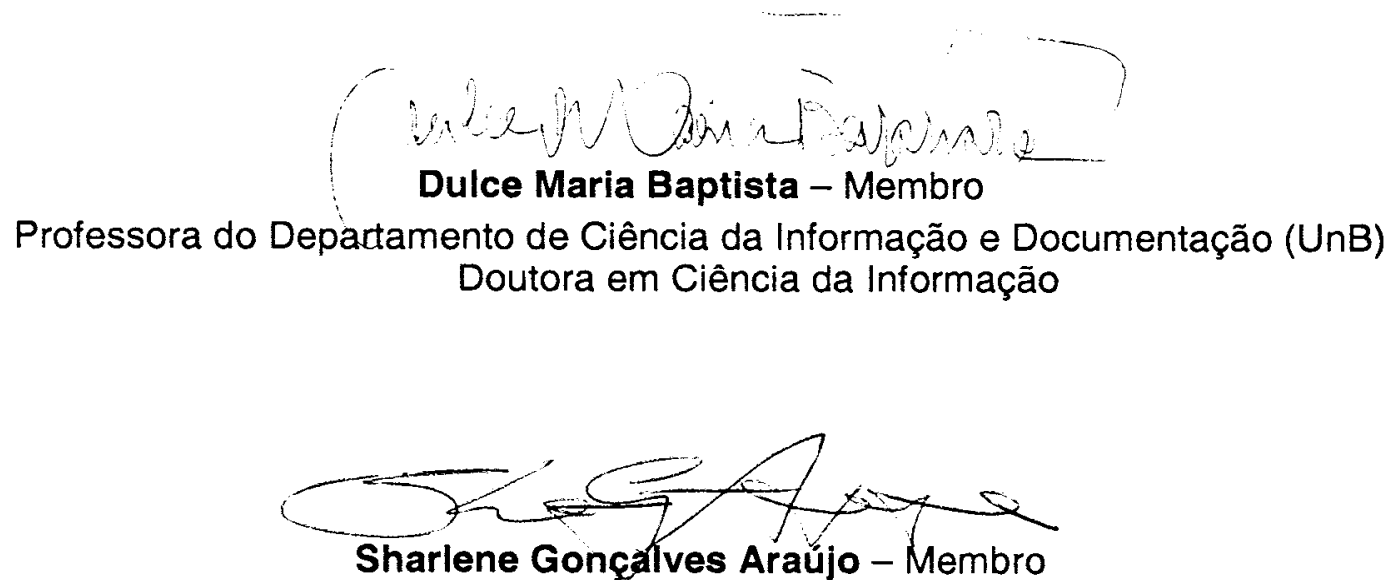

Bibliotecária Coordenadora das Bibliotecas do Sistema Prisional do DF 
Dedico este trabalho à minha mãe Erondina, por seu brio, esforço, amor, dedicação e demasiada importância em minha vida.

Ao meu pai Lauremi, que na sua sobriedade peculiar realça seu valor e sua inteligência admirável. Ao meu avô Lormino, pelo exemplo, dedicação e pelo empenho paterno.

In memoriam de minha avó Juvenília, pela benevolência, amabilidade e caridade. 


\section{AGRADECIMENTOS}

A Deus por sua eterna presença em minha vida e daqueles que amo.

À minha irmã Érica, por seu carinho e compreensão.

À Ana Cláudia, por seu carinho particular e amor inigualável.

À Professora Sofia Galvão Baptista, pelos ensinamentos, seu profissionalismo, estímulos, simpatia, paciência e "puxões de orelha", contribuindo para o desenvolvimento desse trabalho e o aperfeiçoamento profissional.

Aos amigos e amigas, pelo companheirismo, troca de experiências, descontração e carinho.

A todos os familiares, pelo incentivo.

A todos os professores da Universidade de Brasília e dos inúmeros estabelecimentos de ensino que passei, que com suas experiências e conhecimento, contribuíram grandiosamente, cada um, para meu crescimento intelectual.

À bibliotecária coordenadora das bibliotecas dos estabelecimentos prisionais do Distrito Federal, Sharlene Araújo, que com seu apoio e assistência colaborou para o bom desenvolvimento desse trabalho.

À Fundação de Amparo ao Trabalhador Preso, à Subsecretaria de Sistema Penitenciário e à Vara de Execuções Penais do Distrito Federal, pelas autorizações e deferimentos de requerimentos.

Aos internos do Centro de Internamento e Reeducação do Complexo Penitenciário da Papuda que responderam os questionários.

Enfim, a todos que tenham contribuído para que eu pudesse vencer mais uma etapa de minha vida, meus sinceros e eternos agradecimentos. 
“A prisão não são as grades, e a liberdade não é a rua; se existem homens presos na rua e homens livres na prisão, é tudo uma questão de consciência." (Mahatma Gandhi)

Dos diversos instrumentos do homem, o mais assombroso é, indubitavelmente, o livro. Os outros são extensões do seu corpo. O microscópio e o telescópio são extensões da vista; o telefone é o prolongamento da voz; seguem-se o arado e a espada, extensões do seu braço. Mas o livro é outra coisa: o livro é uma extensão da memória e da imaginação. (Jorge Luis Borges) 


\section{RESUMO}

Este trabalho analisa a biblioterapia e as bibliotecas de estabelecimentos prisionais, criando uma relação de proximidade entre as duas temáticas. Apresenta conceitos, objetivos, discussões e atribuições a respeito, identificando como o uso da leitura como recurso terapêutico contribui para o papel social das bibliotecas em meio prisional na ressocialização de indivíduos presos. Expõe o profissional da informação como mediador ou auxiliar da prática biblioterapêutica no ambiente carcerário. Aborda circunstâncias do Sistema Penitenciário: formação, evolução e situação atual do aparelho prisional brasileiro. Trata-se de uma pesquisa exploratória-descritiva, de natureza quantitativa-qualitativa. O estudo de caso da Biblioteca do Centro de Internamento e Reeducação - CIR, complementa toda a análise. A observação direta, a entrevista semi-estruturada e o questionário foram os instrumentos de coleta de dados. Foram verificados os benefícios esperados pelos detentos com o uso dos materiais de leitura; os materiais e conteúdos de interesse predominantes; constância, quantidade e o tempo gasto com a leitura; os sentimentos que os conteúdos lidos despertavam; utilização e reconhecimento da biblioteca prisional; entre outros. Os resultados encontrados demonstram e permitem compreender que os indivíduos encarcerados se rendem à relevância da leitura e de seus benefícios, requerendo maiores oportunidades de acesso às bibliotecas dos estabelecimentos prisionais e políticas de incentivo ao uso do livro como objeto ressocializador. Por meio do trabalho realizado, busca-se incentivar debates e pesquisas concernentes aos temas, oferecendo subsídios para a (re)educação e (re)inserção dos detentos à sociedade, compreendendo que a biblioterapia e as bibliotecas de estabelecimentos prisionais, entre outras representações, são determinantes em todo o processo.

PALAVRAS-CHAVES: Prisão. Leitura. Biblioterapia. Bibliotecas de estabelecimentos prisionais. Bibliotecário prisional. Biblioteca Nova Vida. Ressocialização. 


\section{RESUMEN}

Este trabajo analiza la biblioterapia y las bibliotecas de los centros penitenciarios, creando una relación estrecha entre los dos temas. Presenta los conceptos, objetivos, atribuiciones y discusiones acerca de cómo identificar el uso de la lectura como recurso terapéutico contribuye a la función social de las bibliotecas en las prisiones en la rehabilitación de las personas detenidas. Expone el bibliotecario como un mediador o auxiliar en la práctica de la biblioterapia en la cárcel. Acerca las circunstancias del sistema penitenciario: la formación, evolución y estado actual del Sistema Penitenciario brasileño. Este es un estudio exploratoriodescriptivo, de naturaleza cuantitativa y cualitativa. El estudio de caso de la Biblioteca del Centro de Internamento e Reeducação - CIR (Centro de Internamiento y Reeducación), complementa el análisis global. La observación directa, la entrevista no semiestructurada y el cuestionario fueron los instrumentos de reunión de datos. Fueron verificados los beneficios deseados por los detenidos con el uso de materiales de lectura; los materiales y contenidos de interés prevalecientes; la constancia, la cantidad y el tiempo dedicado a la lectura; los sentimientos que el contenidos leídos avivan; el uso y reconocimiento de la biblioteca de la prisión, entre otros. Los resultados demuestran y permiten comprender qué los indivíduos encarcelados reconocen la importancia de la lectura y sus beneficios, requerendo mayores oportunidades de acceso a las bibliotecas de los centros penitenciários y políticas de incentivo al uso del libro como un objeto resocializador. Por medio del trabajo realizado, foméntase la discusión y la investigación relativa a los temas, ofreciendo subsidios para la (re)educación y (re)integración de los reclusos en la sociedad, comprendiendo que la biblioterapia y las bibliotecas de centros penitenciarios, entre otras representaciones, son cruciales en el proceso.

PALABRAS CLAVE: Prisión. Lectura. Biblioterapia. Bibliotecas de centros penitenciarios. Bibliotecário prisional. Biblioteca Nova Vida. Resocialización. 


\section{LISTA DE ILUSTRAÇÕES}

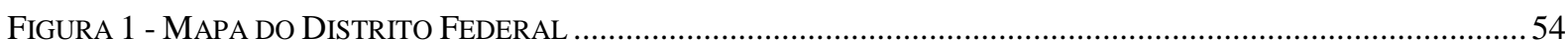

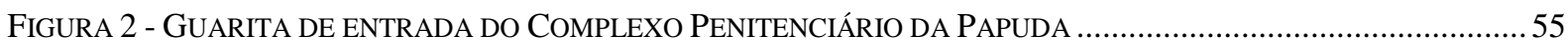

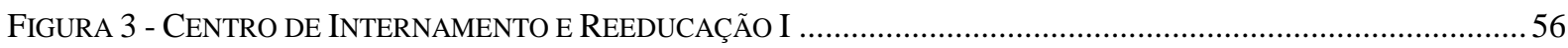

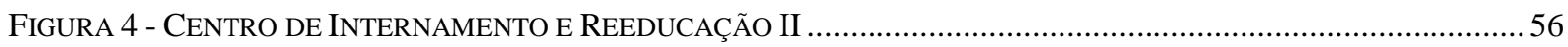

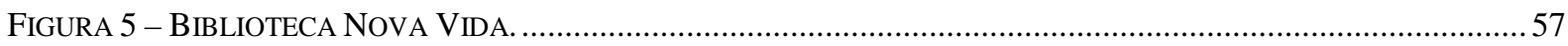

Figura 6 - PoRTA DE ENTRADA DA BIBLIOTECA Nova VIDA (VISÃo INTERNA). .................................................58

FigURA 7 - PorTa DE ENTRADA DA BIBLIOTECA NoVA VIDA (VISÃO EXTERNA)..................................................59

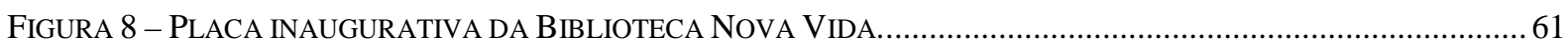

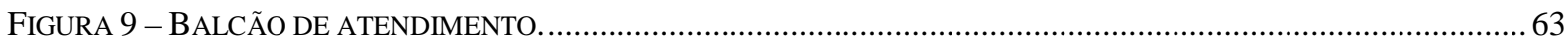

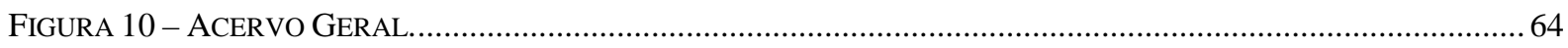

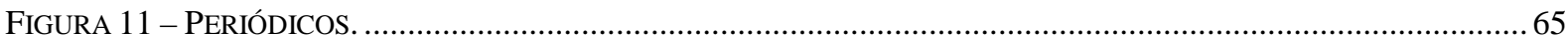

FigURA 12 - SiSTEMA DE CLASSIFICAÇÃO E GÊNEROS DOS DOCUMENTOS DA BNV ................................................. 66

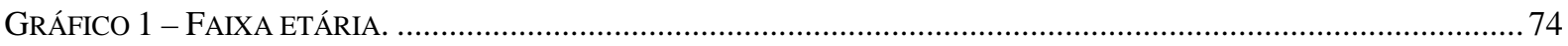

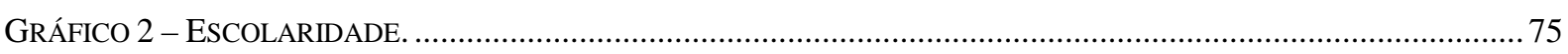

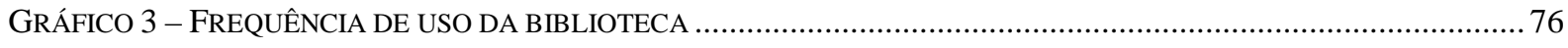

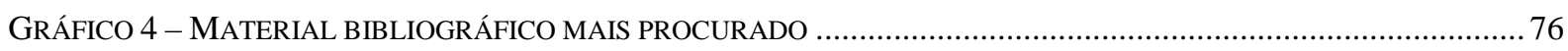

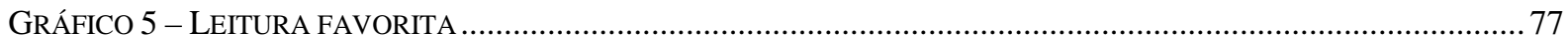

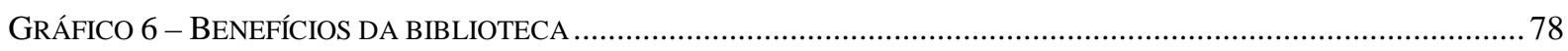

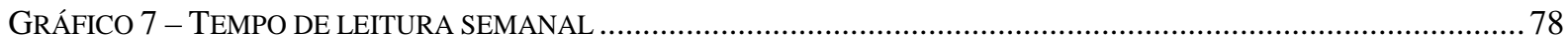

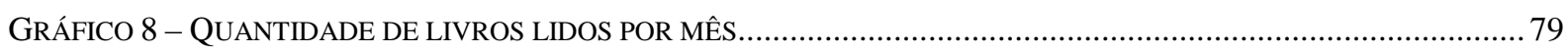

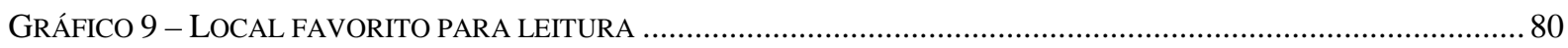

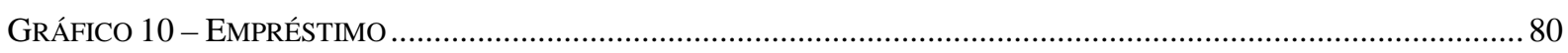

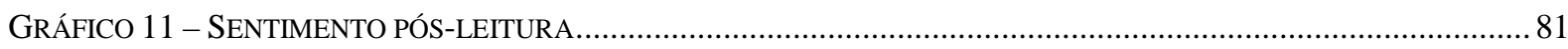

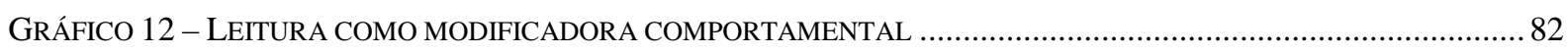

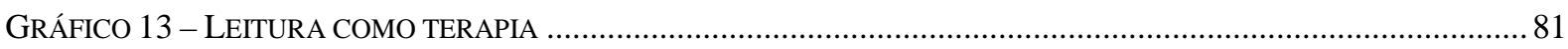

GRÁFICO 14 - VALORAÇÃO DA ASSISTÊNCIA PROFISSIONAL PARA ESCOLHER O QUE LER ……………………….... 84

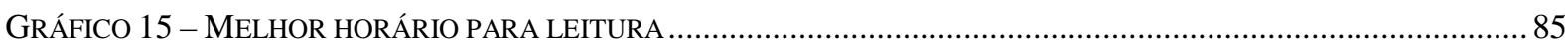

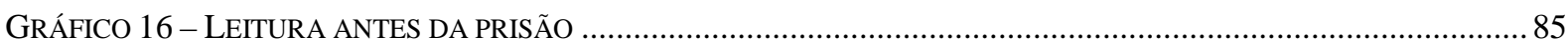




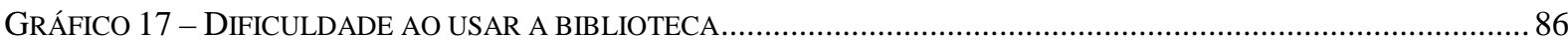

GRÁFICO 18 - CONCEITO DOS DETENTOS SOBRE A BIBLIOTECA PRISIONAIS …………………………................... 87 


\section{LISTA DE TABELAS}

TABELA 1 - POSSÍVEIS PROBLEMAS OCASIONADOS PELO MAL USO DE MATERIAIS

BIBLIOGRÁFICOS..

48

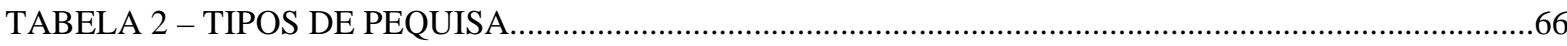

TABELA 3 - MÉTODOS PARA ESTUDO DE USUÁRIOS..........................................................................67 


\section{LISTA DE ABREVIATURAS E SIGLAS}

ALA - American Library Association (Associação Americana de Bibliotecas)

BDB - Biblioteca Demonstrativa de Brasília

BNV - Biblioteca Nova Vida

CDP - Centro de Detenção Provisória

CF - Constituição Federal do Brasil

CIR - Centro de Internamento e Reeducação

CNPCP - Conselho Nacional de Política Criminal e Penitenciária

CPP - Centro de Progressão Penitenciária

DEPEN - Departamento Penitenciário Nacional

DF - Distrito Federal

ECOSOC - Conselho Econômico e Social das Nações Unidas

EJA - Educação de Jovens e Adultos

FUNAP - Fundação Amparo ao Trabalhador Preso

GDF - Governo do Distrito Federal

IFLA - International Federation of Library Associations and Institutions (Federação Internacional de Associações e Instituições Bibliotecárias)

LDB - Lei de Diretrizes e Bases da Educação

LEP - Lei de Execução Penal

MJ - Ministério da Justiça

NCB - Núcleo de Custódia de Brasília

PDF I - Penitenciária I do Distrito Federal

PDF II - Penitenciária II do Distrito Federal

PFDF - Penitenciária Feminina do Distrito Federal

PNE - Plano Nacional de Educação

SEJUS - Secretaria de Estado de Justiça, Direitos Humanos e Cidadania do Distrito Federal VEP - Vara de Execuções Penais do Distrito Federal

UNESCO - Organização das Nações Unidas para a Educação, a Ciência e a Cultura 


\section{SUMÁRIO}

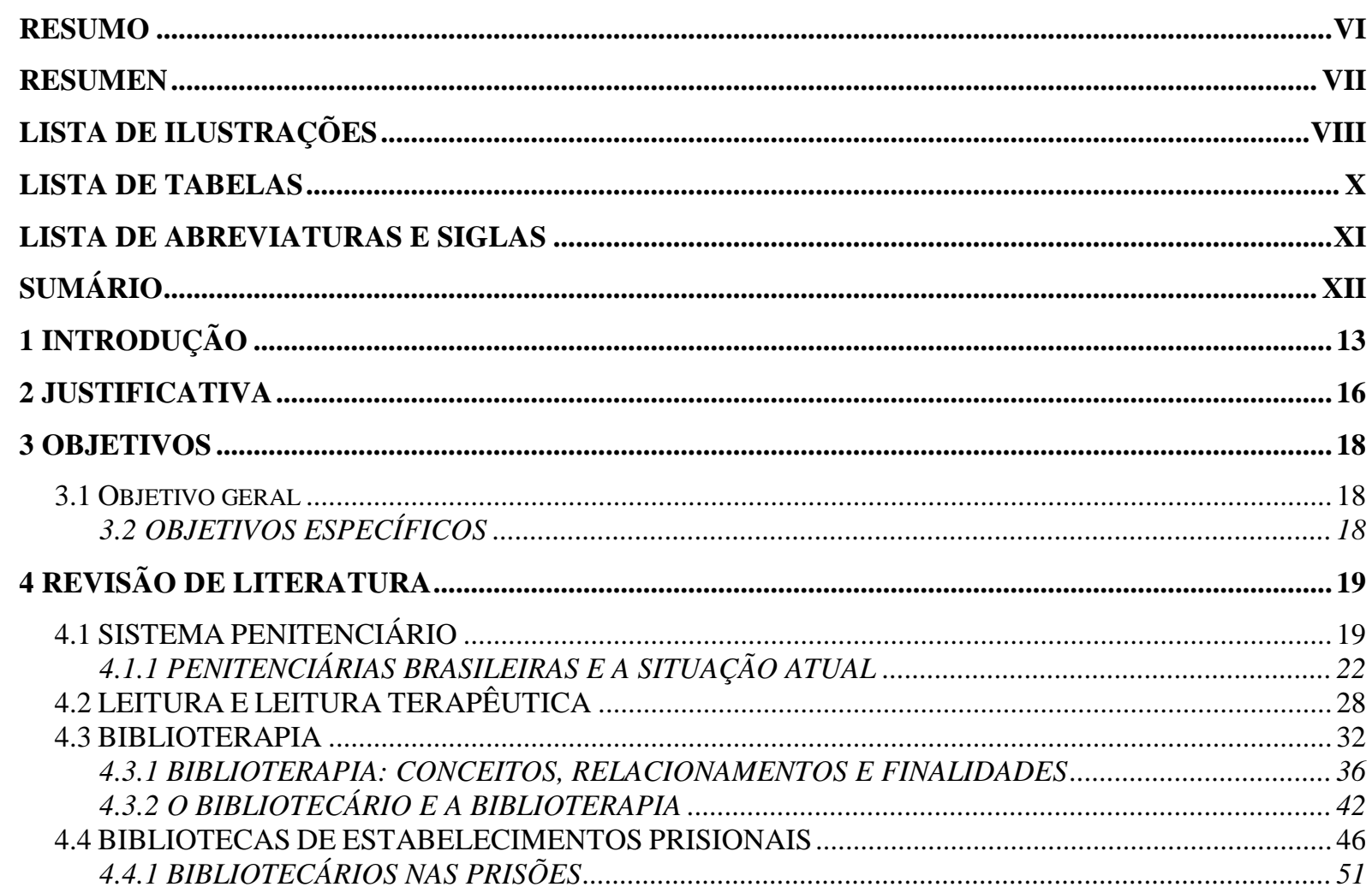

5 ESTUDO DE CASO: BIBLIOTECA DO CENTRO DE INTERNAMENTO E REEDUCAÇÃO

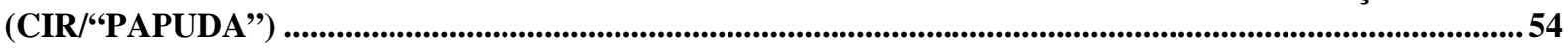

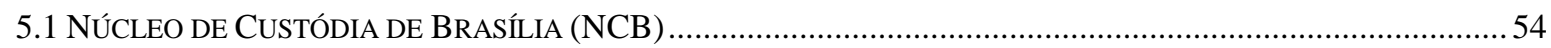

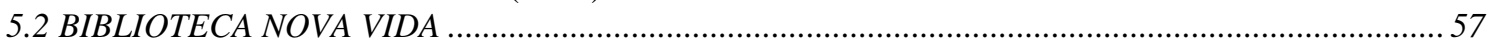

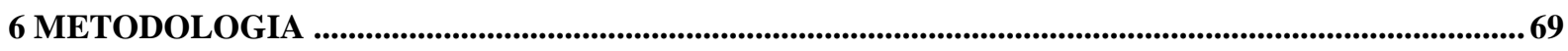

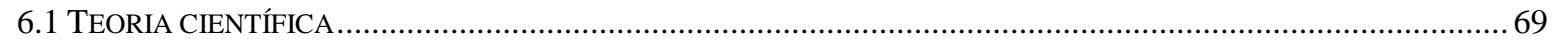

6.2 TIPO DE PESQUISA E FORMA DE EXECUÇÃO DAS ATIVIDADES ............................................................... 70

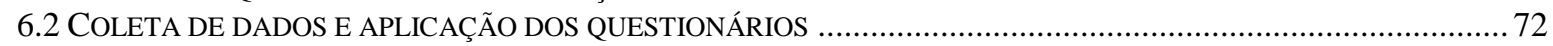

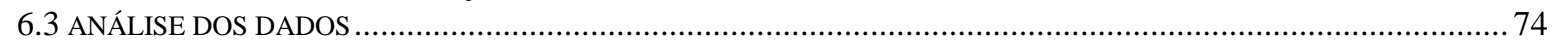

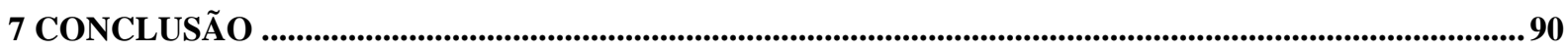

8 REFERENCIAS .................................................................................................................................94

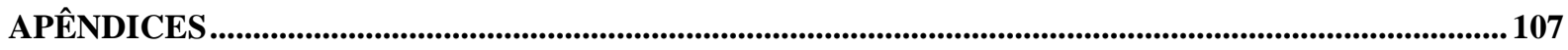

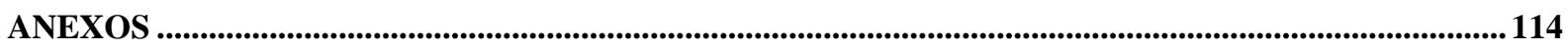




\title{
1 INTRODUÇÃO
}

\begin{abstract}
"No fim eu iria dizer a você que o papel do escritor é fazer o leitor ver o que ele, o escritor, viu. E o que o escritor vê não deve ser necessariamente a realidade convencional. [...] não era para ensinar você a ver o que pode ser visto, mas a ver o que não se vê" (Rubem Fonseca)
\end{abstract}

O tempo passa, as mudanças acontecem como uma coisa natural do desenvolvimento humano. Ao pararmos para contemplar ou simplesmente compararmos o passado à atualidade, percebemos o quanto todas as esferas da sociedade já foram afetadas pelas transformações naturais ou artificiais do decorrer do planeta Terra.

As mudanças trouxeram consigo o desenvolvimento tecnológico e social, as guerras, as catástrofes naturais, os movimentos migratórios, o aumento populacional e das desigualdades socioeconômicas, consequentemente, o aumento da violência e a multiplicação dos crimes nos mais diversos motivos e dimensões. Com o avanço da criminalidade, o Direito e os Sistemas Judiciários nacionais, ao longo das décadas, tiveram que buscar se aperfeiçoar para poder combater e tentar inibir os atos ilícitos.

As prisões passam a ser consideradas o ambiente destinado a punir, servir de exemplo para os demais, recuperar e ressocializar os indivíduos criminosos. Entretanto, os crimes não diminuíram, pelo contrário, só aumentaram com o tempo, e a prisões tornaram-se locais abarrotados de pessoas ociosas, estereotipadas, desprovidas de direitos civis, sociais, culturais e políticos.

Embora haja diversas determinações legais, nacionais ou internacionais, sobre como o preso deva ser tratado ou ressocializado, no caso brasileiro, o Sistema Penitenciário reflete a falência de políticas mal formuladas e de pouco investimento por meses, anos, décadas subseqüentes.

No Brasil, o Sistema Prisional tem a função de tentar corrigir mais de quatro centenas de milhares de homens e mulheres cometedores de crimes e condenados pela Justiça. A sociedade clama por segurança como um direito latente ao mesmo tempo em que detentos e reclusos bradam por assistência educacional, familiar, trabalhista, cultural, social e religiosa, ou seja, é inegável que a população reivindique seus direitos sociais, em especial o direito à segurança, estabelecidos no artigo $3^{\circ}$ da Declaração Universal dos Direitos Humanos ("Todo homem tem direito à vida, à liberdade e à segurança [...]") e no artigo $6^{\circ}$ da Constituição Federal brasileira de 1988 ("São direitos sociais a educação, a saúde, o trabalho, a moradia, o 
lazer, a segurança, [...]”), do mesmo modo, também, é válida a reclamação da observância das leis que amparam a população carcerária.

Julião (2007) afirma que a ausência de políticas públicas de investimento, recuperação e reinserção social que possam atender aos presos que cumprem suas sentenças dentro de instituições prisionais é fundamental para ineficácia punitiva e para o aumento da reincidência criminal.

Os estabelecimentos prisionais são considerados um universo de exclusão social, reflexo de uma sociedade desigual e injusta. Para ressociabilizar essa "minoria" proveniente, em sua maioria, da realidade social desigual, constróem-se programas de ressocialização baseados em políticas de execução penal em que atividades educacionais, profissionalizantes, culturais e religiosas tornam-se as bases e os objetos da efetividade da Justiça Criminal e do Sistema Penitenciário.

Nesse contexto, as bibliotecas de estabelecimentos prisionais podem ser consideradas importantes instrumentos de assistência, em razão de seu caráter "formativo, enquanto elemento central do processo de reinserção" (EIRAS, 2007, p. 1). Apesar de ainda desconhecida de grande parte da sociedade e dos profissionais de informação e documentação, as bibliotecas de estabelecimentos prisionais sofreram uma evolução conceitual ao longo do tempo, destacando-se como elemento imprescindível no amparo educacional, social e cultural do preso.

Como espaço cultural consagrado, a biblioteca tem o dever de incentivar a leitura como forma de aquisição de conhecimento, ocupação do tempo ocioso, entretenimento e desenvolvimento intelectual. Assim, o ato ler, além de todas as peculiaridades da leitura, ganha destaque nos espaços prisionais como apoio estrutural útil a realizar a formação de apenados que sofrem com a sensação de perdas pessoais e a descaracterização de identidade: processo subsidiário chamado de biblioterapia.

$\mathrm{O}$ ato de ler é de uma complexidade impressionante, uma vez que apreender letras está relacionado não somente com a visão e a percepção do sujeito, mas também com inferência, julgamento, memória, reconhecimento, conhecimento, experiência e prática. Junte-se a isso, o momento, o lugar e o suporte, pois eles também afetam a leitura, e teremos, então, a dimensão de tal complexidade. (MANGUEL apud FISCHBERG; DUARTE, 2007, p. 16).

A biblioterapia usa a leitura como elemento terapêutico no tratamento ou crescimento pessoal do indivíduo que esteja sofrendo por doenças, dificuldades psíquicas, emocionais ou, até mesmo, físicas. 
Biblioterapia pode ser tanto um processo de desenvolvimento pessoal como um processo clínico de cura,[...] com o propósito de promover a integração de sentimentos e pensamentos a fim de promover autoafirmação, autoconhecimento ou reabilitação" (MARCINKO, 1989 apud FERREIRA, 2003).

Em estabelecimentos prisionais a biblioterapia pode ser aproveitada, ainda, como técnica de mudança de comportamento, educação e reabilitação social, pois a leitura terapêutica não traz consigo somente o sentido curativo, mas também o aspecto preventivo.

O presente trabalho objetiva, por meio de fundamentação teórica, apresentar a relevância da leitura e seu uso como método terapêutico: biblioterapia. Igualmente, pretendese evidenciar o valor das bibliotecas em estabelecimentos prisionais e do profissional bibliotecário, relacionando-o tanto à biblioterapia quanto às bibliotecas de estabelecimentos prisionais.

Estruturou-se o trabalho em capítulos, no qual a primeira etapa expõe-se a justificativa e os objetivos. Em seguida, encontra-se a revisão de literatura sobre o Sistema Penitenciário, leitura, biblioterapia e bibliotecas de estabelecimentos prisionais estabelecendo relação destes com o profissional da informação. O estudo de caso sobre a Biblioteca do Centro de Internamento e Reeducação do Complexo Penitenciário da Papuda do Distrito Federal complementa o trabalho. Posteriormente, encontra-se a descrição da metodologia e análise dos dados obtidos com o instrumento de pesquisa adotado. Por fim, fecha-se o trabalho com as considerações finais. 


\section{JUSTIFICATIVA}

"A leitura é um tema muito explorado no meio acadêmico e também fora deste, e já ficou mais do que provada a sua importância e valor" (OLIVEIRA, D., 2004). Quando observado o uso da leitura para fins terapêuticos, ainda sim, temos grandes e valiosos estudos e análises. Entretanto, pouco se investiga e se discuti sobre as bibliotecas de estabelecimentos prisionais e da aplicação da biblioterapia em instituições carcerárias, igualmente, há escassos trabalhos relatando a relevância do bibliotecário neste contexto.

Ao se observar as prisões, sua história e atualidade, percebe-se o quanto esses locais são estigmatizados. Nota-se que sua imagem é tida como um ambiente abarrotado de homens ou mulheres (ou mesmo de adolescentes, no caso dos centros de atendimento juvenis) ferozes, sem alma, sem sentimentos, incapazes de pensar ou fazer o bem e, muito menos, inúteis no que diz respeito à busca pelo conhecimento, pela cultura e pela educação. Todavia, essa idéia plural não é totalmente a verdadeira, apesar dos Centros Penitenciários serem, em sua maioria, recintos sujos, desagradáveis à vista e deprimentes, a quase totalidade das pessoas que hoje estão detidas ou reclusas, independentemente de seus crimes, clamam por ajuda, por um sítio de melhor qualidade, sem inúmeros indivíduos disputando o mesmo espaço, e também, por estudo, por cultura, por educação, por profissionalização, por atividades que eliminem o ócio e desenvolvam as faculdades intelectuais e morais.

A leitura, com sua polivalência, no contexto prisional, desponta como uma excelente atividade de ocupação do tempo e da mente, além de oportunizar aos detentos o engrandecimento do intelecto e ganho de conhecimento. Por meio de "um bom texto literário ou qualquer outra obra de qualidade, permitem, pela sua profundidade, uma compreensão e construção em vários níveis", ajudando os indivíduos a encontrarem o sentido de suas vidas (GOODMAN, 1991 apud FERREIRA, 2003, p. 42).

John (2004, p. 57) afirma que os materiais bibliográficos referentes "à prática da leitura no ambiente prisional é bastante restrita" e mesmo que grande parte dos países do mundo preguem "o acesso à educação e a disponibilidade de bibliotecas como condição indispensável para a reeducação/reinserção" dos presos, ainda há uma vultosa carência de "acesso dos detentos aos materiais de leitura".

A problemática das prisões brasileiras, seu mundo insular e a necessidade iminente, entre as muitas dificuldades, de assistência educacional, cultural e psicológica, surgiram como inquietações introdutórias para desenvolvimento do trabalho. 
$\mathrm{O}$ interesse pelo conhecimento das bibliotecas presentes em instituições de internamento, como hospitais, asilos, spas, centros de apoio a doentes mentais, etc., sobretudo, pelas bibliotecas de estabelecimentos prisionais, unido à estima pelo poder da leitura serviram de fundamentos para a concepção da proposta temática abordada nesse trabalho.

Assim, o estudo sobre a biblioterapia e as bibliotecas de estabelecimentos prisionais, juntando-se às perspectivas o papel do bibliotecário em meio prisional, justifica-se por sua importância, estimulando a reflexão e o interesse de pesquisas diversas sobre as proposições analisadas. 


\section{OBJETIVOS}

\subsection{Geral}

A partir da percepção bibliográfica, abordando a temática da situação carcerária brasileira, objetiva-se identificar como a biblioterapia contribui para o papel social das bibliotecas de estabelecimentos prisionais na ressocialização de indivíduos presos.

\subsection{Específicos}

Para a consecução do objetivo geral, foram elencados os seguintes objetivos específicos:

Identificar se existe(m) lei(s) em vigência no Estado brasileiro que proporcione condições de integração social ao condenado;

$>$ Identificar como o tratamento biblioterapêutico (biblioterapia) pode subsidiar o processo de reinserção do preso à sociedade;

> Analisar o papel pedagógico das bibliotecas de estabelecimentos prisionais;

> Identificar o papel do bibliotecário como mediador do acesso à leitura no ambiente prisional;

$>$ Verificar se o detento tem consciência da importância da leitura e de seus benefícios. 


\title{
4 REVISÃO DE LITERATURA
}

\subsection{SISTEMA PENITENCIÁRIO}

\begin{abstract}
"Conhecem-se todos o inconvenientes da prisão, e sabe-se que é perigosa quando não inútil. E, entretanto, não 'vemos' o que pôr em seu lugar. Ela é a detestável solução, de que não se pode abrir mão" (Michel Foucault).
\end{abstract}

Prisão, do latim prehensione, tem como conceito ser o ato de enclausurar, manter em cárcere qualquer indivíduo que cometa um ato delituoso, em desacordo com as leis vigentes em qualquer Estado, desde que estas preconizem tal efeito; caracteriza-se, ainda, por ser um espaço institucional da justiça moderna, arquitetado de forma a acolher pessoas condenadas pelos tribunais. Em sentido Bíblico, prisão se relaciona com o estado espiritual pós-morte, mais diretamente ligado ao estado de consciência, dos pecados cometidos em vida.

Atualmente o conceito de prisão e seus temas correlatos estão intrinsecamente imbuídos de muitos preconceitos ou opiniões pré-formadas, pois hoje vivemos numa situação em que as prisões e todo sistema penitenciário estão rodeados de fantasmas sociais e lançados à margem da sociedade, ganhando destaque somente em momentos de conflitos.

Goffman (2003 apud Gouvêa, 2007) utiliza o termo 'instituição total' para se referir à prisão, onde o condenado será controlado hierárquica e administrativamente em todas as suas ações e necessidades. A rigidez das regras e horários é vista como um "plano racional único, supostamente planejado para atender aos objetivos oficiais da instituição” (p. 57).

[...] instituição total pode ser definida como local de residência e trabalho onde um grande número de indivíduos em situação semelhante, separados da sociedade mais ampla por considerável período de tempo, levam uma vida fechada e formalmente administrada [...] (GOFFMAN, 2003, p. 11)

Na antiguidade, a prisão tida como sinônimo de privação de liberdade era desconhecida, era considerada apenas como uma forma de execução penal e mesmo em momentos em que o delinqüente era mantido encarcerado, esse método não tinha função de pena, mas somente caráter de preservação, ou seja, mantinha-se o réu privado de sua liberdade até o seu julgamento ou execução. Por séculos a prisão teve como finalidade, para nossos ancestrais, ser um lugar para realização de martírios e de custódia ou apenas uma forma de garantia de cumprimento do julgamento e/ou da sentença. 
A par dessa função preventiva, a prisão era também utilizada para pressionar os indivíduos a honrar compromissos sociais relacionados com o pagamento de multas ou dívidas. Pontualmente, a prisão aparecia com um caráter misto, coercivo e repressivo (EIRAS, 2007, p. 1).

A pena prisional teve seu surgimento com a influência eclesiástica, no direito canônico, e até o século XII era exclusiva para alguns poucos criminosos. Muakad (1984, p. 16) afirma que a palavra penitência que acabou por derivar a palavra penitenciária, no princípio do

cristianismo significava 'volta sobre si mesmo', com o espírito de compunção, para reconhecer os próprios pecados (ou delitos), abominá-los, e propor-se a não tomar a reincidir. É a própria pena exercendo a função de emenda, eis que pena e penitência são palavras da mesma família, em cujo sentido se encontra a idéia de aflição, dor, desgosto, arrependimento [...].

Para Magnabosco (1998, online), "Platão propunha o estabelecimento de três tipos de prisões: uma na praça do mercado, que servia de custódia; outra na cidade, que servia de correção, e uma terceira destinada ao suplício. A prisão, para Platão, apontava duas idéias: como pena e como custódia."

Em 1596, a mais antiga arquitetura carcerária holandesa, foi o modelo de Amsterdã Rasphuis, para homens, que se destinava em princípio a mendigos e jovens malfeitores a penas leves e longas com trabalho obrigatório, vigilância contínua, exortações e leituras espirituais. Historicamente, o modelo holandês liga teoria a uma transformação pedagógica e espiritual dos indivíduos, e as técnicas penitenciárias imaginadas no fim do século XVII, deu direcionamento às atuais instituições punitivas.

Segundo Eiras (2007), o primeiro a analisar a ligação entre o nascimento da prisão como "dispositivo penal e forma de punição" foi o filósofo francês Michel Foucault (19261984), fazendo uma ligação com a idéia de que o delito deva ser identificado e punido de "acordo com o princípio corretivo fundamentado nos desígnios da época histórica vigente na religião, na moral, na sociedade e também na classe intelectual dominante".

De acordo com Foucault (2004, p.195):

Ela [a prisão] se constituiu fora do aparelho judiciário, quando se elaboraram, por todo o corpo social, os processos para repartir os indivíduos, fixá-los e distribuí-los espacialmente, classificá-los, tirar deles o máximo de tempo, e o máximo de forças, treinar seus corpos, codificar seu comportamento contínuo, mantê-los numa visibilidade sem lacuna, formar em torno deles um aparelho completo de observação, registro e anotações, constituir sobre eles um saber que se acumula e se centraliza. A forma geral de uma aparelhagem para tornar os indivíduos dóceis e úteis, através de um trabalho preciso sobre seu corpo, criou a instituição-prisão, antes que a lei a definisse como a pena por excelência. No fim do século XVIII e princípio do século XIX se dá à passagem a uma penalidade de detenção, é verdade; 
e era coisa nova. Mas era na verdade abertura da penalidade a mecanismos de coerção já elaborados em outros lugares.

Durante as Ordenações Manuelinas, período de elaboração e normatização das leis em Portugal de 1512 a 1595, a prisão nasce como um método de prevenção, sendo mantido o mesmo caráter em meio às Ordenações Filipinas (1603-1867), apesar de estas usarem o encerramento de modo mais coercitivo.

Até o século XVIII era comum o uso metódico de espancamentos como forma de punição pública, no qual o acusado tinha como alvo de sua punição o seu corpo. Podendo ir de pequenos castigos corporais como açoitamentos até a pena de morte com elevada violência, perpassando por amputações e humilhações extremas. Já no final do mesmo século XVIII, o corpo deixa de ser o objeto de repreensão e começa a se buscar formas de correção em que a reflexão do indivíduo passa a ser o objeto punitivo. A alma do delituoso torna-se o foco, objetivando-se com isso criar penas privativas de liberdade em que os indivíduos, por meio de uma reeducação moral, do trabalho e disciplina pudessem ser corrigidos e reinseridos no meio social.

Cesare Beccaria, filósofo italiano influenciado pelos iluministas e colaborador do pensamento científico do Direito Penal, em sua obra 'Dos delitos e das penas' (1794), manifesta-se contrário à tradição jurídica vigente até o século XVIII de julgamentos secretos e do uso recorrente da tortura como instrumento de confissão, bem como às diferentes formas de castigos relacionadas à classe social e o confisco de bens dos condenados. Para Beccaria era necessária a proporcionalidade das penas em nome da humanidade e da razão penal. $\mathrm{O}$ direito de vingança e a pena de morte são do mesmo modo condenados pelo autor.

Perrot (1994, p. 236) expõe:

A ampliação da prisão é correlata, visto que o encarceramento funda a organização
penitenciária contemporânea. O Antigo Regime certamente conhecera os cárceres,
mas antes depósitos, despejos, locais de passagem do que de permanência e
penitência, parênteses para outras penas ou outros lugares: o encarceramento não
constituía a pedra angular da repressão. 'Inventando a liberdade' (Starobinski), a
Revolução simultaneamente gera seu contrário. Fazendo da pena privada da
liberdade o ponto de sustentação do sistema penal, ela tece as primeiras malhas
dessa imensa rede - casa de justiça, de detenção, de correção, centrais,
departamentais... - que aos poucos iria recobrir todo o país. História dramática e
profundamente contraditória. Feita para punir, mas também para reintegrar os
delinqüentes à sociedade, 'corrigir os costumes dos detentos, a fim de que seu
retorno à liberdade não seja uma desgraça nem para a sociedade, nem para eles
mesmos', a prisão acaba por excluí-los.

Já no final do século XX e início do século XXI, a prisão e sua exclusão simbólica, adquirida durante todo processo histórico, passaram a ganhar maior evidência, também 
influenciada pela batalha diária dos meios de comunicação, no qual a mídia sensacionalista busca explorar qualquer fato que possa dar audiência.

O mercado editorial começa a enxergar nos relatos dos presos um 'novo filão', ou seja, uma nova fonte de pesquisa, um novo assunto a ser explorado; a indústria fonográfica investe no rap produzido dentro das cadeias; filmes e documentários buscam retratar a realidade carcerária (BARBOSA, 2007, p. 19).

Barbosa (Ibid.) descreve que atualmente, não somente os aprisionados são rotulados e menosprezados pela grande maioria da população, mas também, familiares de cada encarcerado, o próprio estabelecimento prisional, bem como seus funcionários "são postos sob um véu de chumbo, possibilitando que se criem sobre eles os mais diversos preconceitos".

Dessa forma, Perrot (1994 apud OLIVEIRA, D., 2004, p. 111) complementa:

O sistema penitenciário parece então ter se desviado profundamente de suas intenções iniciais. Longe de reintegrar, ele expulsa, evacua, suprime os irrecuperáveis. Mas ao mesmo tempo revela talvez sua finalidade oculta e verdadeira: defender a sociedade industrial burguesa fundada sobre a propriedade e o trabalho. A prisão é a ilusória válvula de segurança dessa sociedade.

\subsubsection{PENITENCIÁRIAS BRASILEIRAS E A SITUAÇÃO ATUAL}

"O mesmo Estado que é a razão pela qual as pessoas caem na criminalidade é o Estado que, ao invés de tentar salvar, só tem como resposta a punição" (Luis Inácio Lula da Silva)

“A história das organizações prisionais no Brasil data de 1551, aproximadamente, quando os criminosos eram recolhidos nas Câmaras Municipais em celas separadas por grades e mantinham contato com transeuntes". (MACRI; SALAZAR, 2005, p. 53).

No Brasil, até o fim do século XIX, existiam como modelos de prisões as chamadas cadeias públicas que dividiam o mesmo espaço predial com a Câmara Municipal da cidade. O interior das cadeias era composto por celas, salas e compartimentos subterrâneos úmidos e escuros - enxovias - onde homens e mulheres eram presos e podiam até compartilhar do mesmo ambiente. Havia, ainda, salas-livres, designadas pelo sistema judiciário da época para que o réu cumprisse a pena fora do cárcere, também existiam as salas de segredo ou moxinga, onde realizavam os interrogatórios, muitas vezes com o uso de torturas. "Além das prisões comuns existia o aljube, destinada ao encarceramento de pessoas que cometeram crimes eclesiásticos ou de lesa-majestade" (OLIVEIRA, F., 2007, p. 10). 
A característica mais acentuada entre as diferenças das prisões coloniais e do período imperial não dizia respeito à arquitetura, pois em sua maioria permanecia a mesma, entretanto, quanto à sua administração, passou dos domínios municipais para a esfera de ação do poder imperial e, posteriormente, quando da independência do Brasil e formulação da primeira Constituição e o surgimento das primeiras leis concernentes às prisões, passou a ser dos estados do país.

Em 11 de julho de 1984 entrou em vigor a Lei $\mathrm{n}^{\text {o }}$ 7.210, conhecida como Lei de Execuções Penais (LEP), tendo como finalidade realizar os preceitos legais a respeito de sentenças ou decisões criminais e oferecer condições harmônicas para bem-estar do sentenciado e do internado.

Antônio Silva, (2000, online) afirma:

No Brasil a primeira tentativa de editar-se uma Lei referente à execução penal, foi o Código Penitenciário da República, no ano de 1933, tendo sido abandonado em face da edição do atual Código Penal de 1940, do qual discrepava. Houve a edição da Lei $\mathrm{n}^{\circ} 3.274$, de 02 de outubro de 1957, que dispunha sobre normas gerais do regime penitenciário que vigorou até a vigência da Lei $\mathrm{n}^{\circ}$ 7.210/84.

A LEP (Lei $n^{\circ}$ 7.210/84) prega em seu artigo 10 ser dever do Estado a reinserção social do preso, a prevenção contra a reincidência e a assistência necessária para que esta reinclusão seja efetivada. De acordo com a LEP, esta assistência será: "material; à saúde; jurídica; educacional; social e religiosa" (Art. 11).

Apresentando como exemplo a assistência educacional, a Lei de Execuções Penais dispõe que o amparo deva ser feito por meio de "instrução escolar e formação profissional do preso e do internado" (art. 17), podendo constituir-se convênio com entidades públicas ou privadas para que as atividades educacionais sejam realizadas. Afirma, ainda, em seu art. 21 que "em atendimento às condições locais, dotar-se-á cada [grifo nosso] estabelecimento de uma biblioteca, para uso de todas as categorias de reclusos, provida de livros instrutivos, recreativos e didáticos". Entretanto, pouco ou quase nada, de tudo que a Lei $\mathrm{n}^{\circ}$ 7.210/84 preconiza, em especial, os temas relativos às assistências, é concretizado atualmente.

Em seu artigo 61, a LEP estabelece que órgãos da execução penal brasileira são compostos por:

I - O Conselho Nacional de Política Criminal e Penitenciária;

II - o Juízo da Execução;

III - o Ministério Público;

IV - o Conselho Penitenciário;

V - os Departamentos Penitenciários;

VI - o Patronato;

VII - o Conselho da Comunidade. 
O Conselho Nacional de Política Criminal e Penitenciária (CNPCP) é o primeiro dos órgãos de cumprimento penal, seu funcionamento é anterior a promulgação da Lei de Execução Penal (foi instalado na Capital da República em junho de 1980), tem como função implementar uma política criminal e penitenciária de melhoramento de todo sistema, tendo como incumbência, entre vários temas, "propor diretrizes da política criminal quanto à prevenção do delito, administração da justiça criminal e execução das penas e das medidas de segurança." (Lei no 7.210/84, Art. 64, inciso I).

O órgão responsável pela execução de políticas penitenciárias em âmbito nacional, de apoio administrativo e financeiro ao Conselho Nacional de Política Criminal e Penitenciária é o Departamento Penitenciário Nacional (Depen) subordinado diretamente ao Ministério da Justiça.

Os 1.134 estabelecimentos prisionais brasileiros, de acordo com o MJ, estão distribuídos em diferentes categorias, incluindo penitenciárias, presídios, cadeias públicas, casas de detenção e distritos ou delegacias policiais. Os estabelecimentos penais são conceituados e classificados de acordo com o objetivo de cada um. A Lei de Execução Penal institui que serão:

\footnotetext{
a) Estabelecimentos Penais;

b) Estabelecimentos para Idosos;

c) Cadeias Públicas;

d) Penitenciárias;

d.1) Penitenciárias de Segurança Máxima Especial;

d.2) Penitenciárias de Segurança Média ou Máxima;

e) Colônias Agrícolas, Industriais ou Similares;

f) Casas do Albergado;

g) Centros de Observação Criminológica;

h) Hospitais de Custódia e Tratamento Psiquiátrico.
}

O Distrito Federal, por exemplo, contava em dezembro de 2007, segundo Dados Consolidados de 2007 do Sistema Nacional de Informação Penitenciária, com 6 estabelecimentos penitenciários, uma população carcerária, incluindo homens e mulheres em todos os regimes prisionais, de 8.132 presos (população carcerária do $1^{\circ}$ semestre de 2009 , segundo o Ministério da Justiça), porém, desse montante, só haveria vaga disponível para 6.617 reclusos. Ou seja, observa-se que no DF, desde o final de 2007 já existia um déficit de 22,9\% de vagas no Sistema Penitenciário Distrital.

O sistema prisional brasileiro é um dos maiores do mundo, tem hoje mais de 409 mil presos (dados do MJ de 2009), computando-se apenas a população das prisões estaduais e aqueles detentos que estejam cumprindo regime fechado ou semi-aberto, quando incluídos 
todos os regimes prisionais, também a população carcerária das delegacias de polícia e das penitenciárias federais, esse número alcança cerca de 470 mil presos (MJ, 2009).

Da mesma forma que temos um das maiores populações prisionais do mundo, também temos, proporcionalmente, um dos piores sistemas de encarceramento. Segundo pesquisa realizada pelo Ministério da Educação em conjunto com o Ministério da Justiça em 2007, há um grande déficit de vagas em todo o sistema prisional brasileiro. Seria preciso criar aproximadamente 150 mil novas vagas para que se pudesse acabar com a superlotação nas prisões, salientando-se, que tal estimativa só se configura caso não se cumpra os mais de 300 mil mandados de prisão pendentes na Justiça.

Segundo dados de 2006 do Ministério da Justiça, a imensa maioria de presos no Brasil é de homens, 95\%, dos quais cerca de 70\% não completaram nem mesmo o ensino fundamental e $10,5 \%$ são analfabetos. O quantitativo de presos estrangeiros em todas as unidades da Federação chega a mais de 2 mil (MJ, 2006) e a população de mulheres presas passa de 25 mil (MJ, 2007).

O Ministério da Justiça (2006, online) afirma:

Embora a Lei de Execução Penal garanta ao preso o direito à educação, apenas 18\% da população prisional brasileira desenvolve alguma atividade educativa durante o cumprimento da pena. As estatísticas relacionadas aos presos que trabalham também são desanimadoras - $70 \%$ deles vivem na mais absoluta ociosidade.

Desta forma, a ressocialização pregada pela LEP implica novas políticas educacionais nos presídios, objetivando não comprometer a reinserção do detento à sociedade.

São muitas as razões para o baixo índice de oferta de ensino no sistema penitenciário[...] A educação nas prisões vem sendo realizada pelos estados de forma pouco sistematizada, muitas vezes baseada no voluntarismo ou dependente de iniciativas da direção de cada unidade prisional. Isso se deve à pouca aproximação entre as secretarias estaduais de educação e de administração penitenciária, de forma a coordenar programas voltados especificamente para a educação do preso. (Departamento Penitenciário Nacional, do Ministério da Justiça, 2008, online).

O ensino e o aperfeiçoamento cultural e intelectual nos presídios é muito limitado graças à grande evasão escolar dentro do Sistema e a falta de infra-estrutura necessária, isto é, a não disponibilização de local adequado, também a carência de material escolar e a não contextualização do conteúdo programáticos com a realidade carcerária.

De acordo com Frei Betto (apud KOTSCHO, 2003, p.41):

O sistema penitenciário, tal como ele existe na sociedade capitalista, principalmente aqui no Brasil, é extremamente cruel, não só porque confina fisicamente o homem, sem que esse homem possa compreender o problema da liberdade, senão em relação à sua locomoção física, mas ele destrói a subjetividade do homem, no sentido de não 
lhe oferecer nenhuma possibilidade de racionalização da situação em que se encontra.

Julião $(2007$, p. 3) expõe a sua crítica a respeito das prisões brasileiras:

O Sistema prisional brasileiro passa por uma crise sem precedentes. Por todo o país espalham-se evidências de um acelerado e perigoso processo de deterioração. As prisões são uma bomba-relógio que a sociedade resiste a enxergar, apesar da frequiência e da selvageria das rebeliões.

Perante este quadro alarmante que arrasa as instituições prisionais brasileiras, é indigno - para não dizer - indecente e repugnante, manter seres humanos dentro de celas superlotadas, sujas, malcheirosas, sem a mínima condição necessária para o cumprimento da Lei de Execução Penal. Julga-se que cerca de $30 \%$ da população das prisões poderiam estar cumprindo penas alternativas, porém, no país não chega a $15 \%$ de todos os casos. Para o Departamento Penitenciário Nacional, um terço desta população cometeu apenas crimes de furto, roubo e uso ou venda de drogas. Crimes contra a vida, como homicídios, caracteriza-se em cerca de $9 \%$ dos casos. Dessa forma, "estima-se que a reincidência da população carcerária no país esteja em torno de 50 a 80\%", conseqüência da "cultura da prisão" e da falta de investimento em penalidades alternativas e (re)educação social (JULIÃO, 2007, p. 26).

A ausência de políticas de atendimento ao preso ou ao egresso das prisões faz com que aqueles que se ressocializem o façam por conta própria, uma vez que o Estado não apresenta soluções concretas que abrangem a todos os (ex) presidiários.

Em artigo "Desabafo de um juiz", publicado no Jornal Diário Catarinense, Florianópolis/SC, no Editorial, em 17/09/2004, assinado pelo Dr. Jorge Luis Costa Beber, Juiz de Direito da $1^{\text {a }}$ Vara Criminal de Blumenau/SC, o mesmo assim se pronuncia, ao explicar as razões porque, por opção própria, resolvera deixar de atuar na área criminal:

Os direitos básicos de cidadania continuam esquecidos. [...] Não me sinto vencido ou derrotado. Apenas, como juiz, não me vejo encorajado a continuar condenando pessoas, jogando-as em celas mais do que abarrotadas, sem a menor perspectiva de recuperação. A sanção penal, aplicada neste contexto, segundo penso, perde a sua própria função, transformando-se unicamente em tormentoso castigo e fonte primária da crueldade que presos egressos desse sistema transferem para as vítimas, que somos todos nós.

Freire (1987, p.31) com propriedade afirma que “a 'ordem' social injusta é a fonte geradora, permanente, desta 'generosidade' que se nutre da morte, do desalento e da miséria'. Foucault (1998, p.221) assegura: 
As prisões não diminuem a taxa de criminalidade: pode-se aumentá-las, multiplicálas ou transformá-las, a quantidade de crimes e de criminosos permanece estável, ou, ainda pior, aumenta[...] Enfim a prisão fabrica indiretamente delinqüentes.

Já Castinglione (apud MUAKAD, 1998, p. 25) diz que a "prisão deve ter o mesmo objetivo que tem a educação da infância na escola e na família; preparar o indivíduo para o mundo a fim de conviver tranquilamente com seus semelhantes". 


\title{
4.2 LEITURA E LEITURA TERAPÊUTICA
}

\begin{abstract}
A leitura é fenômeno e ato. Como fenômeno, é o advento espontâneo de essências (lúdicas, romanescas, poéticas, entre outras) e como ato ela diz respeito às representações com as quais podemos refletir aquelas essências (Clarice Fortkamp Caldin).
\end{abstract}

Desde o surgimento da escrita e, sobretudo, após o advento da imprensa no século XV, a leitura passou a ser considerada o alicerce para o desenvolvimento e construção do saber, bem como para a realização pessoal.

Se hoje, ler um texto qualquer, apesar do analfabetismo ainda existir e persistir em muitos países, inclusive nos chamados países desenvolvidos, é tido como um ato simples e até natural, na antiguidade, saber ler era um privilégio de poucos. No período clássico, gregos e romanos consideravam a escrita e, por consequência a leitura, como sendo as bases para uma educação ajustada, visando o aperfeiçoamento intelectual, espiritual e físico, permitindo ao indivíduo maior respeito perante a sociedade, além de uma ascensão social. Na Grécia a leitura se limitava aos filósofos e aristocratas, já em Roma, garantia que patrícios alcançassem o direito de propriedade. Os gregos, ainda, garantiam que as bibliotecas eram como repositórios farmacêuticos para a alma, enquanto os romanos acreditavam que orações deveriam ser lidas para os doentes convalescerem sua saúde mental.

$\mathrm{Na}$ Idade Média, a Igreja era vista como a única detentora da cultura e do saber. Nos mosteiros se concentravam a quase totalidade dos livros e textos existentes até então; lá os textos eram lidos, avaliados e, após julgamento, copiados pelos monges e distribuídos exclusivamente aos que seguissem a vida religiosa. A Igreja considerava a leitura e a escrita sagrados, cabendo aos leigos unicamente escutá-los e memorizá-los, sem contrapor nenhuma objeção. O monopólio clerical permaneceu até meados do século XI, quando do aparecimento dos primeiros comerciantes e do aumento das zonas urbanas.

\footnotetext{
A imprensa proporcionou a pulverização do saber, pois disponibilizou às massas textos profanos e sagrados, antes acessíveis apenas a uns poucos. Com o livro, o saber é agora estruturado por uma rede de remissões onde o conceito, a abstração servem para condensar a memória e para garantir um domínio intelectual que a grande quantidade dos conhecimentos já coloca em perigo (LIMA, W., 2001).
}

Para os povos antigos, o aprendizado era alcançado sob austero ensino em que o indivíduo aprendia a ler pelo método analítico, ou seja, por meio de um progresso linear: primeiro se decorava o alfabeto; em seguida, se aprendia a soletrar; e só enfim, se lia palavras 
avulsas, até se alcançar capacidade para ler frases completas e maiores. Às mulheres se ensinava somente a leitura, acreditando-se que elas se tornariam perigosas caso soubessem, também, escrever.

Muito embora tenha decorrido séculos após os primeiros processos pedagógicos, hoje ainda se observa a prática do método engessado de ensino, no qual se privilegia o mecanicismo da "decoreba" de signos lingüísticos e prevalece o aprendizado produtor de analfabetos funcionais. A leitura é pouco vista como compreensão e destrinche das orações.

Martins (1994) afirma que depois de alfabetizadas, as pessoas tendem a se limitar a ler apenas pragmaticamente, por buscar alguma resposta ou solução. $\mathrm{O}$ ser humano parece não entender que a leitura traz o mundo para mais perto dele, o deixa mais autônomo, sem a necessidade de se "ler pelos olhos de outrem".

\begin{abstract}
Entre os séculos XVI e XVIII, surgem novas práticas da leitura, uma delas é a leitura silenciosa, quando a mesma passa do domínio público para o privado. Desse modo, se tornou possível ler sem ser em voz alta, prática até então impossível. Essa prática foi difundida entre os alfabetizados e, no século XIX, surge a distinção entre aqueles que são inaptos à leitura, por não saberem ler em silêncio, e aqueles que, possuindo a capacidade da leitura silenciosa, são conceituados como leitores. A leitura silenciosa contribuiu para inovar o trabalho intelectual, que se tornou um ato individual, além de permitir a intimidade com os livros (SILVA, 1981 apud ROSA, 2006, p. 23).
\end{abstract}

Surgia, a partir desse momento, um maior interesse das pessoas pelas bibliotecas, onde se poderia ler silenciosamente, absorver o texto, concentrando em seu conteúdo e refletir sobre o assunto estudado.

O fortalecimento da leitura no século XIX impulsionou a edição e impressão cada vez maior de novas obras literárias. Lajolo e Zilberman (1996, p. 18) completam:

Só por volta de 1840, o Rio de Janeiro, sede da monarquia no Brasil, passa a exibir alguns traços necessários para formação e fortalecimento de uma sociedade leitora: estavam presentes os mecanismos mínimos para a produção e circulação da literatura; como tipografias, livrarias e bibliotecas; a escolarização era precária, mas manifestava-se o movimento visando à melhoria do sistema; o capitalismo ensaiava seus primeiros passos graças à expansão da cafeicultura e dos interesses econômicos britânicos, que queriam um mercado cativo, mas em constante progresso.

O leitor, diante do texto, tem liberdade para aceitar ou não o que o livro lhe impõe. No entanto, tal livre-arbítrio tem seus limites estabelecidos pela própria prática da leitura. Para Chartier (1999), a leitura se caracteriza como eterna "apropriação, invenção e produção de significados" (p. 77), segundo o mesmo autor, a onipotência do leitor se restringe às 
possibilidades historicamente variáveis e socialmente desiguais, pois o tempo e os lugares mudam os objetos lidos e as razões para se ler.

[A leitura] muda muito, você viaja por um caminho, você quer que o escritor te
conduza e naquela viagem você vê vários mundos, várias opiniões e nem uma delas
te força a acreditar, você é que tem que escolher. É uma coisa fantástica... ela te
permite... ter um senso crítico, ter uma opinião formada... (OLIVEIRA, D., 2004, p.
5)

Poucos anos depois Ferreira (2003 apud MENDES, R., 2008, p. 63) corrobora o pensamento:

\footnotetext{
Na visão transacional da leitura tanto aquele que conhece como o que é conhecido se transformam no processo de conhecimento, a medida que foi lido é assimilado, passa por elaborações e reelaborações, estabelecendo-se assim um novo conhecimento e uma nova percepção da realidade exterior; a pessoa vai se modificando (valores, atitudes e comportamento).
}

Sabe-se que a leitura é "um processo de compreensão de expressões formais e simbólicas, não importando por meio de que linguagem. Assim, o ato de ler se refere tanto a algo escrito quanto a outros tipos de expressão do fazer humano" (MARTINS, 1994, p. 30), caracterizando-se igualmente como fenômeno de caráter histórico e determinando um relacionamento de tal modo histórico entre o leitor e o que é lido.

Larrosa (1996 apud MIRANDA, 2006, p. 89) acredita que "pensar a leitura como formação, implica pensá-la como uma atividade que tem a ver com a subjetividade do sujeito leitor; não só com que o leitor sabe, mas, também, com aquilo que ele é". A leitura deve ser observada como fenômeno capaz de formar e transformar, organizar e traduzir o que seja o ser humano. "A interação ocorrerá se o leitor se posicionar como 'cidadão do mundo', ou seja, integrando à 'aldeia global', com capacitação para o convívio social, político e cultural”.

Maria (1994, p. 175 apud ROSA, 2006) transmite à leitura o poder de esclarecimento e cultura, no qual o livro torna-se o transmissor principal do conhecimento: "Ler é uma experiência. Ler sobre uma tempestade não é o mesmo que estar em uma tempestade, mas ambas são experiências [...] A experiência na leitura produz sempre mais conhecimento sobre a própria leitura, de modo que aqueles que lêem muito sem dúvida tendem a ler melhor" (MARIA, 1994, p.175).

Martins (1994) ainda sintetiza o ato de ler em duas caracterizações:

1) Perspectiva behaviorista-skinneriana: leitura mecânica de signos e símbolos linguísticos, por meio do aprendizado de estímulo-resposta; 
2) Perspectiva cognitivo-sociológica: leitura abrangente, baseada em componentes sensoriais, emocionais, intelectuais, fisiológicos, neurológicos, culturais, econômicos e políticos.

Quanto mais o indivíduo ler, mais capaz estará para entender os desafios do mundo e do saber. De acordo com Lajolo (1986 apud ROSA, 2006, p. 24),

ler não é decifrar, como um jogo de adivinhações, o sentido de um texto. É, a partir do texto, ser capaz de atribuir-lhe significação, conseguir relacioná-lo a todos os outros textos significativos para cada um, reconhecer nele o tipo de leitura que seu autor pretendia e, dono da própria vontade, entregar-se a esta leitura, ou rebelar-se contra ela propondo outra não prevista.

A leitura vai além do texto (seja ele qual for) e começa antes do contato com ele. Ao defrontar o texto e o leitor, dá-se início ao processo de decodificação de plurisignificados relacionados à vivência de cada indivíduo. E é no pluralismo interpretativo que o tratamento biblioterapêutico se insere para propor mudanças no comportamento daqueles indivíduos que sofrem algum transtorno ou desequilíbrio.

$\mathrm{O}$ ato de ler tem sido usado através da história da humanidade no auxílio de pessoas que queiram criar um senso de identidade, que buscam crescimento pessoal ou até mesmo o bem-estar físico. A leitura surge de diversos contextos, desde os grupos, da família ou até mesmo do indivíduo isolado (ROSA, 2006, p. 26).

Dada a importância da leitura, a biblioterapia surge como método terapêutico baseado na interpretação de textos, compondo-se num sistema de sentimentos, valores e ações, buscando alcançar como resultado o equilíbrio, a harmonia, o lazer, mudança comportamental, afinamento cultural e educacional, desenvolvimento pessoal do indivíduo e, até mesmo, (re) inserção social e profissionalização.

Caldin (2005 apud MENDES, R., 2008, p. 60) apresenta o porquê do crescimento da biblioterapia relacionada aos benefícios da leitura:

\footnotetext{
A leitura do texto literário produz no leitor e no ouvinte um efeito de tranquilidade, concedendo à literatura a virtude de ser sedativa e curativa, proporcionando prazer e conforto, contribuindo para o bem-estar físico e mental das pessoas. A função terapêutica da leitura admite a possibilidade da literatura proporcionar a pacificação das emoções, partindo do pressuposto que toda experiência poética é catártica, e que a exteriorização de emoções produz uma reação de alívio da tensão nos pacientes.
} 


\title{
4.3 BIBLIOTERAPIA
}

Ao analisar a biblioterapia pretendeu-se verificar e compreender o que seja o uso da leitura como técnica terapêutica, expondo argumentos, considerações, representações, entre outros, atinentes ao tema. Neste sentido, faz-se uma abordagem, inicialmente, ampla e associativa, de modo a criar um delineamento referente ao assunto e à pesquisa.

Sempre é hora, seja para o auto conhecimento ou mesmo para resolver algum problema. Costumo dizer que a terapia vem para ajudar a resolver questões que você não consegue resolver sozinho (Olga Tessari).

A leitura já era considerada uma forma de curar doenças ou abrandar sintomas psicológicos de doentes mentais desde a antiguidade por povos ancestrais. Pereira (1996) certifica que os livros são formas de transmissão de informações e cultura por gerações. Evidencia, ainda, que a Bíblia já era usada, séculos atrás, como forma de conforto e cura espiritual.

Ferreira (2003, p. 36) declara que o uso da leitura, com objetivo terapêutico, existe desde o antigo Egito, no tempo do faraó Ramsés II, que colocou na frente de sua biblioteca a seguinte frase: "Remédios para alma". As bibliotecas egípcias estavam localizadas em templos denominados "casas de vida" e eram conhecidas como locais de conhecimento e espiritualidade.

Caldin (2001, p. 2) complementa:

\begin{abstract}
A relação entre psique humana e literatura não é nova. Foi, inicialmente, alicerçada pelas emblemáticas observações psicanalíticas de Freud sobre a escrita como arte poética desde os gregos até alguns de seus representantes modernos como Shakespeare e Dostoievski. Posteriormente, recebeu uma análise de Jung, que viu em Goethe, Spitteler, Nietzche, Blake e Dante personalidades criativas e transformadoras do mundo. Enfatizada, também, pela linhagem marxista com Vygostky na psicologia infantil ou com a atividade de Sartre entre a literatura e a filosofia existencial, essa relação foi se confirmando em todo o século XX.
\end{abstract}

Alexandre Silva (2005) revela que a biblioterapia tem seu surgimento atrelado à saúde pública ao longo da história. Pereira (1996 apud SILVA, A., 2005, p. 13) corrobora com mesmo pensamento: "Foi marcadamente dentro de hospitais que a experiência do uso de biblioterapia feita por biblioteconomistas, médicos, enfermeiros e, mais tardiamente, por psicólogos, teve início". 
O tratamento terapêutico usando a leitura como meio de libertação mental e relaxamento corporal, bem como a união entre ambos, ou seja, um equilíbrio entre corpo e mente sem entraves e em plena harmonia, também já era usado no século I por Fílon de Alexandria (filósofo grego de Alexandria, nascido provavelmente na Judéia entre 20 a.C. e 45 d.C., que interpretava a cultura helenista e narrativas bíblicas sob a ótica da alegoria e da filosofia grega).

Chama a atenção o fato de que na cultura hebraica a alma não apenas possui uma notável evidência, como também ela é assinalada, caracterizada pela linguagem, pela palavra pronunciada. Rosa (2006, p. 12) arremata: “O 'ser humano vivo' é um 'corpo falante', e o terapeuta é aquele que cuida da palavra que anima e informa o corpo. Para curar alguém é preciso fazê-lo falar e observar o que impede a palavra no corpo".

Freud, igualmente, pesquisou e avaliou a relação da palavra com a alma. Antes mesmo de valer-se do termo 'psicanálise', tão usado por ele, fez uso da expressão 'Seelenbehandlung' traduzida inicialmente para o português como sendo 'tratamento psíquico', entretanto especialistas afirmam que a melhor tradução seria 'tratamento da alma'. Tratamento psíquico significa [...] tratamento que tem origem na alma, tratamento -
de perturbações psíquicas ou corporais - com a ajuda de meios que agem primeiro e
imediatamente sobre a alma do homem. Tal meio é antes de tudo a palavra, e as
palavras são o instrumento essencial do tratamento psíquico. O profano achará, sem
dúvida, dificilmente concebível que perturbações mórbidas do corpo ou da alma
possam ser dissipadas pela 'simples' palavra do médico. Ele pensará que lhe
pedimos para acreditar em magia, no que não estará totalmente errado: as palavras
de nossos discursos cotidianos não são nada além de magia sem cor.
(FREUD, 1980, apud ROSA, 2006, p. 13).

Desse modo, baseando-se na abordagem logoterapêutica, isto é, por meio da terapia do discurso, das palavras, recebe o nome específico de biblioterapia, originada do grego biblion livro, e therapeia - tratamento, a técnica que usa matérias de leitura com objetivo medicamentoso ou curativo, como ferramenta de recuperação psíquica de indivíduos com transtornos, desordens emocionais ou apenas como auxílio relaxante e desetressante.

Biblio é a raiz etimológica de palavras usadas para designar todo tipo de material bibliográfico ou de leitura, e terapia significa cura ou restabelecimento. A Biblioterapia é vista como um processo interativo, resultando em integração bem sucedida de valores e ações. O conceito de leitura empregado neste processo interativo é amplo e inclui todo tipo de material, inclusive os nãoconvencionais.(ROSA, 2006, p. 16)

Miranda (1996 apud MIRANDA, 2006, p. 101) considera "a propriedade terapêutica, tanto individual quanto coletiva na leitura não apenas no sentido de 'curar', mas também 
prevenir, de orientar, de desenvolver o ser humano numa trajetória supostamente mais construtiva e edificante" como sendo inegável seu poder de mudança.

A Biblioteconomia como ciência responsável pelo uso e disseminação da informação através de serviços e produtos informacionais está diretamente vinculada à biblioterapêutica. Discute-se, então, quando do surgimento da biblioterapia na Biblioteconomia. Acredita-se que em 1877, quando Justin Winson, empregado da Universidade de Harvard, ao permitir que os estudantes da mesma universidade tivessem acesso às estantes e, também, ao liberar a circulação dos livros, tenha dado início ao serviço de referência em bibliotecas. Assim sendo, teria sido o marco inicial da biblioterapia na Biblioteconomia, pois, o serviço de referência surgia com a intenção de ajudar e dar assistência aos leitores. Ainda sobre o início da biblioterapia no serviço de referência em bibliotecas, observa-se que tal serviço foi aperfeiçoado em 1940 por Abraham Flexner - educador americano, pesquisador de métodos de ensino e defensor da reforma na educação médica que viveu entre 1866 e 1959 - criador de planos de estudo e leitura para grupos de indivíduos com dificuldade de aprendizado.

Pardini (2002, p. 3) afirma:

\begin{abstract}
A partir de 1904, a biblioterapia passa a ser considerada como um ramo da biblioteconomia. Há informações de que a biblioterapia floresceu durante o período da primeira guerra mundial, quando bibliotecários leigos, ajudaram a construir rapidamente bibliotecas nos hospitais do Exército. A partir da década de 20, vários artigos e relatórios foram publicados, inclusive um que merece destaque com o título "Biblioterapia para bibliotecários". Sempre houve uma grande dúvida: será que biblioterapia é "arte ou ciência"? Não sabemos! Mas sabemos que ela é discutida e aplicada desde a antiguidade.
\end{abstract}

Beatty (1962) rebate a discussão sobre a biblioterapia ser considerada arte ou ciência. Para o autor, a leitura é considerável, não importando, simples e unicamente, se é analisada ou contemplada como uma 'arte' ou como uma 'ciência'.

Bentes Pinto (2005) infere que a biblioterapia, apesar de ter sido utilizada já na Antiguidade como tratamento terapêutico, somente em 1916 ela tenha sido conceituada por Samuel McChord Crothers em um artigo referindo-se à biblioterapia como nova ciência, publicado na The Atlantic Monthly - periódico de literatura americano, fundado em Boston em 1957.

Do mesmo modo, Lima (2002) certifica que em 1931, adultos em liberdade condicional dos Estados Unidos foram alvos de projetos científicos de leitura, demonstrando o emprego da biblioterapia como apoio no processo de reinserção social dos ex-detentos. Outro exemplo de programas de leitura direcionada foi o projeto Grandes Livros, criado pela 
Universidade de Chicago em 1945, baseado na discussão orientada terapeuticamente dos textos de livros.

\begin{abstract}
Em 1970, Sclabassi escreveu um artigo e faz uma revisão da literatura em Biblioterapia classificando a pesquisa em quatro áreas profissionais: medicina geral (a técnica se volta ao campo médico, sendo aplicada por um bibliotecário do hospital ou por um bibliotecário em conjunto com outro profissional da área médica), psiquiatria (aplicada no tratamento de pacientes em hospitais e clinicas em conjunto com outras técnicas terapêuticas), educacional (usada para vários propósitos e em todos os níveis da educação), e corretiva (livros usados com delinqüentes por pesquisadores responsáveis da área). Sclabassi ainda categoriza a intervenção biblioterapêutica em quatro níveis: intelectual, social, emocional e comportamental. $\mathrm{A}$ autora levanta dois aspectos quanto à pesquisa em Biblioterapia. O primeiro referente ao termo biblioterapia e sua implicação a tratamento, porém, sendo utilizada também para propósitos de diagnóstico (bibliodiagnose) e de prevenção (biblioprofilaxia). As distinções entre os tipos não são claros na pesquisa sobre a técnica. O segundo problema, na visão da autora, recai nos trabalhos publicados, sendo, na sua maioria, descritivos ao invés de experimentais. (FERREIRA, 2003, p.39 apud ROSA, 2006, p. 21).
\end{abstract}

Segundo Vicente (2000 apud ROSA, 2006) a biblioterapia pode ser vista sob três concepções: a primeira incide na biblioterapia como ajuda ao processo terapêutico; a segunda consiste na biblioterapia como terapia própria; por fim, a terceira concepção vê a biblioterapia como regra, como prescrição para o desenvolvimento e crescimento pessoal.

Indo ao encontro do que seja caracterizado como biblioterapia, Bentes Pinto (2005, p. 9) conclui que "as concepções modernas acerca da leitura enfatizam que essa prática não pode ser entendida apenas como a decodificação de signos lingüísticos, mas também como uma prática social que contemple a produção de sentidos [...]" e se constrói multidisciplinarmente.

Rubin (1978), ao considerar o livro como material-objeto da biblioterapia, afirma que cada indivíduo perceberá sua leitura de modo distinto. No momento em que livro está sendo lido, ocorrem fenômenos psicológicos fundamentados em impressões externas ao organismo de cada um. Alguma mudança do ambiente de leitura ou do estado psicológico do leitor, o livro será percebido como elemento independente. O processo subjetivo psicológico desencadeado, então, é visto pelo leitor como um fenômeno evocado pelo objeto livro.

Considera-se, evidentemente, que a simples leitura de algum texto não se concretiza em biblioterapia, uma vez que para tanto deva haver um intercâmbio entre o indivíduo e a literatura/personagem, bem como entre indivíduo e o profissional especializado (bibliotecário, psicólogo ou mesmo um assistente social) na condução do melhor método de leitura para o bem do indivíduo/paciente. Ferreira (2003, apud NUNES; FRANCO, 2005, p. 7) completa: "A técnica utilizada com a palavra escrita para ser considerada biblioterapia deve estar 
centrada a mudança de comportamento através do autoconhecimento e utilizando as qualidades racionais e emocionais dos indivíduos que se submetem a ela".

\title{
4.3.1 BIBLIOTERAPIA: CONCEITOS, RELACIONAMENTOS E FINALIDADES
}

\begin{abstract}
Exibir termos e definições não corresponde, necessariamente, a dominarmos os conceitos a eles correspondentes. Quem tem segurança de que os conceitos que repetimos são adequados, úteis e significativos? (Jaime Paviani e Silvio Botomé).
\end{abstract}

De acordo o Webster's Third New International Dictionary (apud PEREIRA, 1996), a biblioterapia está caracterizada como uso de material de leitura selecionado como coadjuvante ou auxílio terapêutico em medicina e psicologia, também, como guia na solução de problemas penais através da leitura conduzida.

Alice Bryan (apud CALDIN, 2001, p. 2), define:

\begin{abstract}
Biblioterapia é a prescrição de materiais de leitura que auxiliem a desenvolver maturidade e nutram e mantenham a saúde mental. Inclui na biblioterapia; romances, poesias, peças, filosofia, ética, religião, arte, história e livros científicos. Apresenta como objetivos: permitir ao leitor verificar que há mais de uma solução para seu problema; auxiliar o leitor a verificar suas emoções em paralelo às emoções dos outros; ajudar o leitor a pensar na experiência vicária em termos humanos e não materiais; proporcionar informações necessárias para a solução dos problemas, e, encorajar o leitor a encarar sua situação de forma realista de forma a conduzir à ação. Sua teoria é de que os indivíduos são personalidades integradas e, portanto, a criança deve ser vista como um todo e educada emocional e intelectualmente. Vê a literatura ficcional como um meio de afetar o ajustamento total do indivíduo. Recomenda a cooperação entre bibliotecários e psicólogos, pois entende a biblioterapia como um dos serviços da biblioteca.
\end{abstract}

L.H. Tweffort (apud CALDIN, 2001, p. 3), conceitua

\begin{abstract}
biblioterapia como sendo um método subsidiário da psicoterapia; um auxílio no tratamento que, através da leitura, busca a aquisição de um conhecimento melhor de si mesmo e das reações dos outros, resultando em um melhor ajustamento à vida. Lista como objetivos da biblioterapia: introspecção para o crescimento emocional; melhor entendimento das emoções; verbalizar e exteriorizar os problemas; ver objetivamente os problemas, afastar a sensação de isolamento; verificar falhas alheias semelhantes às suas; aferir valores; realizar movimentos criativos e estimular novos interesses. Recomenda livros de higiene mental e classifica-os de acordo com as fases da vida: infância, adolescência e idade adulta.
\end{abstract}

Em contrapartida, para Rosa Mendes (2008, p. 67) a biblioterapia não tem relação alguma com a psicoterapia, visto que na biblioterapia o próprio texto é que atua como terapeuta. "Além da literatura, os comentários, os gestos, os sorrisos, os encontros são 
também terapêuticos à medida que fornecem a garantia de que não estamos sozinhos" (CALDIN, 2001, p. 8).

Nunes e Franco (2005, p. 4) acreditam que o termo 'biblioterapia' restringe muito o material utilizado aos livros e diante do desenvolvimento dos suportes de informação, o vocábulo mais adequado ao tratamento biblioterapêutico seria 'literapia' - literatura e terapia - desta forma daria um foco mais literal-imaginativo à nomenclatura. Entretanto, não há um aceitamento da possível nova terminologia por parte dos biblioterapeutas e pesquisadores.

Explorando o enfoque da literatura ficcional, Matthews e Londsdale (1992 apud CALDIN, 2001, p. 4) creem que na biblioterapia o indivíduo que se deixar tratar pelo método biblioterapêutico deve procurar perceber as afinidades entre ele o personagem da literatura, com o intuito de aperfeiçoar e compreender melhor suas emoções e desejos, alcançando resultados benéficos para o seu bem-estar.

Pereira (1989), em sua dissertação de mestrado sugere que a biblioterapia possa ser usada em benefício da qualidade de vida de deficientes visuais, objetivando com isso oferecer a eles mais uma maneira de adaptação e alívio aos conflitos por eles enfrentados. "É indubitável a contribuição da biblioterapia para pessoas de características as mais variadas da sociedade. Sendo de grande valia para pessoas com deficiências ou afetadas com problemas de saúde. Essa contribuição reflete-se notadamente nos aspectos emocionais.” (Id., 1989, p. 22).

Pereira (1996, p. 58) objetivando delinear a biblioterapia como ação efetiva em seus aspectos a subdivide em três tipos:

a) Biblioterapia Clínica: Tratamento feito em grupo de pessoas (voluntários ou não) com problemas emocionais, praticada em instituições privadas ou da comunidade e usando a literatura imaginativa dando ênfase nas visões e reações do paciente.

b) Biblioterapia Comportamental: Refere-se ao tipo de biblioterapia em que o bibliotecário é o líder na promoção do crescimento pessoal do leitor/paciente. Faz-se o uso da literatura imaginativa e didática em pessoas consideradas normais, mas que sofram com dificuldades individuais como morte, preconceitos, confinamentos ou situações de crise. A meta desta tipologia é o melhoramento comportamental e a autorrealização.

c) Biblioterapia Institucional: Tipologia considerada rara atualmente, apesar de existirem projetos semelhantes, na qual se usa a literatura de maneira didática. $\mathrm{O}$ médico e o bibliotecário, trabalhando em conjunto, prescrevem 
livros para doenças específicas dos leitores/pacientes, que são tratados individualmente. $\mathrm{O}$ objetivo principal é a recreação e informação do leitor/paciente.

A autora Clarice Fortkamp Caldin (2001, p. 5), bibliotecária do estado da Santa Catarina e exímia conhecedora da leitura - função terapêutica; leitura - função social e leitura - função pedagógica, afirma que na "biblioterapia as discussões em grupo favorecem a interação entre pessoas, levando-as a expressarem seus sentimentos e receios, dúvidas e anseios. No qual o homem não está mais solitário para resolver seus problemas, ele os partilha com seus semelhantes em troca de experiência e valores". Caldin ainda acredita que a biblioterapia possa auxiliar no desenvolvimento intelectual do ser humano dinamizando a visão de mundo e estimulando o tratamento espiritual.

Para Ouaknin (1996, p. 198), "a biblioterapia é primariamente uma filosofia existencial e uma filosofia do livro", acentuando que o homem é "ser dotado de uma relação com o livro". Com isso, o ser humano começa a entender a si mesmo do mesmo modo que percebe mais facilmente o que está escrito nos textos. O indivíduo ao ler e compreender um livro ou uma história de cunho literário se introduz em seu enredo, fazendo parte dele. A junção perfeita entre a definição prática do que está escrito no texto e o seu entendimento subjetivo se faz presente na interpretação.

Bentes Pinto (1995 apud BENTES PINTO, 2002, p. 9) entende

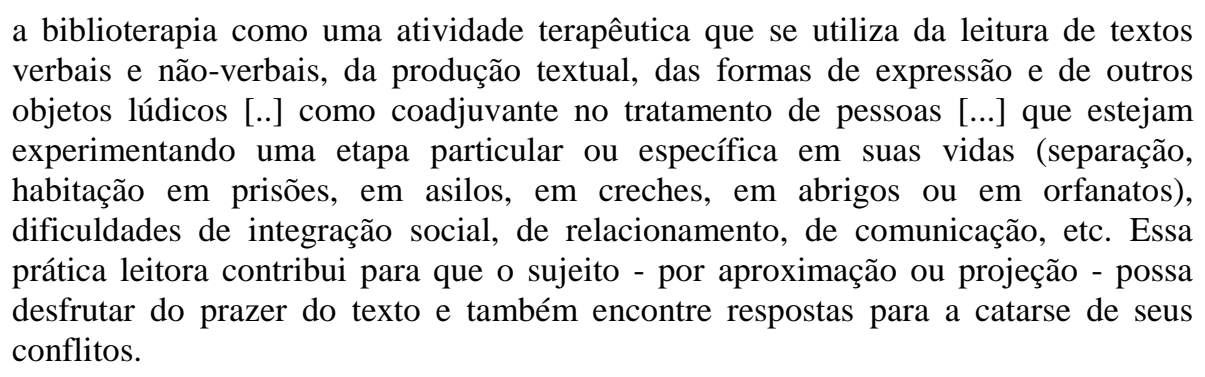

A biblioterapia foi usada inicialmente em tratamentos de pessoas com deficiências mentais "tendo como objetivo fazer com que os pacientes modifiquem seu comportamento visando à solução ou melhora de seus problemas" (PEREIRA, 1989, p. 57), contudo novas indicações do livro como forma de tratamento de patologias foram surgindo, demonstrando que a biblioterapia poderia assessorar ou conduzir satisfatoriamente o melhoramento de doentes. Um exemplo é o tratamento biblioterápico voltado para o desenvolvimento pessoal em que o desígnio é levar o indivíduo a um crescimento intelectual por meio do amparo literário. 
Desta forma, Caldin (2001 apud NUNES; FRANCO, 2005, p. 8) descrevem que as fases que envolvem as ações terapêuticas da biblioterapia são compostas por:

- Catarse (pacificação, serenidade e alivio das emoções) é a função libertadora da arte, onde a leitura de textos literários exerce o poder de purificação psicológica e intelectual;

- Humor (ação do super ego sobre o ego a fim de protegê-lo contra a dor) o humor é a rebelião do ego contra as circunstancias adversas transformando o que poderia ser objeto de dor em objeto de prazer;

- Identificação: processo psicológico pelo qual um sujeito assimila um aspecto, uma propriedade, um atributo de outro e se transforma, total ou parcialmente, seguindo o modelo desse outro;

- Introjeção: estritamente ligada à identificação, consiste na absorção do sujeito de fora para dentro;

- Projeção: transferência aos outros de nossas idéias, sentimentos, intenções, expectativas e desejos. O sujeito expulsa de si e localiza nos outros, qualidades, sentimentos e desejos;

- Introspecção: observação de por uma pessoa de seus próprios processos mentais, o individuo é levado a refletir sobre os seus sentimentos.

Caldin (2001) ao fazer uso de vocábulos como 'catarse', 'introjeção', 'introspecção' cria uma ponte entre diferentes campos de conhecimento, ou seja, ciências como Filosofia, Psicologia e Biblioteconomia, consideradas remotas na aplicação de seus cabedais científicos passam a interagir não somente na acepção de seus termos, mas também em algum pressuposto comum: o bem-estar do indivíduo.

No que tange aos objetivos, Katz (1992 apud NUNES; FRANCO, 2005, p. 9) acredita que as metas da biblioterapia são:

Ampliar a compreensão e conhecimento de um problema ou diagnostico; Incentivar habilidades sociais e reforçar comportamento aceitável e corrigir ou remover comportamento nocivo ou confuso; Dar orientação espiritual ou inspirativa; Desenvolver um senso de pertencimento, o qual por sua vez ajuda o paciente a se sentir melhor emocionalmente; Explorar metas e valores pessoais; e proporcionar uma oportunidade para catarse e "abreaction".

Nunes e Franco (2005, p. 9) ainda complementam a ideia sobre os objetivos da biblioterapia fazendo uma ressalva sobre o emprego descuidado da biblioterapia por parte do profissional que a utilizar: "[...] deve-se atentar para a escolha do tipo de biblioterapia que será utilizado, para isso se faz necessário um estudo do paciente/leitor, tendo em vista obter conhecimento de quais problemas e necessidades informacionais enfrentados por cada indivíduo".

$\mathrm{Na}$ década de 30, Louise Rosenblatt, professora de literatura inglesa e criadora da teoria resposta do leitor (Reader-Response Theory), ajuíza a biblioterapia como subsídio a adequação social e individual. A literatura estimularia a reflexão e regularia o indivíduo em 
relação aos conflitos pessoais e interpessoais. Com isso, Rosenblatt, divide a biblioterapia como método de cura ou prevenção, de acordo com seus objetivos. Ao buscar a cura, pretende--se levar o indivíduo a compreender seus sentimentos, libertá-lo de seus medos e aumentar a sociabilidade. Já na prevenção, intenta acautelar perturbações nervosas e condicionar as desordens subjetivas.

William C. Menninger, psiquiatra norte-americano e pesquisador de tratamentos de distúrbios comportamentais, por volta da década de 30 do século passado já afirmava que a biblioterapia provocaria novas emoções, conforto e autoidentificação. A leitura didática faria com que o indivíduo adquirisse conhecimento e autorrealização.

Seitz (2000) explica que em unidades de ensino como escolas ou até mesmo em centros de reeducação juvenil, a biblioterapia pode ser usada como meio concreto e eficaz para a modificação de condutas reprováveis cometidas pelos jovens; já em instituições de amparo a idosos, como asilos e abrigos, a terapêutica literária influencia no equilíbrio psicológico e, também, no relacionamento social dos idosos; no caso de pessoas com dificuldades ou deficiências físicas permanentes, a biblioterapia facilita a tolerância e a aceitação mental em situações ou fatos irremediáveis ligadas à sua deficiência ou dificuldade.

Alves (1982 apud CALDIN, 2001) considera a biblioterapia nas prisões como indispensável à reeducação dos detentos. Avalia que a leitura torna-se um aliado muito importante no combate ao estresse ocasionado pelo confinamento e por situações degradantes dos espaços prisionais. Acrescenta, também, que juntamente aos modelos tradicionais de ocupação do tempo do preso - trabalho e lazer - a leitura também deve ser incluída. Para tanto é necessário o acompanhamento de um bibliotecário assessorado por um psicólogo e o assistente social.

Rosa (2006, p. 33) explica que a biblioterapia pode ser empregada em cinco domínios distintos:

- Pedagógico: o livro como instrumento de desenvolvimento intelectual infantil e juvenil. Segundo Raton (1975, p. 205 apud ROSA, 2006, p. 34) "alguns professores fazem atualmente uso de livros não didáticos para desenvolver atitudes preparando o aluno para enfrentar os problemas da vida moderna".

- Clínico: na medicina, a biblioterapia pode ser conduzida por um médico auxiliado por um bibliotecário ou vice-versa, desde que os profissionais se empenhem na aplicação, condução e na busca de resultados benéficos ao paciente/leitor. Vasquez (1989 apud ROSA, 2006, p. 35) acredita que a biblioterapia dentro de hospitais seja elemento essencial para o tratamento de 
pessoas que permaneçam internadas por longos períodos. "A leitura pode ser usada na profilaxia, reabilitação e terapia propriamente dita" (Ibid.).

- Psiquiátrico: na psiquiatria o livro exerce a função de auxiliar em diversas fases do tratamento psíquico. A biblioterapia ganha destaque no tratamento preliminar de doentes com dificuldades de comunicação e expressão, sendo, também, relevante no tratamento de dependentes químicos.

- Geriátrico: entre os idosos, a biblioterapia pode ser usada como redutor de ansiedade, tristeza e inquietações senis. Vasquez (1989 apud ROSA, 2006, p. 37) listou as quatro principais metas da biblioterapia para idosos: Enriquecimento pessoal; Visão interna e compreensão do próprio ser; Percepção social; Conhecimento da realidade externa ao indivíduo.

- Correcional: campo em que a biblioterapia é utilizada visando a recuperação de indivíduos criminosos, jovens ou adultos, geralmente detentores de conflitos emocionais e sociais.

A leitura pode ser aproveitada na atenuação e/ou solução da ansiedade, inquietação e de sofrimentos diversos, conduzindo manifestações agressivas para atividades desestressantes.

Segundo Caldin (2001 apud ROSA, 2006, p. 34) em 1982, Hess utilizou o livro em prisões brasileiras como objeto de reeducação social dos detentos.

Para Hasse (2004 apud ROSA, 2006, p. 34), "a Biblioterapia tem sido aplicada desde o início do século XX, evoluindo na sua abordagem até nos dias atuais. O uso da técnica pode ser visto também em prisões [...] e com uma população bastante diversificada".

De modo analógico a Pereira (1996) quando este propõe programas de leitura para portadores de deficiência visual, e apoiando-se nas especificações de Rosa (2006) sobre os usos da biblioterapia em diferentes ramos de aplicação, somos levados a crer que o emprego da técnica biblioterapêutica correta, no caso de Centros Penitenciários, atrelada ao lazer e à informação utilitária, a biblioterapia possa criar oportunidade para adequamento social, pedagógico e bio-psíquico dos detentos. Contribuindo, com isso, para com o processo de reciclagem e ressocialização. 


\title{
4.3.2 O BIBLIOTECÁRIO E A BIBLIOTERAPIA
}

\begin{abstract}
Abordar o tema campo de atuação, tanto para o profissional bibliotecário, como para qualquer outro, não é simplesmente apresentar um elenco de tarefas concernentes ao domínio; muito pelo contrário, implica, antes de tudo, perceber que cada profissão está vinculada ao saber, ao saber-fazer e também a um fazer-saber (Virginia Bentes Pinto).
\end{abstract}

A Biblioteconomia, assim como todas as ciências, também foi afetada pelas alterações contemporâneas que atingem a sociedade. Transformações ocasionadas por gigantescos e rápidos desenvolvimentos tecnológicos. O bibliotecário, figura-chave no ambiente em que atua e nas responsabilidades a ele incumbidas, deve ter consciência da sua importância perante a sociedade, cônscio, outrossim, que é um agente de mudanças. Pardini (2002 apud BRAGA; SANTOS, 2006) compara a profissão de um bibliotecário com uma árvore, "onde do seu tronco saem muitas ramificações, mas o fruto é único e próprio dela”.

Assim, diante das possibilidades de atuação e das mudanças globais, Pereira (1996) afiança que o profissional bibliotecário deva quebrar o paradigma de ser considerado por décadas como meros catalogadores e classificadores de livros. Servindo apenas como elo entre o livro e leitor, subtraindo sua importância frente ao desenvolvimento informacional.

Reis e Carvalho (2007, p. 6) declaram:

\begin{abstract}
A profissão do bibliotecário está fundamentada em duas vertentes para exercer o seu papel social. A primeira delas é a competência técnica e administrativa concernente à informação (classificar, catalogar, disseminar numa linguagem acessível ao usuário). A segunda é atrelada à responsabilidade de zelar e fazer compartilhar a herança do exercício à cidadania, trabalhando com a informação, levando-a àqueles que dela necessitam.
\end{abstract}

Ortega y Gasset (2006) já afirmava que a arte de disseminar a informação atribui ao bibliotecário a função de ser um facilitador entre o livro e o leitor. Com isso, ao exercer a papel de biblioterapeuta o profissional bibliotecário colabora não só para um melhoramento psicológico do indivíduo, como também para a educação moral, formal e cultural.

\footnotetext{
O papel do biblioterapeuta é cuidar do fôlego da vida. Permitir que a pessoa respire, isto é, que desbloqueie suas tensões, que desabroche, que desate os nós que travam a livre circulação do sopro. O biblioterapeuta vale-se, portanto, da palavra, da conversa, do diálogo (Lucas et al, 2006 apud MENDES, R., 2008, p. 64).
}

Sales (2004, p. 2) faz uma relação entre o papel social e de gestor informacional do bibliotecário na melhoria da qualidade de vida do indivíduo: "Por se tratar de um profissional 
que trabalha com produção e gestão da informação, suas atividades têm uma potencialidade significativa de contribuir na melhoria da qualidade de vida social [...]”.

A biblioterapia exige o acompanhamento terapêutico, por isso, geralmente, o biblioterapeuta é um profissional da Biblioteconomia - podendo ser da área de saúde, psicologia, serviço social, educação e arte, ou mesmo um bibliotecário com apoio ou em apoio a estes profissionais - que indica material específico para dar assistência a uma pessoa, um grupo ou a uma instituição, no tratamento, acompanhamento ou prevenção de um problema físico ou psicológico.

Apesar das divergências em relação à data específica em que a biblioterapia passou a ser considerada uma ramificação da Biblioteconomia, visto que Pardini (2002) considera ter sido por volta de 1904, em contrapartida, Seitz (2000) reputa ter sido em 1914, os especialistas e estudiosos julgam de grande relevância a participação do bibliotecário em todo o decurso biblioterápico.

[...] Mas até hoje ainda há discussão sobre sua aplicação por bibliotecários. Alguns autores afirmam que cabe ao bibliotecário apenas a seleção do material. Outros concordam que os bibliotecários estão preparados para aplicar a Biblioterapia, sendo necessário apenas um treinamento especial. (SEITZ, 2000, p. 22 apud SILVA, Alexandre, 2005, p. 23).

O biblioterapeuta é um contador de histórias e antes de tudo um leitor atento, com capacidade de interferir no universo do paciente; aprende a estrutura de enredo deste e fornece paradigmas, através de textos, com o objetivo de alterar o encaminhamento da história pessoal em questão. Todavia, é de grande relevância que o biblioterapeuta deva conhecer os livros e os leitores, também, os efeitos de se colocar os dois juntos. Tendo como referência as leis de Ranganathan (The Five Laws of Library Science, 1931), em especial, a segunda lei - Todo leitor tem seu livro - o biblioterapeuta deve partir da premissa que o leitor deve ser observado e, só então, selecionado o material de literatura de acordo com seu perfil.

Em 1951 a University of Illinois nos Estados Unidos cria o Department of Library Instruction and Advisement, implantando a educação geral, instrução de biblioteca e um conselho estudantil na universidade. Desde então, deu-se origem ao termo 'BibliotecárioConselheiro' fazendo referência aos bibliotecários experientes, bem treinados e com personalidade de liderança que "deveriam ser capazes de fazer muito para encorajar os leitores a 'aplicar livros para si próprio' através da extensão dos tipos existentes de serviços bibliotecários" (PEREIRA, 1996, p. 48). 
Pereira (1996 apud SILVA, Alexandre, 2005) divide as responsabilidades da aplicação da biblioterapia entre bibliotecários e psicólogos. Para a autora, as duas ciências deveriam tratar sobre o tema concomitantemente buscando o seu desenvolvimento.

Menninger (apud LIMA, S., 2002) lembra que o médico deveria indicar o conteúdo literário e organizar um roteiro semanal de leituras determinadas para posterior avaliação; já ao bibliotecário delega-se a missão de ajuda aos indivíduos, a transmissão do conhecimento pessoal sobre a obra indicada e a elaboração de relatórios sobre "êxitos de comentários dos pacientes com relação às leituras".

Hannigan (1962 apud LIMA, S., 2002) classifica o papel do bibliotecário como o de um farmacêutico; corroborando com as prescrições médicas sobre os livros indicados e, em certa medida, responsável por sugestões de leituras adjacentes e complementares, assim como a responsabilidade da discussão com os pacientes sobre os textos indicados. Ressaltando que, geralmente, o médico não está interessado na biblioterapia, ficando na dependência que o bibliotecário seja não só o 'farmacêutico', mas também o biblioterapeuta.

Elser (1982 apud PEREIRA, 1996), fala sobre duas qualidades básicas do bibliotecário como agente terapeuta: como qualidade inicial e essencial, o biblioterapeuta deve valorizar as pessoas como indivíduos e como seres humanos, mostrando-lhes interesse e motivação não somente por ajudá-los, como também, pelos sentimentos e pela compreensão do assistido; a segunda qualidade essencial é a destreza no ato de comunicar-se.

Kinney (1962 apud PEREIRA, 1996) aponta os predicados ideais para o bibliotecário que se dedica à biblioterapia: o biblioterapeuta deve ter "estabilidade emocional, bem-estar físico e personalidade" sociável. Para Kinney, o biblioterapeuta não pode ater-se a preconceitos, deve ser um bom observador, saber escutar e doutrinar sua conduta mental, dirigindo suas emoções na ajuda ao próximo. Como profissional, necessita "assumir a responsabilidade pela seleção do material de leitura", baseando-a em fatores culturais, físicos e, sobretudo, emocionais do leitor.

Pardini (2002, p. 9) conclui:

\begin{abstract}
O bibliotecário, assim como todo ser humano, merece e deve praticar a biblioterapia para aliviar as suas tensões diárias. Familiarizar-se com o livro não apenas como um objeto de trabalho, mas com as letras que formam frases significativas e encante momentos do seu dia. Desta forma, estará ao mesmo tempo recebendo e transmitindo experiências, que o levará num processo de crescimento mútuo, através da leitura, gerada pelo efeito deste encontro.
\end{abstract}

Na biblioterapia o indivíduo é levado a refletir sobre sua relação com o ambiente em que frequenta ou habita, observando suas atitudes, sentimentos e como ele é afetado 
(reciprocamente) pelo ambiente. Por isso, Pereira (1996) ajuíza que o modo mais acertado de um bibliotecário abordar a biblioterapia é tratando-a "como atividade recreacional e ocupacional" (p. 51), deixando de lado a visão especificamente terapêutica, assim os resultados benéficos surgiriam do mesmo modo e com menos 'pressão' psicomédica. 


\subsection{BIBLIOTECAS DE ESTABELECIMENTOS PRISIONAIS}

“[...] contribuir para a recuperação social do preso e a melhoria de suas condições de vida, mediante a elevação do nível de sanidade física e mental, o aprimoramento moral, o adestramento e o oferecimento de oportunidade de trabalho [...]" (FUNAP).

As prisões nasceram com intuito inicial de punição e humilhação, com o passar dos tempos seu conceito transformou-se passando a ser um local que, apesar de ser considerado, no Brasil, mero depósito de presos, intencionam punir o indivíduo que tenha infringido a leis e ressocializá-lo para o regresso à sociedade. Assim, as bibliotecas de estabelecimentos prisionais, quando existentes, exercem um papel de extrema importância nesse contexto de ressocialização do preso.

Primeiramente, como Alveirinho e Lousada (2006) indicam, deve-se fazer um esclarecimento sobre a heterogeneidade entre bibliotecas especiais e bibliotecas especializadas. Estas, como o próprio nome assinala, têm um aspecto especializado, seja ele pelos profissionais que lá trabalham, seja pelos assuntos, temas exclusivos que elas oferecem. Podendo ser elas bibliotecas jurídicas, médicas, informáticas, financeiras, geográficas, entre outras. Já as bibliotecas especiais diferenciam nitidamente pelo público atendido, não tanto por seus conteúdos, estando necessariamente pertinentes às pessoas com necessidades especiais, ou seja, pessoas com dificuldades físicas, mentais, culturais, hospitalizadas e presas. Por isso, as bibliotecas especiais necessitam de profissionais que desenvolvam serviços especializados que vão ao encontro das dificuldades dos necessitados.

\footnotetext{
A assistência ao preso e ao internado é dever do Estado, objetivando prevenir o crime e orientar o retorno à convivência em sociedade. 'Essa é a redação do artigo 10 da Lei de Execução Penal. No art. 21 da Lei 7.210/84 prevê que: 'em atendimento às condições locais, dotar-se-á cada estabelecimento de uma biblioteca para uso de todas as categorias de reclusos, provida de livros instrutivos, recreativos e didáticos. Conforme estabelece o artigo 205 da Constituição Federal, "a educação, direito de todos e dever do Estado e da família, será promovida e incentivada com a colaboração da sociedade, visando ao pleno desenvolvimento da pessoa, seu preparo para o exercício da cidadania e sua qualificação para o trabalho", e o art. $208, \S 1^{\text {o }}$, da Carta Magna determina que o acesso ao ensino obrigatório e gratuito é direito público subjetivo. (SANCHES, 2008, online).
}

Sanches (2008) lamenta que a biblioteca nas prisões faça parte de uma conjuntura recente no Brasil, mesmo prevista na LEP em seu artigo 21, enquanto elemento determinante no processo de ressocialização dos encarcerados. A autora complementa seu ponto de vista ao 
considerar deplorável o fato de que o papel da biblioteca prisional ter sido relegado para segundo plano pelas autoridades da Administração Pública.

A International Federation of Library Associations and Institutions (IFLA) Federação Internacional de Associações e Instituições Bibliotecárias - tida como organização internacional que busca o melhoramento dos serviços biblioteconômicos, orientou em seus trabalhos Guidelines for library serviçes to prisoners (1995), Library Standards for Adult Correctional Institutions (1997) e Guidelines for Prison Libraries (1997) as diretrizes internacionais que a biblioteca para presos deveria seguir. Essas diretrizes servem como parâmetros para a elaboração de políticas governamentais nacionais que desejam implementar as referidas bibliotecas em estabelecimentos prisionais. Servem ainda como princípios para os direitos fundamentais dos reclusos na esfera literária, da aprendizagem e do acesso à informação.

A Declaração Universal dos Direitos do Homem (1948 apud ALVEIRINHO; LOUSADA, 2006) prega que a justiça criminal e de reclusão nas sociedades modernas deva ser praticada mais humanamente e de maneira mais esclarecida, alterando suas políticas punitivas para políticas de educação, reabilitação e utilização construtiva do tempo. Desta forma, a biblioteca prisional adquire relevância no espaço penitenciário, oferecendo aos presos informação útil, apresentando a oportunidade de aperfeiçoarem habilidades literárias, de atingirem os seus interesses culturais e de aprendizado, abrindo, com isso, uma janela para mundo exterior.

Contudo, é também de salientar que estes serviços especializados, desenvolvidos para dar resposta às necessidades especiais de um público utilizador heterogêneo, ultrapassam a prática profissional biblioteconômica. Ou seja, a implementação e manutenção destes serviços requer um grande envolvimento por parte dos bibliotecários no contexto social específico das comunidades desfavorecidas. (ALVEIRINHO; LOUSADA, 2006, p. 8)

Entre 1991 e 1994, a Organização das Nações Unidas para a Educação, a Ciência e a Cultura (UNESCO), partindo do propósito de que "o direito a uma educação básica nas prisões é um requisito indispensável para alcançar o objetivo reconhecido internacionalmente de garantir um nível básico de educação para todos" (UNESCO, 2002, p.1), promoveu, por solicitação do Conselho Econômico e Social das Nações Unidas (ECOSOC), um plano de averiguação e promoção da educação básica nos instituições prisionais, resultando, em 1995, em um compêndio que analisa o problema da educação nas prisões. 
O ECOSOC determina na Resolução n 20/1990 de 24 de maio de 1990 que "todos os reclusos devem gozar de acesso à educação, com a inclusão de programas de alfabetização, educação básica, formação profissional, atividades recreativas, religiosas e culturais, educação física e esportes, educação social, ensino superior e serviços de bibliotecas [grifo nosso]”.

As bibliotecas de estabelecimentos prisionais têm um papel essencial na organização da educação permanente na prisão, não apenas como serviço de distribuição de livros e de conselhos, mas tornando-se locais de cultura e de apoio à formação. Macri e Salazar (2005) garantem que estas bibliotecas podem desempenhar função pedagógica, bem como informar à população carcerária sobre saúde, trabalho, além de prepará-los para o egresso e o acolhimento dos familiares, especialmente as crianças, nos dias de visita.

Eiras (2007, p. 5) completa: "Independentemente das suas especificidades de funcionamento as bibliotecas de estabelecimentos prisionais apresentam-se como espaço de informação, cultura e lazer, tal como qualquer outro tipo de biblioteca".

Torna-se necessário que as bibliotecas prisionais estejam atentas aos gostos, relações culturais com o exterior, modelos seguidos, sonhos e objetivos, dificuldades e escapismos dos detidos, para que após a análise inicial se busque ajudá-los indicando o melhor referencial literário.

Marcos Jefferson (detento da Penitenciária Compacta de Avanhandava, SP apud MIRACELLY, 2005) após ter lido 'Os Sertões' de Euclides da Cunha, põe fim a crença que o presidiário não se interessa por literatura, mas sim, apenas, por revistas masculinas de mulheres nuas: "O contato com os livros modifica a personalidade dos sentenciados porque temos oportunidade de conhecer o mundo e outras culturas só de passar as páginas".

A IFLA (1999) avalia que geralmente os presos têm o mesmo interesse por certas leituras e as mesmas necessidades de informação que as pessoas livres; entretanto eles não têm, em sua quase totalidade, o desejado acesso às bibliotecas ou à informação. Pesquisas demonstram que eles estão ainda mais marginalizados, visto que há uma alta proporção de analfabetos e, também, uma grande quantidade daqueles que sofrem de transtornos emocionais ou psíquicos, além de pouca capacitação profissional.

Perez-Pulido (1997 apud JOHN, 2004, p. 55), descreve que o início dos planejamentos de leitura nas prisões ocorreu em 1870, após o Congresso Nacional de Prisões, em Cincinatti, nos Estados Unidos. Conforme a autora, "a partir desse momento, a educação passa a ser uma parte integral das técnicas de reabilitação e inserção" dos detentos. A autora ainda descreve que em 1915 a American Library Association (ALA) lançou as primeiras normas para bibliotecas em prisões americanas. Atualizadas em 1981, as normas, definiram o "serviço 
bibliotecário das prisões como um suporte e uma oportunidade para o programa total de reabilitação".

Garcia-Perez (2001 apud JOHN, 2004, p. 59) explica resumidamente a situação internacional e as características das bibliotecas de estabelecimentos prisionais nos Estados Unidos e em países europeus:

\footnotetext{
Na Noruega, a biblioteca prisional é considerada uma extensão da biblioteca pública; na Grã-Bretanha, é comum que a biblioteca pública empreste ou doe lotes de livros renováveis a cada quatro ou oito semanas; na França, muitas bibliotecas prisionais têm firmado acordos com instituições e associações públicas e privadas para melhorar acervo e funcionamento; na Holanda, existem bibliotecas em prisões há mais de 150 anos e nos anos 1980 foi iniciada a automatização das mesmas; e nos Estados Unidos, possivelmente é único país que coexistem, junto com bibliotecas de prisão, as 'bibliotecas jurídicas'. Isto se deve ao direito civil e constitucional do cidadão poder fazer sua própria defesa nos Tribunais daquele país.
}

Referindo-se ao conteúdo das instituições bibliotecárias, Carvalho (1965) avalia que a coleção das bibliotecas de estabelecimentos prisionais deva incluir materiais de direito, antropologia, sociologia, religião, auto-ajuda, romances, obras de referência, jornais e revistas, além de outros suportes não impressos, de forma a ir ao encontro das necessidades informacionais, educacionais, culturais e reabilitacionais da população reclusa. Devendo alertar para a atualização do acervo, qualidade, organização e manutenção do material, pois geralmente o acervo bibliográfico recebe tratamento equivalente ao do preso, tido como desnecessário, irrelevante e, na maioria das vezes, ignorado.

Em contrapartida, Bayley (1981 apud CHACÓN ALVARADO, 1993) considera que, embora as coleções das bibliotecas prisionais sejam de grande valia para o desenvolvimento do preso, os documentos devem ser constante e minuciosamente avaliados a fim de se detectar possíveis danificações ocasionadas com intuitos desordeiros, fraudulentos ou violentos.

Tabela 1 - Possíveis problemas ocasionados pelo mal uso de materiais bibliográficos.

\begin{tabular}{ll}
\hline \multicolumn{1}{c}{ Formato } & \multicolumn{1}{c}{ Posibles problemas } \\
\hline $\begin{array}{l}\text { Libros de pasta suave e historietas } \\
\text { cômicas }\end{array}$ & $\begin{array}{l}\text { Pueden ser usados para iniciar un incendio o } \\
\text { para obstruir los servicios sanitarios }\end{array}$ \\
Revistas y periódicos & Igual al anterior \\
Libros de pasta dura & Pueden ser usados para ocultar contrabandos \\
Juegos y rompecabezas & Los dados pueden ser usados para apuestas \\
Mapas, pinturas y posters & $\begin{array}{l}\text { Las regulaciones de las cárceles pueden } \\
\text { prohibir colgar cosas en las paredes, porque }\end{array}$ \\
\hline
\end{tabular}


se puede esconder contrabando detrás de las pinturas, etc.

Discos, cassetes, películas, cassetes de vídeo

Fonte: Bayley
Pueden violar la prohibición de seguridad en cuanto a metales. Los cables pueden ser usados para hacer armas.

Em todos os estados brasileiros, a situação das poucas bibliotecas prisionais existentes é alarmante. Falta de estrutura física, recursos humanos e de material bibliográfico são os principais problemas. Eiras (2007, p. 6), então, sugere que a gestão das bibliotecas prisionais seja efetuada por um órgão federal ou mesmo regional, no intuito principal de aperfeiçoar a qualidade dos serviços prestados por esses espaços. Para tanto, o autor acredita que a cada quinhentos reclusos deva existir um bibliotecário responsável e um auxiliar de biblioteca. $\mathrm{Na}$ conjuntura brasileira, em que a maior parte das prisões estão superlotadas, chegando a números acima de mil reclusos, se faz necessário, no mínimo, um bibliotecário responsável, um técnico profissional e dois auxiliares.

No Distrito Federal - universo de estudo da pesquisa - segundo informações da Fundação de Amparo ao Trabalhador Preso (FUNAP), existem 10 bibliotecas instaladas nas instituições do Sistema Penitenciário do DF:

$\Rightarrow$ Uma biblioteca no Centro de Internamento e Reeducaão (CIR);

$\Rightarrow$ Uma biblioteca no Centro de Detenção Provisória (CDP);

$\Rightarrow$ Duas bibliotecas na Penitenciária I do Distrito Federal (PDF I);

$\Rightarrow$ Duas bibliotecas na Penitenciária II do Distrito Federal (PDF II). Esta e as outras três instituições citadas anteriormente estão fixadas no Complexo Penitenciário da Papuda, na cidade satélite de São Sebastião- DF;

$\Rightarrow$ Uma biblioteca no Centro de Progressão Penitenciária (CPP), situada no Setor de Indústria e Abastecimento de Brasília;

$\Rightarrow$ Três bibliotecas na Penitenciária Feminina do Distrito Federal (PFDF), localizada na cidade satélite do Gama - DF.

Todas as bibliotecas dos estabelecimentos prisionais do Distrito Federal são compostas por livros adquiridos por meio de doações de empresas privadas, da comunidade, de editoras locais, doações de familiares de presos, de escolas e bibliotecas públicas, além de aquisições, embora raras vezes, realizadas pelo Governo do Distrito Federal (GDF). 


\title{
4.5 BIBLIOTECÁRIOS NAS PRISÕES
}

\begin{abstract}
Os bibliotecários nos países do Terceiro Mundo necessitam desenvolver um senso crítico em relação à política de informação, principalmente no que se refere à questão da transferência da informação. Não podem ficar omissos, nem alienados, absorvendo informações de modo passivo [...] (Sueli A. Amaral).
\end{abstract}

O bibliotecário é imperativo no contexto das bibliotecas prisionais como colaborador do serviço social prestado.

Na maioria dos países, assim como no Brasil, não existem normas reguladoras para o serviço bibliotecário nas prisões, todavia, como exemplo, no Canadá, Holanda, Tailândia, Estados Unidos e Espanha esta regulamentação já é realidade há algum tempo.

Chacón Alvarado (1993) menciona que ao se falar em bibliotecas de estabelecimentos prisionais, logo se pensa em um lugar frio e triste, com algumas estantes com livros e revistas. Contudo, o que se percebe é que as bibliotecas prisionais são importantes instituições de educação e reabilitação dos detentos. Destaca o bibliotecário como sendo o principal elemento destas bibliotecas e evidencia a grande significância de seu trabalho para os detentos:

\footnotetext{
Cuando se menciona la frase "Bibliotecas de las prisiones" se piensa en un lugar frío y triste. Probablemente en un lugar que tiene unos estantes con libros y revistas. Sin embargo, las bibliotecas de las prisiones son instituciones que juegan un papel importante en la educación y rehabilitación de los prisioneros. Los bibliotecólogos son el elemento más importante de éstas y su misión es convertir ese lugar en uno dinámico con servicios apropiados para sus usuarios, en este caso, los prisioneros. (CHACÓN ALVARADO, 1993, online)
}

Sanches (2008) confirma que o profissional bibliotecário tem competências e ensejos de trabalhar em um ambiente com grande intervenção social. As bibliotecas de institutos prisionais são terrenos favoráveis à intensificação e definição do papel social do bibliotecário, enquanto mediador e orientador do acesso à informação e ao conhecimento.

Eiras (2007) expôs que as competências dos bibliotecários prisionais são semelhantes às do profissional da informação que trabalha numa biblioteca pública, pois ambos estão relacionadas com o tratamento da informação, com a literacia, a educação e a cultura. Assim, o autor cita as qualidades e atribuições desejáveis e necessárias para um bibliotecário prisional:

\footnotetext{
- Equilíbrio emocional;

- Postura dinâmica;
} 
- Boa cultura geral;

- Capacidade de adaptação (ambiente prisional);

- Boa comunicação oral;

- Conhecimentos de línguas (depende do país e do contexto);

- Capacidade de liderança e de supervisão (trabalho com reclusos);

- Interesse em trabalhar com a diversidade cultural, étnica e lingüística;

- Gosto em trabalhar na educação de adultos;

- Criatividade;

- Sensibilidade e atenção;

- Capacidade inventiva e de abstração;

- Conhecimentos de Direito e de legislação penal (Id., p. 5).

O bibliotecário tem a incumbência de transmitir o conhecimento, tem como dever ser o mediador de leituras e buscar fazer do livro um companheiro inseparável, nas mais infinitas situações, para cada indivíduo e o ambiente prisional torna-se ideal para o exercício destas responsabilidades. Petit (1999 apud OLIVEIRA, D., 2004, p. 4) define o mediador como "un maestro, un bibliotecario, un documentalista, o a veces un librero, [...], un trabajador social o un animador social voluntario, un militante sindical o político, hasta un amigo o alguien con quien se topa uno"(p. 6).

Segundo Lehmann (1999), durante conferência geral realizada pela IFLA em 1999, os bibliotecários que trabalham em bibliotecas prisionais têm maiores possibilidades de êxito se possuírem uma educação adicional ou experiência profissional em outras áreas do conhecimento como psicologia, criminologia, pedagogia ou serviço social.

Portanto, o sucesso do bibliotecário em meio prisional depende basicamente que o profissional tenha consciência das particularidades do ambiente penitenciário e que possua, entre vários predicados, grandes doses de paciência, imparcialidade, tolerância, equilíbrio emocional e, até mesmo, humor. Estas qualidades, dentro das instituições penais, se mostram mais eficientes para o êxito do profissional que o desenvolvimento das funções próprias de sua profissão.

As semelhanças entre bibliotecas públicas e as bibliotecas especiais prisionais são maiores do que as diferenças. A melhor maneira de como se construir uma carreira de bibliotecário especializado em bibliotecas de estabelecimentos prisionais é feita com uma formação acadêmica que inclua serviços de extensão, alfabetização, recursos multiculturais e materiais de ensino para indivíduos com algum impedimento - físico, psíquico ou judiciário.

Apesar de nem todos os profissionais bibliotecários estarem preparados ou possuírem entusiasmo para atuarem em estabelecimentos prisionais, como afirma Eiras (2007, p. 5), àqueles que se dispuserem a cumprir trabalhosa função devem ter consciência de seu papel profissional, além de entender e apreender os desafios presentes em um "ambiente [...] repleto de ambiguidades e paradoxos. 
Em meio prisional, a pressão do 'mais forte sobre o mais fraco' pode ser uma realidade constante e por vezes insuportável. Ao estar disponível para responder às necessidades dos reclusos, o bibliotecário pode ganhar uma grande importância no seu dia-a-dia, enquanto elemento compensador dos desequilíbrios resultantes da vivência prisional.

No entanto, nem tudo são dificuldades e existem muitas vantagens e compensações para um bibliotecário prisional competente. Este profissional deve conseguir realizar-se através da disponibilização de serviços específicos e da criação e desenvolvimento de uma biblioteca que sirva as necessidades de um grupo fechado mas bastante heterogêneo ( Ibid.).

Chacón Alvarado (1993) considera que as bibliotecas prisionais, em termos gerais, têm sido ignoradas pelas instituições responsáveis pelo seu desenvolvimento. Para a Section for Libraries Serving Disadvantaged Persons (LSDP), quando presente no espaço carcerário onde se encontram e independentemente do crime que tenham cometido, a maior parte dos detentos veem a biblioteca do estabelecimento prisional com "bons olhos", a estimam e consideram-na importante, assim como os afazeres desempenhados pelo profissional bibliotecário, visto que em muitos casos somente durante o cumprimento de sua pena o recluso tem os primeiros contatos como utilizador de uma biblioteca. 


\section{ESTUDO DE CASO: BIBLIOTECA DO CENTRO DE INTERNAMENTO E REEDUCAÇÃO (CIR/“PAPUDA”)}

O presente estudo de caso tem por objetivo subsidiar e propiciar informações que venham ao encontro de toda investigação realizada, exemplificando o que foi exposto e situando o leitor mais próximo dos temas apresentados.

Vilabol (apud RODRIGO, 2008, p. 3) qualifica o estudo de caso:

É uma categoria de pesquisa cujo objeto é uma unidade que se analisa profundamente. Pode ser caracterizado como um estudo de uma entidade bem definida, como um programa, uma instituição, um sistema educativo, uma pessoa ou uma unidade social. Visa conhecer o seu "como" e os seus "porquês", evidenciando a sua unidade e identidade própria. É uma investigação que se assume como particularística, debruçando-se sobre uma situação específica, procurando descobrir o que há nela de mais essencial e característico.

\subsection{NÚCLEO DE CUSTÓDIA DE BRASÍLIA (NCB)}

O Núcleo de Custódia de Brasília (NCB), hoje chamado de Centro de Internação e Reeducação (CIR), é um presídio exclusivamente masculino situado no Complexo Penitenciário da Papuda, na cidade satélite de São Sebastião, Distrito Federal.

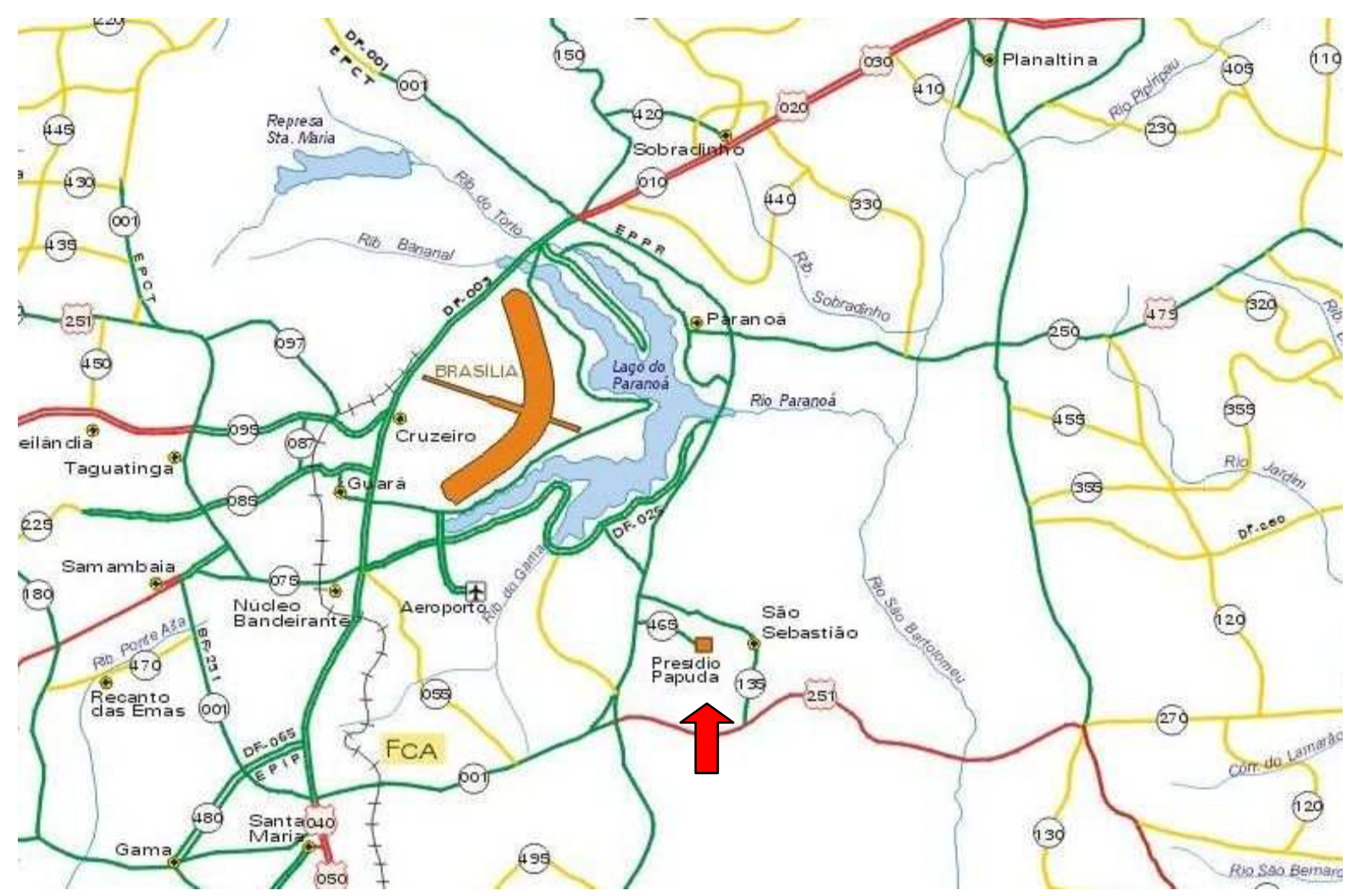

Figura 1 - Mapa do Distrito Federal 
De acordo com informações históricas, a Penitenciária da Papuda, como é conhecida, recebeu esse nome porque está localizada em uma região entre o Rio Gama e os Ribeirões Taboca e Santo Antônio da Papuda, chamada de Fazenda da Papuda. A região era uma propriedade particular que foi desapropriada pelo então governo do estado de Goiás quando da definição do território do Distrito Federal, hoje pertencente à Companhia Imobiliária de Brasília (Terracap), empresa pública da administração indireta do Distrito Federal, transformada em agência de desenvolvimento em 1997.

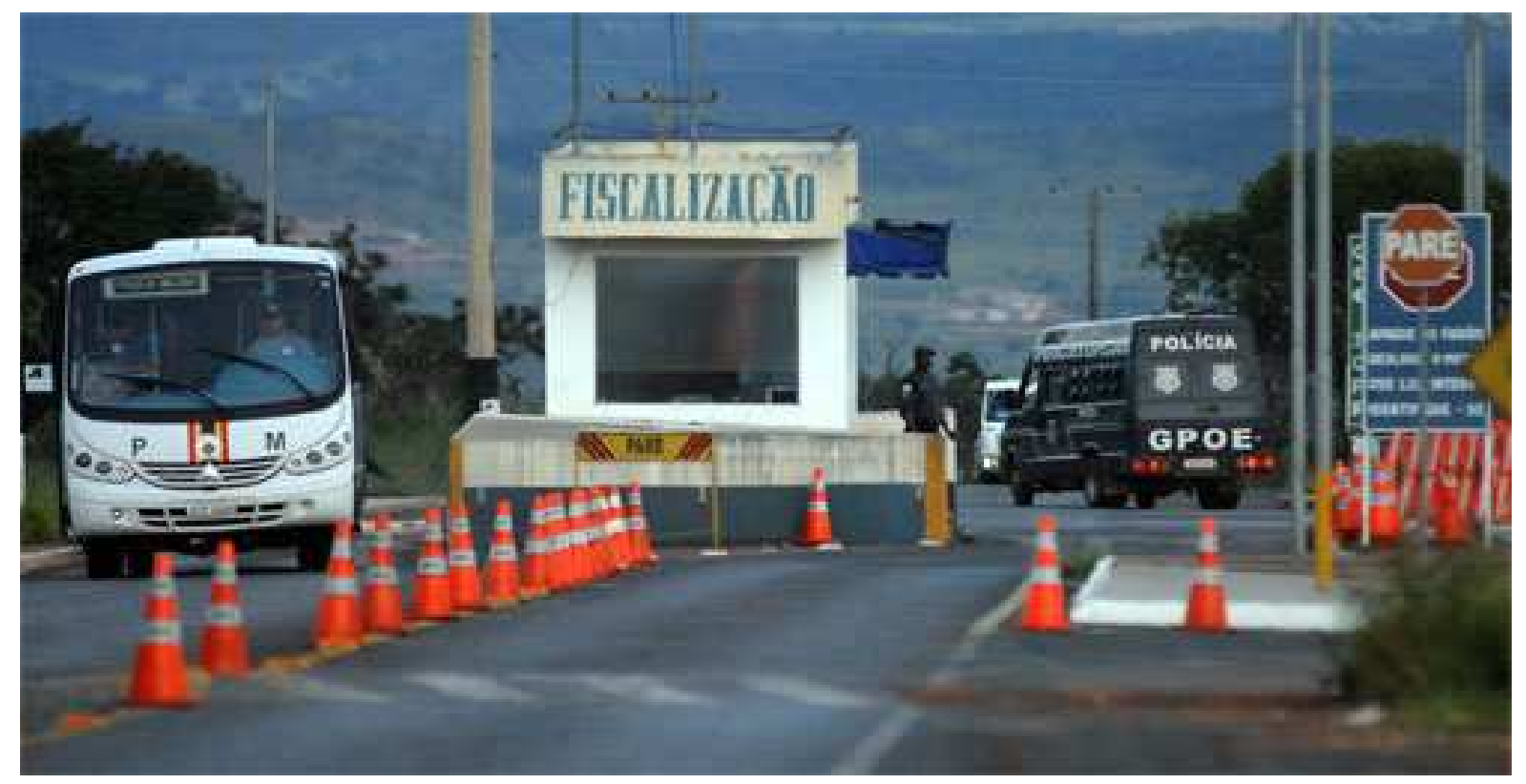

Figura 2 - Guarita de entrada do Complexo Penitenciário da Papuda

O CIR foi inaugurado em 16 de janeiro de 1979 para receber inicialmente 240 presos, hoje tem capacidade para abrigar cerca de 800 internos, entretanto, segundo dados da Secretaria de Estado de Justiça, Direitos Humanos e Cidadania (SEJUS), apresenta atualmente uma população de mais de 1500 detentos. Faz parte de um complexo penitenciário formado por quatro conjuntos prediais que abrigam juntos cerca de oito mil presidiários; foi criado, inicialmente, para detentos condenados a até dez anos de reclusão em regime fechado sem direito a saídas. Atualmente destina-se ao recolhimento de sentenciados que cumprem pena privativa de liberdade no regime semi-aberto. Situado na Rodovia DF 465, km 4, a uma distância de $15 \mathrm{~km}$ a sudeste do Plano Piloto do Distrito Federal e localizada em um vale, cerca de $950 \mathrm{~m}$ acima do nível do mar, onde à sua volta, as regiões mais altas chegam a atingir uma altitude de $1.150 \mathrm{~m}$. 


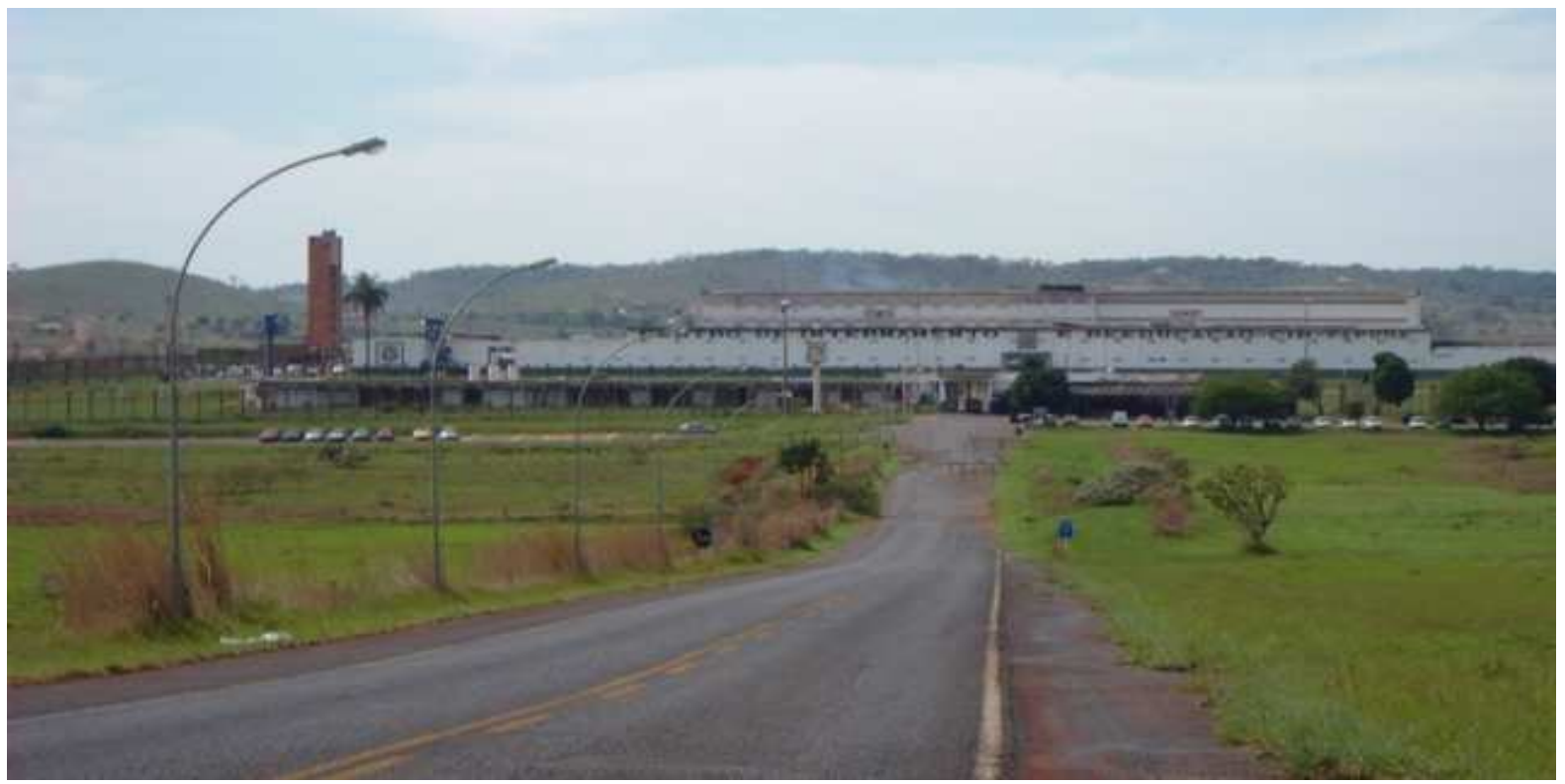

Figura 3 - Centro de Internamento e Reeducação I

Inicialmente, o Centro de Internamento e Reeducação, assim como todo o complexo penitenciário, foi projetado para ficar isolado do meio urbano, contudo, com o crescimento populacional desordenado vigorante no Distrito Federal desde sua inauguração em 21 de abril de 1960, em especial após a década de 1990, fez com que atualmente o Complexo Penitenciário da Papuda se encontre a poucos metros do limite topográfico da cidade satélite de São Sebastião, sendo uma preocupação para a população local e, também, para a segurança do próprio Complexo Penitenciário.

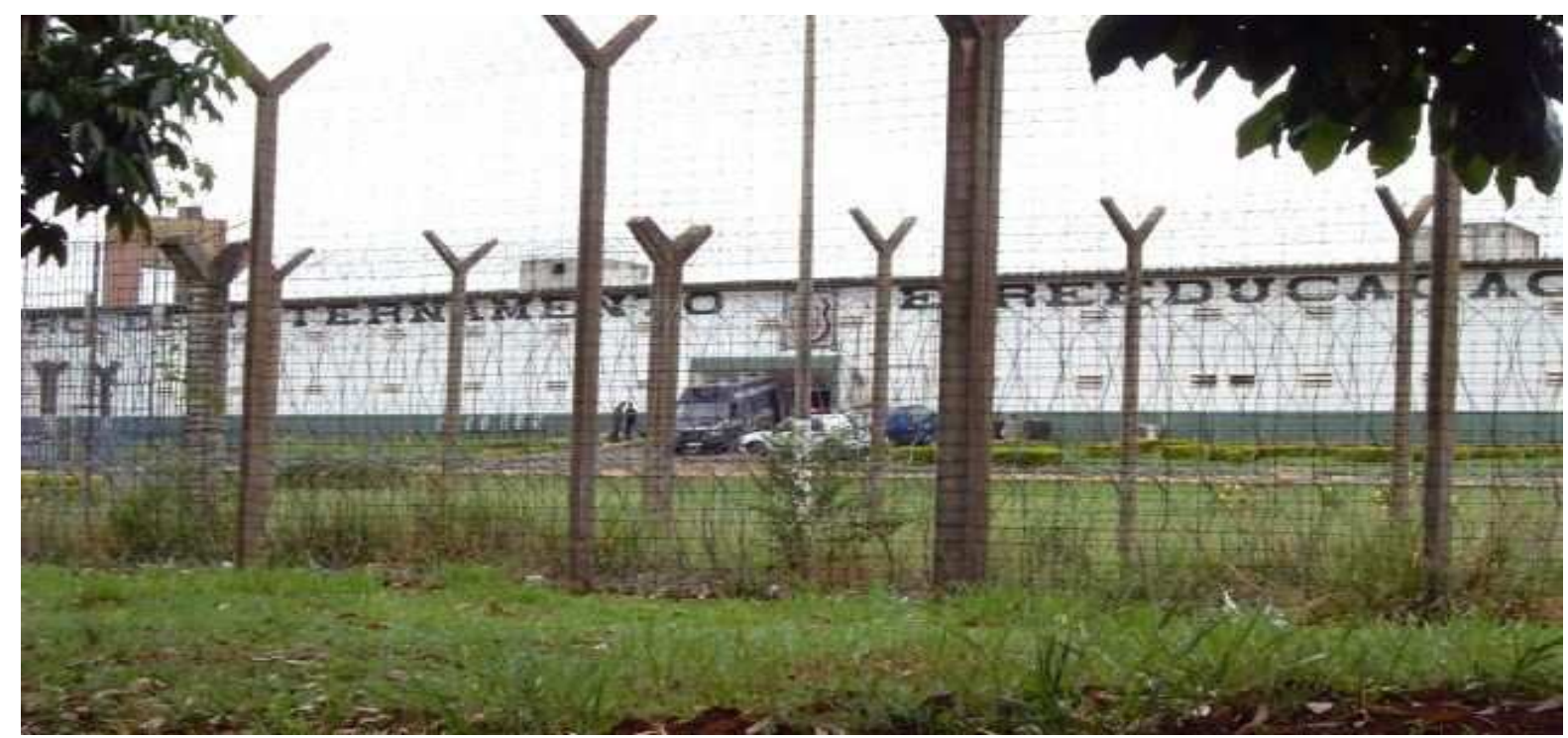

Figura 4 - Centro de Internamento e Reeducação II 


\subsection{BIBLIOTECA NOVA VIDA}

A Biblioteca do Centro de Internamento e Reeducação foi regulamentada e implantada pelo Decreto do Governo do Distrito Federal No 26.637, de 16 de março de 2006, promulgado no Diário Oficial do Distrito Federal de 17 de março do mesmo ano.

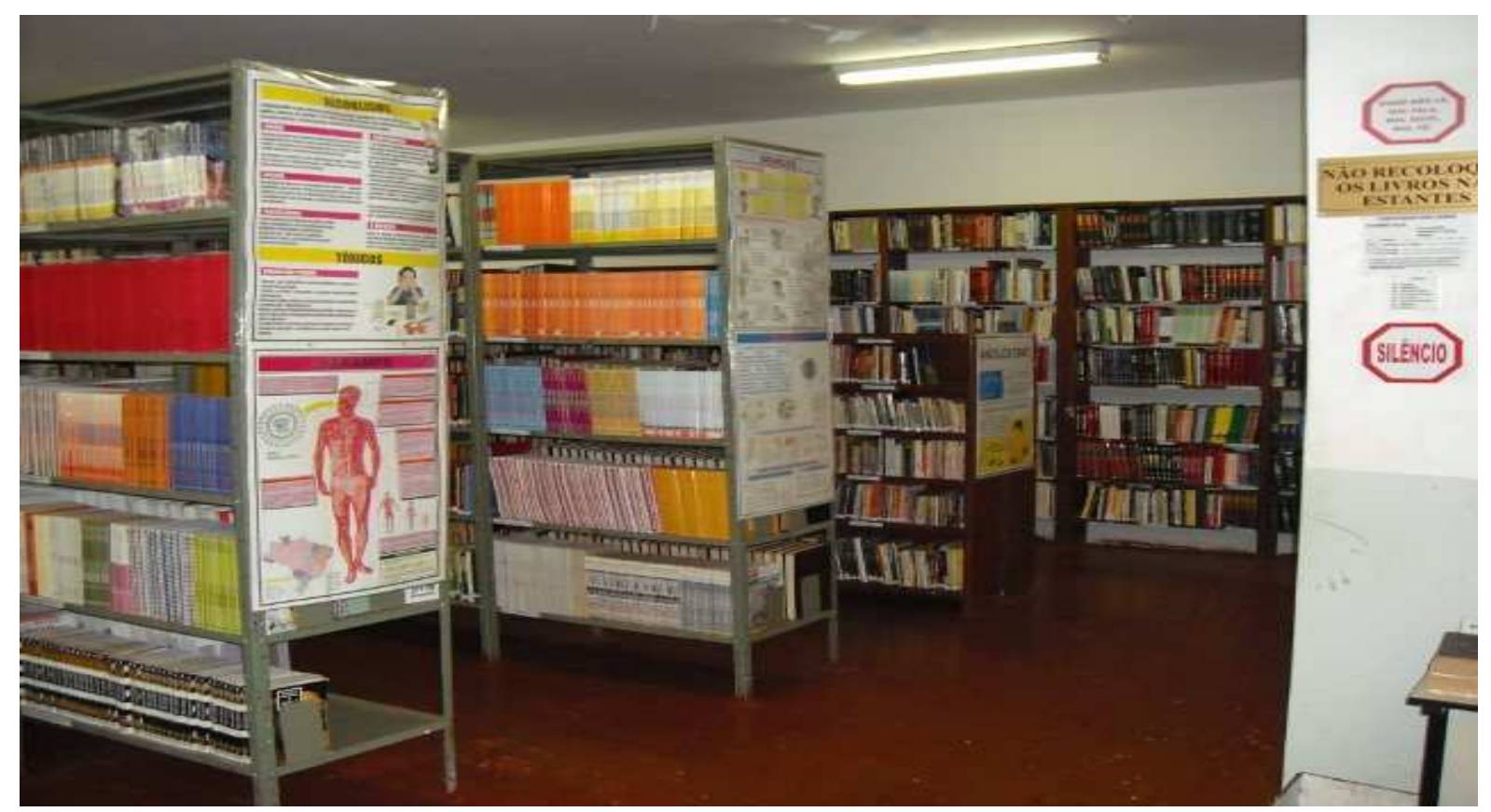

Figura 5 - Biblioteca Nova Vida.

A história da Biblioteca teve seu início quando em 1995 a Fundação de Amparo ao Trabalhador Preso do Distrito Federal, pessoa jurídica de direito privado, sem fins lucrativos, dotada de autonomia técnica, administrativa, financeira e operacional, vinculada à Secretaria de Estado de Justiça, Direitos Humanos e Cidadania do Distrito Federal, instituída por escritura pública em 03 de fevereiro de 1987, decidiu realizar mais um de seus projetos de reinserção social e melhoramento das condições de vida e psicossocial dos detentos: a organização de uma biblioteca no Centro de Internamento e Reeducação do Complexo Penitenciário da Papuda.

Para a concretização do projeto de estruturação da biblioteca, a FUNAP-DF firmou convênio com a Biblioteca Demonstrativa de Brasília (BDB), estabelecendo as responsabilidades de cada uma na transformação de uma sala já existente no pavilhão de ensino do CIR, composta por um pequeno amontoado de livros velhos e desatualizados, em uma pequena e verdadeira biblioteca. 


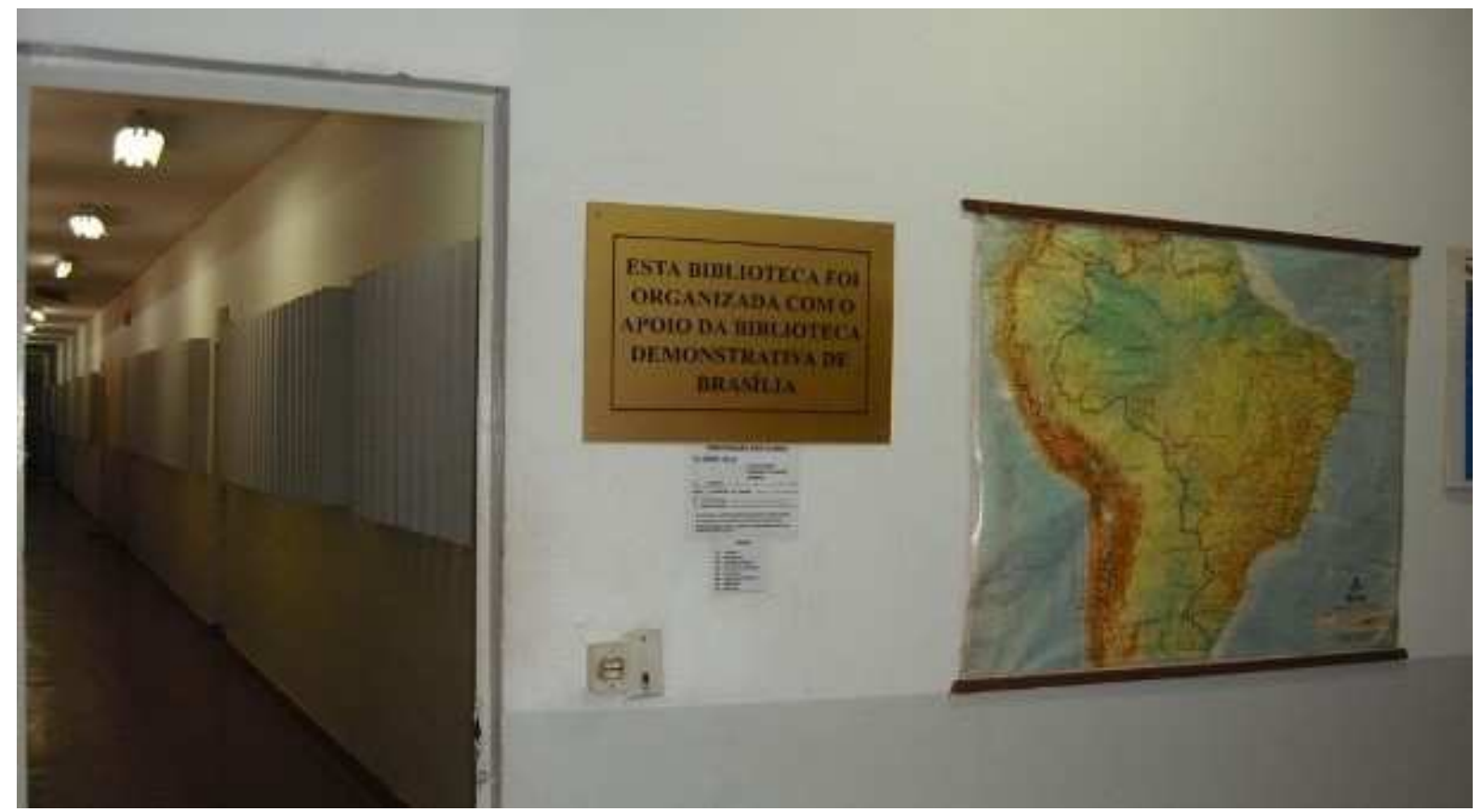

Figura 6 - Porta de entrada da Biblioteca Nova Vida (Visão interna).

À FUNAP-DF coube a responsabilidade pela liberação de recursos financeiros e aquisição de todo material necessário para organização da biblioteca: mobiliário; máquinas de datilografia, uma vez que o computador ainda não era tão popular quanto atualmente; material para restauração de livros; material gráfico, como fichas catalográficas, cartões, etiquetas, etc. Incumbiu-se, também, à Fundação o encargo de dar liberdade de ação e segurança à coordenadora da BDB, Maria da Conceição Moreira Salles, durante toda a implementação do projeto, além de divulgar o projeto e arrecadar novos livros para o acervo da nova Biblioteca.

A Biblioteca Demonstrativa de Brasília foi selecionada para implementação do projeto da Biblioteca do CIR por promover a inclusão social e fortalecer a cidadania, por de ser considerada modelo de instituição de serviços e atividades educativas e culturais desde sua inauguração oficial em novembro de 1970, e ao apoiar o projeto teve como imputabilidade a logística de elaboração do projeto e treinamento dos colaboradores, dentre eles alguns detentos escolhidos obedecendo aos critérios de bom comportamento e escolaridade. Assim como à FUNAP-DF, a BDB, também, ficou responsável pelo marketing do trabalho e pela angariação de documentos novos e atualizados para a composição e renovação do acervo da Biblioteca. 


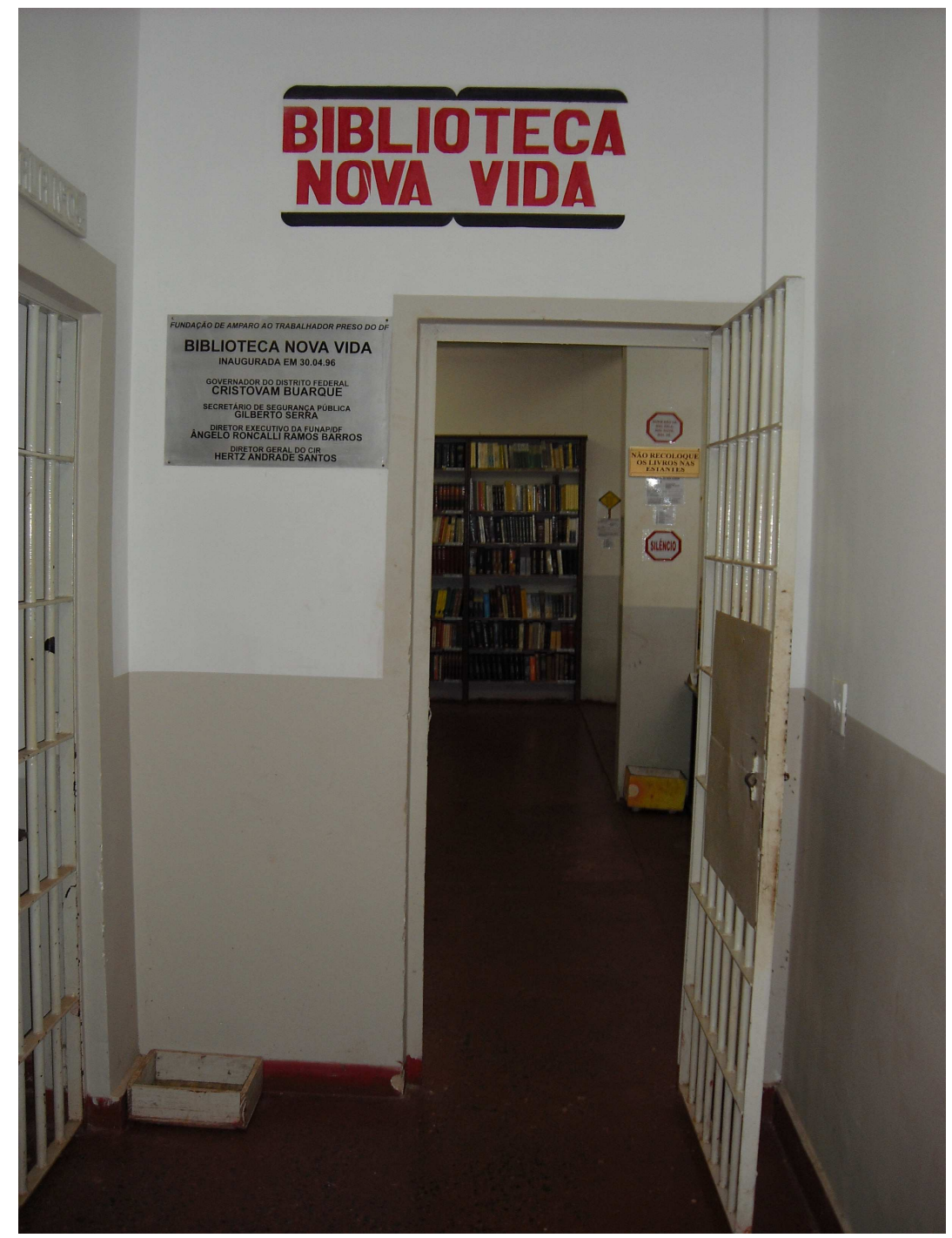

Figura 7 - Porta de entrada da Biblioteca Nova Vida (Visão externa).

Ao elaborar o projeto de organização da 'Biblioteca da Papuda' a BDB e a FUNAPDF estabeleceram-se como objetivos específicos:

$\checkmark$ Facilitar o acesso à informação e promover a difusão da cultura entre internos do Centro de Internamento e Reeducação;

$\checkmark$ Incentivar e motivar a freqüência à biblioteca;

$\checkmark$ Estimular o hábito da leitura, demonstrando suas vantagens por meio de atividades culturais regulares como concursos literários, recitais de poesias, palestras, projeção de filmes e debates;

$\checkmark$ Apoiar as atividades pedagógicas desenvolvidas pela Fundação de Amparo ao Trabalhador Preso do Distrito Federal - FUNAP-DF - no Complexo Penitenciário da Papuda; 
$\checkmark$ Cooperar com o programa de reabilitação de internos desenvolvido no CIR, ressaltando que somente participariam do projeto os internos considerados de bom comportamento.

$\checkmark$ Adquirir, selecionar, conservar e preservar livros, periódicos e documentos.

Dois anos depois do início da implementação do projeto conjunto da FUNAP/BDB, ou seja, em 1997, os objetivos estabelecidos inicialmente foram ratificados pelo artigo $2^{\circ}$ da Lei que criava a Biblioteca do Complexo Penitenciário da Papuda (Lei $\mathrm{n}^{\circ} 1.663$, de setembro de 1997).

O projeto teve como etapas:

I. Definição do projeto e coleta de dados para sua efetivação;

II. Definição dos objetivos;

III. Avaliação da situação pedagógico-estrutural do ambiente destinado à Biblioteca;

IV. Aquisição, seleção e descarte do acervo;

V. Treinamento dos colaboradores;

VI. Avaliação do sucesso do projeto.

Foram treinados cerca de quinze colaboradores, segundo informações da coordenadoria vigente na época, incluindo dez detentos, que realizaram atividades de seleção, registro, catalogação, classificação e indexação do acervo, etiquetação, organização dos documentos nas estantes, etc.

O acervo foi adquirido por meio de doações, no qual foram angariados milhares de livros, periódicos, folhetos e documentos diversos, em variados assuntos, naturezas e suportes. Posteriormente à seleção do acervo, descartaram-se todos os documentos com conteúdo predominante e/ou incitante à violência e/ou à sexualidade, por questão de segurança e adequada conduta no ambiente prisional.

Com a concretização do projeto, o novo setor de ensino e cultura do CIR precisava ganhar um nome. Foi feito um concurso com a participação livre de todos os detentos para a escolha do nome da biblioteca. Por se tratar a biblioteca de um objeto social capaz de provocar mudanças comportamentais e intelectuais, abrindo horizontes e causando desenvolvimento pessoal, a denominação escolhida foi "Biblioteca Nova Vida". 


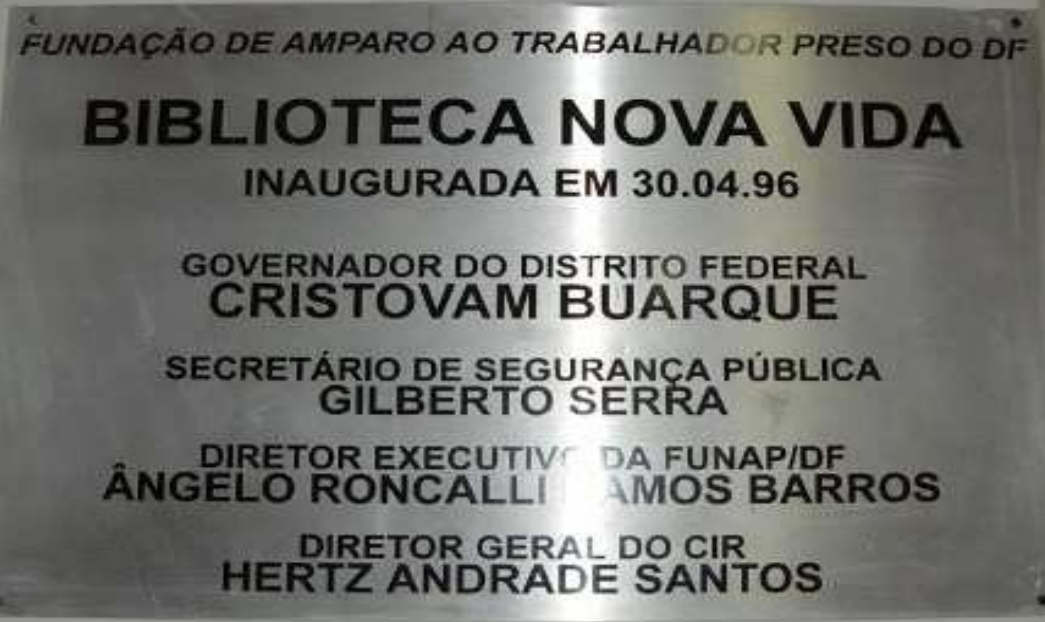

Figura 8 - Placa inaugurativa da Biblioteca Nova Vida.

A Biblioteca Nova Vida trouxe novas aspirações e deu ânimo àqueles que não podiam enxergar o mundo externo à Penitenciária ou que perderam o entusiasmo pela leitura e conhecimento. Seguem alguns depoimentos de detentos encarcerados ainda na época da implementação do 'Projeto Biblioteca da Papuda', retirados do estudo de Lima, S., (2002, p. 34):

Foi entre aquelas quatro paredes úmidas, de cheiro desagradável e de luz escassa que tive o meu primeiro contato com o nosso ilustre amigo, 'o livro' [...] E foi assim, entre quatro paredes que agora, não são mais úmidas, exalam cheiro agradável e tem luz abundante, que aprendi a valorizar a liberdade, a vida e a ânsia de um mundo mais justo e pacífico. (J.C.P.)

A biblioteca é de fundamental importância para todos e principalmente para mim. Sou freqüentador assíduo há um ano e meio. Para mim é o lugar que consigo aprender mais [...] Fico admirado em se ter uma biblioteca mesmo dentro de uma penitenciária [...] Uns estudam livros didáticos, outros procuram uma revista ou qualquer tipo de leitura que possa distrair e, de alguma forma, atravessar os muros e sonhar com o mundo exterior. (J.D.)

Somos muito carentes de livros que nos levem a despertar nossa curiosidade pela leitura, pois quando descobrimos que é bom fazer uma leitura, automaticamente estamos despertando para um novo conhecimento [...]. (P.I.B.)

Em 2006, o Governador do Distrito Federal ao decretar a regulamentação da implantação e do funcionamento da Biblioteca Nova Vida no Complexo Penitenciário da Papuda (Decreto N$^{\circ}$ 26.637, de 16 de março de 2006), estabelece em seu artigo $1^{\circ}$, Parágrafo único, que a FUNAP-DF “poderá criar novas unidades da Biblioteca Nova Vida nos outros 
estabelecimentos penais do Distrito Federal", demonstrando a importância e a valorização do projeto iniciado mais de uma década antes.

\subsubsection{Dados atuais da Biblioteca Nova Vida - CIR}

Todos os dados da Biblioteca Nova Vida foram coletados com a contribuição particular da bibliotecária responsável pela coordenação de todas as bibliotecas do Sistema Penitenciário do DF administradas pela FUNAP-DF, Sharlene Araújo.

\subsubsection{Missão}

Não foram encontradas informações documentadas sobre a missão da Biblioteca Nova Vida.

\subsubsection{Objetivos}

Facilitar o acesso à informação, apoiar as atividades pedagógicas desenvolvidas junto aos estabelecimentos penais do Distrito Federal pela Fundação de Amparo ao Trabalhador Preso; promover a difusão da cultura; estimular o hábito de leitura e cooperar com o processo de recuperação dos internos.

Mantêm-se os objetivos propostos quando da elaboração do projeto inicial de implementação da biblioteca no NCB.

\subsubsection{Normas de Funcionamento}

Não existem documentos específicos, com normas de funcionamento da Biblioteca e regras para sua utilização.

Somente os matriculados no Núcleo de Ensino podem frequentar a Biblioteca, em horários previamente agendados e com o acompanhamento do professor responsável pela turma.

Apenas os internos localizados na Ala Especial, constituída por ex-policiais e bombeiros e detentos com nível superior, podem fazer empréstimo do material do acervo da Biblioteca.

\subsubsection{Horário de Funcionamento}

A Biblioteca permanece aberta de segunda a sexta-feira, exceto às quintas-feiras até uma hora antes do fim do expediente do Sistema Penitenciário do DF, ou seja, das nove às quinze horas. 


\subsubsection{Recursos humanos}

A equipe da BNV é composta por uma única bibliotecária, presente em dias programados em virtude de ser ela a coordenadora de todas as demais bibliotecas administradas pela FUNAP-DF; por dois monitores (detentos selecionados por bom comportamento) que realizam atendimento aos usuários, empréstimos, processamento técnico e organização do acervo; e, por agentes penitenciários que fazem a segurança do local durante as visitas dos internos.

\subsubsection{Setores/Departamentos}

Na Biblioteca Nova Vida não há seções estruturalmente separadas do ambiente do Acervo. Existem somente delimitações de espaços caracterizadas como Balcão de Atendimento, Acervo Geral e Espaço para estudo em grupo (Mesas e cadeiras dispostas sobre o espaço da Biblioteca podendo acomodar concomitantemente até 30 usuários sentados).

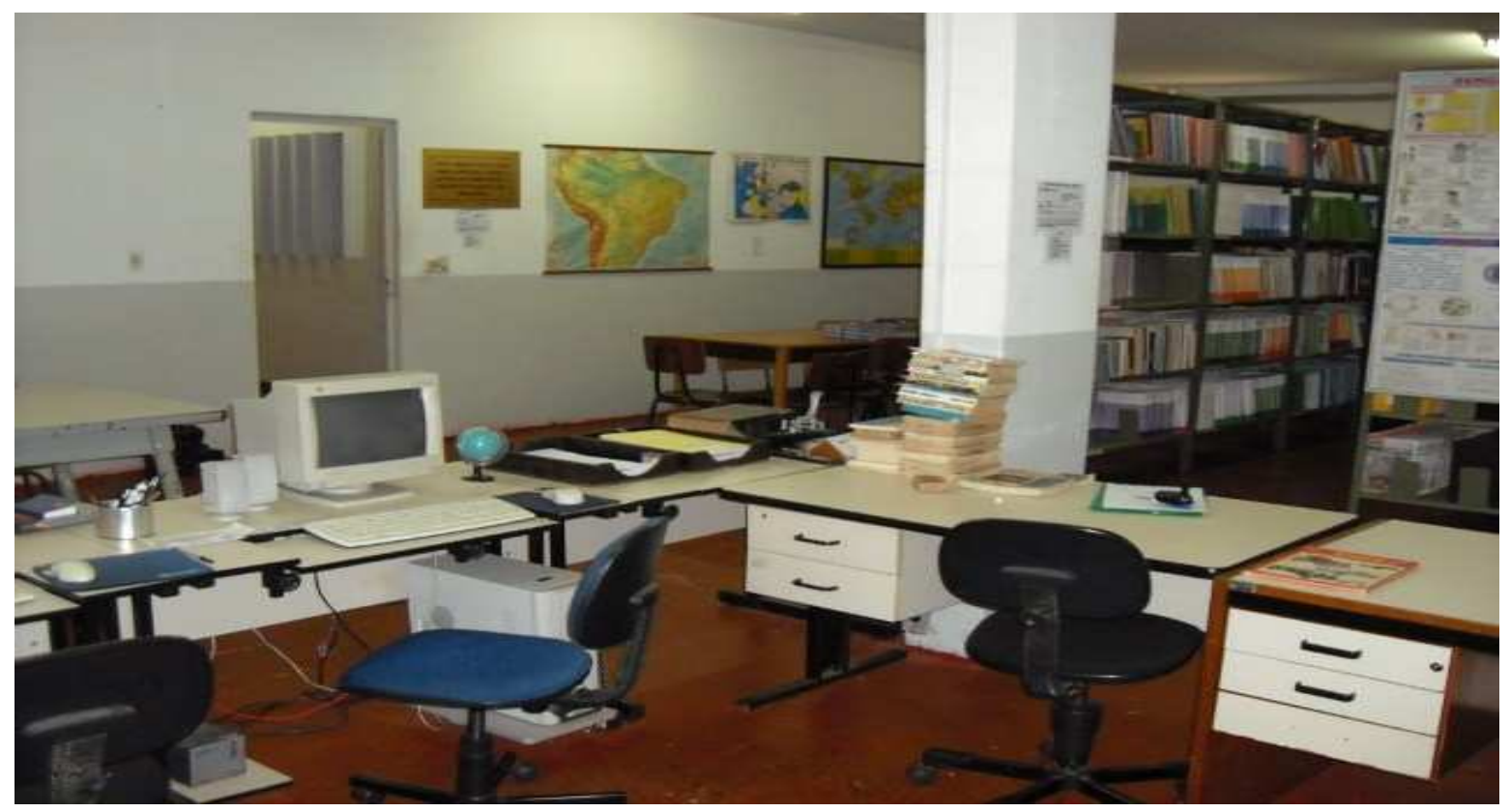

Figura 9 - Balcão de atendimento.

\subsubsection{Usuários}

O quadro de usuários da Biblioteca é composto por internos qualificados com bom comportamento e matriculados no Núcleo de Ensino do CIR; internos localizados na Ala Especial; professores do Núcleo de Ensino; policiais, técnicos penitenciários e demais funcionários que trabalham no CIR. 


\subsubsection{Acervo}

A biblioteca possui atualmente em seu acervo 10.160 volumes, divididos em:

\subsection{Acervo Geral}

10.000 volumes nas mais diversas áreas, como livros jurídicos, religiosos, didáticos, literatura, etc.

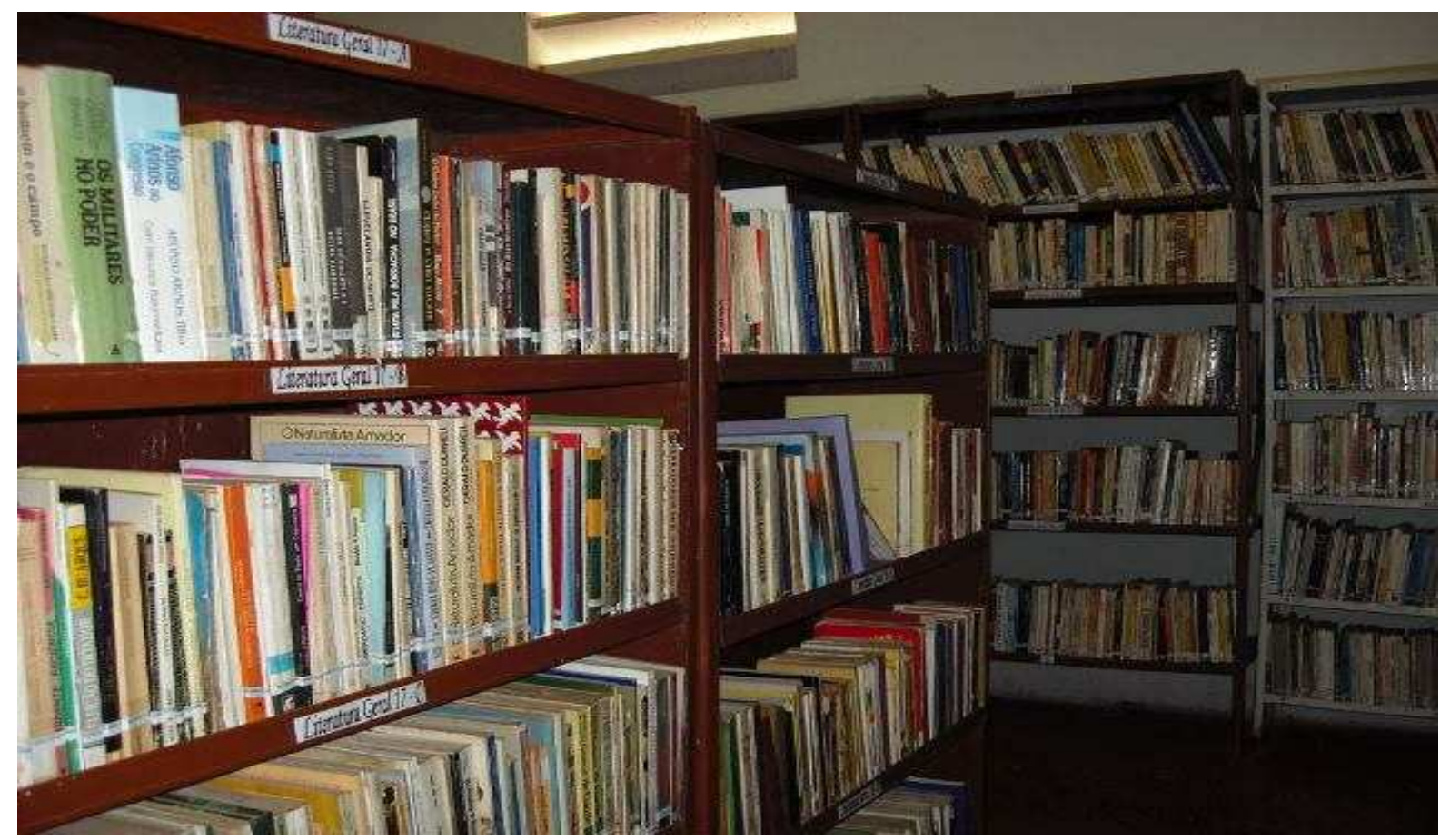

Figura 10 - Acervo Geral.

\subsection{Coleção de Periódicos}

A coleção de periódicos é composta por 80 revistas de várias temáticas. Além de ínfima, a coleção está completamente desorganizada. 


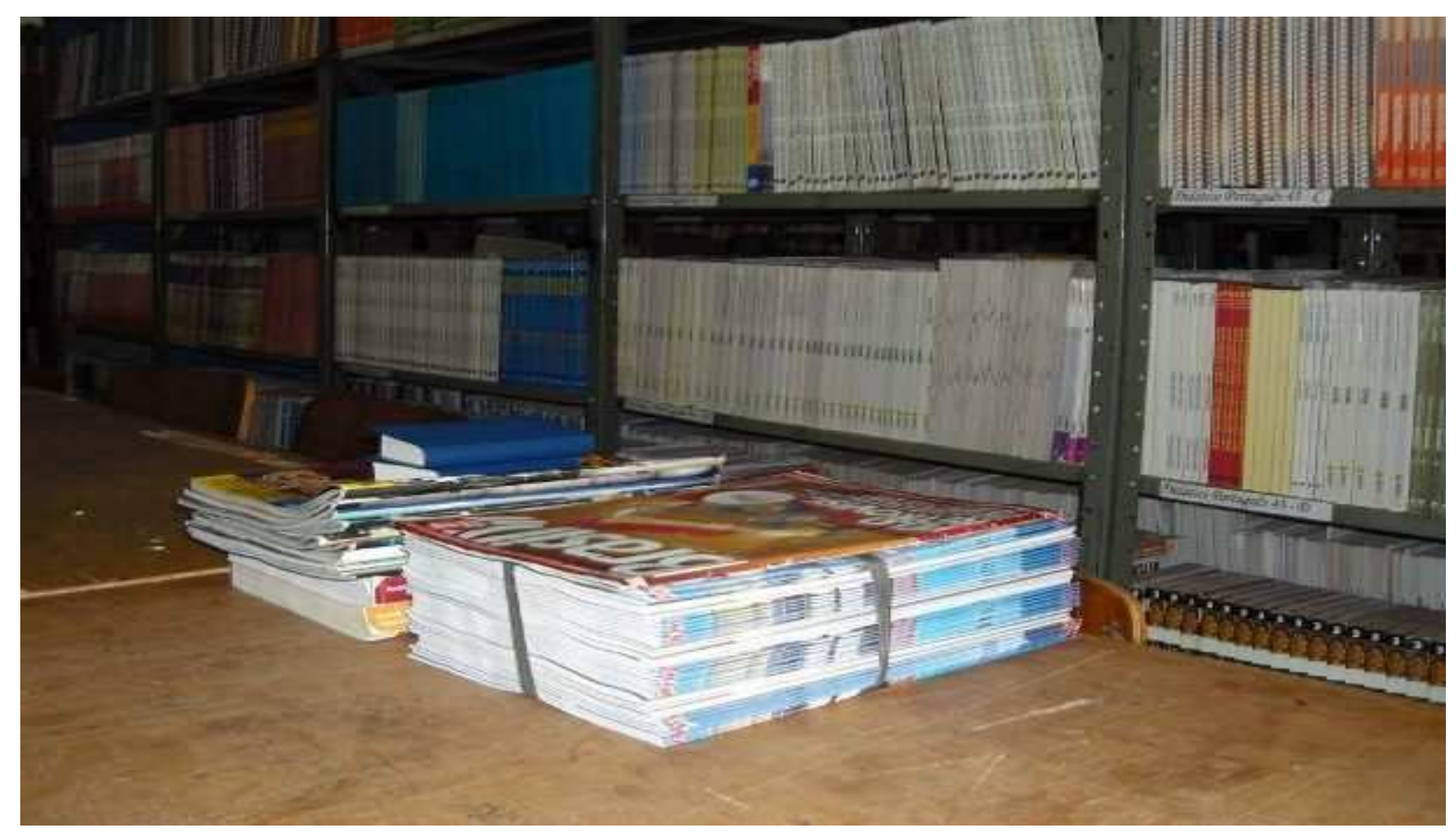

Figura 11 - Periódicos.

\subsection{Coleção de Multimeios}

A coleção de multimeios é formada por 80 volumes, incluindo fitas VHS e DVDs de vídeos instrutivos. Do mesmo modo que os periódicos, a coleção de multimeios está inteiramente desorganizada.

\subsubsection{Sistema de Classificação e Indexação}

O sistema de classificação utilizado foi baseado na Classificação Decimal Universal (CDU) e elaborado há alguns anos exclusivamente para a Biblioteca (figura 12). É um sistema que para o uso em acervo de bibliotecas distintas das bibliotecas prisionais não possui muita maleabilidade.

Não existe um vocabulário controlado, nem thesaurus. A indexação é feita através de vocabulário livre ou por extração de palavras-chaves retiradas do próprio documento. Procedimento esse que torna a recuperação de documentos e pesquisa de assuntos mais trabalhosa e com menos chances de sucesso. 


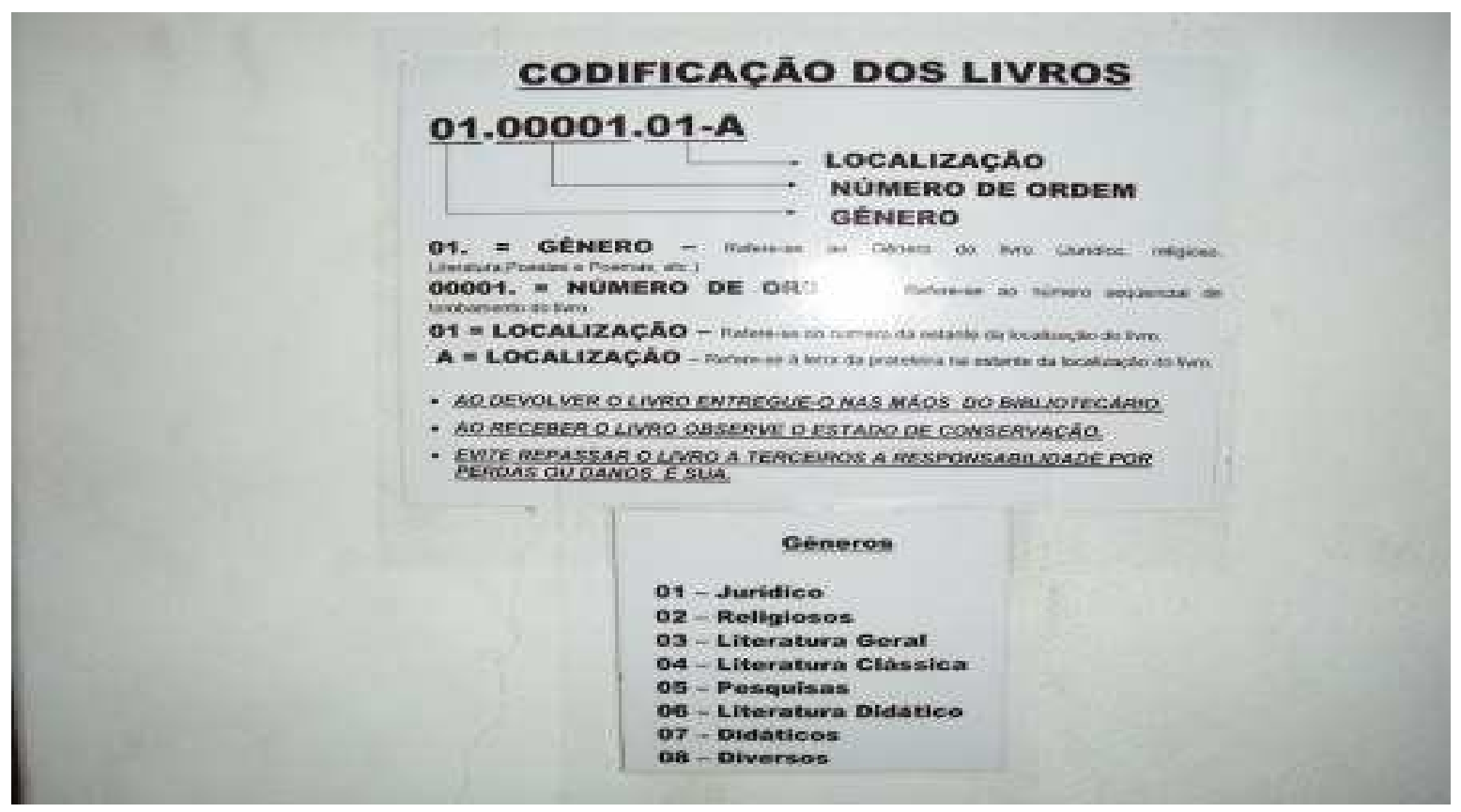

Figura 12 - Sistema de classificação e gêneros dos documentos da BNV.

\subsubsection{Produtos e Estatísticas da Biblioteca}

Devido a suas dificuldades e impedimentos, a Biblioteca Nova Vida não possui estudos estatísticos sobre seus serviços, tampouco possui nenhum produto desenvolvido por ela.

\subsubsection{Forma de Aquisição de Material Bibliográfico}

Todos os documentos disponíveis para uso na Biblioteca foram adquiridos por meio de doações.

Todo membro da comunidade pode doar materiais para a Biblioteca Nova Vida e demais bibliotecas prisionais do Distrito Federal.

Atualmente não existem critérios documentados em relação aos tipos e características de materiais doados que serão incorporados ao acervo, bem como, também não existe, uma relação formal de entidades que receberão os materiais doados que não farão parte do acervo da Biblioteca.

\subsubsection{Projetos em Execução}

Classificação de todo o material bibliográfico de acordo com o sistema de classificação baseada na CDU, criado especificamente para as bibliotecas do Sistema Penitenciário do DF, e estruturação da Biblioteca. 


\subsubsection{Pesquisa no Acervo}

A pesquisa é realizada em um único computador presente na Biblioteca Nova Vida.

As formas de pesquisa que o sistema de busca (não informado o nome) oferece são bastante simplificados e não permitem pesquisas mais elaboradas ou com trucagem, não podendo pesquisar, por exemplo, autor, título e assunto ao mesmo tempo;

Somente os funcionários têm acesso ao sistema, isso impede que o usuário possa fazer a sua própria pesquisa, o que, consequentemente, torna o serviço lento e cansativo.

\subsubsection{Atividades na Biblioteca}

Não existe um cronograma de atividades e nem definição de indicadores de qualidade dos serviços prestados pela Biblioteca. As atividades são definidas e decididas de acordo com os interesses dos professores do Núcleo de Ensino do Centro de Internamento e Reeducação.

\subsubsection{Críticas e Observações}

$\rightarrow$ A Biblioteca tem a necessidade de ter um bibliotecário em full time, uma vez que os monitores são detentos e a sua rotatividade é muito alta o que, por conseguinte, interfere e prejudica a continuidade dos trabalhos desenvolvidos na BNV;

$\rightarrow$ Os professores praticamente quase não marcam estudo em grupo na Biblioteca;

$\rightarrow$ A Secretaria do Núcleo de Ensino funciona na Biblioteca e os internos que auxiliam nos serviços da Biblioteca são também os "responsáveis" pela respectiva Secretaria;

$\rightarrow$ Há necessidade de mudança do software da Biblioteca, tendo em vista que o atualmente utilizado possui poucos aplicativos;

$\rightarrow$ Faltam materiais básicos para a concepção dos trabalhos (ex: papel A4, fita adesiva, etc.);

$\rightarrow$ Problemas com infiltração;

$\rightarrow$ Ventilação ruim;

$\rightarrow$ Falta material de limpeza;

$\rightarrow$ A mobília é antiga e já mostra sinais de deterioração;

$\rightarrow$ Faltam agentes penitenciários, o que acaba dificultando o trabalho do Núcleo de Ensino. 


\subsubsection{Desafios}

$\rightarrow$ Criar e organizar toda a documentação relativa à Biblioteca, para que sejam disponibilizadas para todos os interessados;

$\rightarrow$ Treinamento contínuo de monitores para que possam trabalhar como auxiliares de biblioteca;

$\rightarrow$ Instalação de um novo software nos computadores e migração dos dados (registros de usuários; registros do acervo);

$\rightarrow$ Atualização do acervo;

$\rightarrow$ Aquisição de novos computadores e novos mobiliários;

$\rightarrow$ Aquisição de banco e bases de dados para auxiliar o ensino e aprendizagem;

$\rightarrow$ Adoção de um vocabulário controlado e das normas internacionais de catalogação e de referências bibliográficas;

$\rightarrow$ Integração com outros órgãos públicos para possibilitar tanto a aquisição quanto o empréstimo entre bibliotecas;

$\rightarrow$ Criação do espaço do professor na Biblioteca;

$\rightarrow$ Elaboração de estudos de usuários.

No que tange ao uso da biblioterapia, embora haja muitas peculiaridades e dificuldades que possam afetar sua aplicação, não obstante sua utilização não ser considerada um projeto de execução e ainda se fazer timidamente, é incentiva pelos professores do Núcleo de ensino, como forma de aperfeiçoamento, melhoramento comportamental e ocupação do tempo ocioso dos detentos do CIR. A leitura, então, passa a compor um leque de poucas opções na capacidade de transformação do indivíduo que precisa entender seu erro e sua punição, e como afirma Baudelaire (apud GIDDENS, 2002, p.173), necessita enfrentar a tarefa de (re)produzir a si mesmo.

$\mathrm{O}$ ato de ler torna-se um processo abrangente de compreensão e intelecção do mundo que envolve o homem. Ao ler o leitor é "capaz de interpretar, imaginar, sonhar, (re)criar e ainda achar resolução para seus questionamentos” (MENDES, J., 2008, p. 19). 


\section{METODOLOGIA}

\subsection{TEORIA CIENTÍFICA}

Hoje se reconhece que a ciência e a tecnologia se viabilizam por meio de um processo de construção do conhecimento e que esse processo flui na esfera da comunicação (Edna L. Silva e Estera M. Menezes).

Considera-se a pesquisa científica como investigação organizada, planejada e desenvolvida com a finalidade de contribuir para o aperfeiçoamento cultural, intelectual e social da humanidade.

Santos (1999 apud FONTE, [S.d.], online) diferencia a investigação científica realizada por especialistas da investigação desempenhada por estudantes universitários. A distinção estaria nos desígnios e não na técnica utilizada, pois apesar de ambos trabalharem de acordo com as regras acadêmicas, o cientista busca impulsionar o progresso científico ao passo que o estudante, embora almeje o mesmo desenvolvimento, ainda está por aprimorar seu próprio conhecimento.

Minayo (1993 apud SILVA, E.; MENEZES, 2001, p. 19), considera a pesquisa científica "como atividade básica das ciências na sua indagação e descoberta da realidade. [...] É uma atividade de aproximação sucessiva da realidade que nunca se esgota, fazendo uma combinação particular entre teoria e dados".

De modo geral, os autores creem que o pesquisador ao propor um estudo sobre determinado assunto, busca destacá-lo do fosso de desconhecimento, encontrando respostas e possíveis soluções para determinado fim ou problema.

O método de pesquisa sempre dependerá da intenção do pesquisador. De acordo com os objetivos Silva, E.,; Menezes (2001), baseando-se em Gil (1991), classificam as pesquisas em exploratória, descritiva e explicativa (Tabela 1).

Tabela 2 - Tipos de pesquisa

Tipos de Pesquisa considerando os Objetivos

\begin{tabular}{llll}
\hline Kerlinger (1980) & Cervo \& Bervian (1983) & Richardson ET al. (1989) & Gil (1991) \\
\hline Básica & Pura & Formular Teorias & Exploratórias \\
& & Testar Teorias & Descritivas \\
Aplicada & Aplicada & Resolver Problemas & Explicativas \\
\hline
\end{tabular}

Fonte: UFPR 
No âmbito da Biblioteconomia, Cunha (1982) estabelece a metodologia de pesquisa relacionada aos usuários de informação de determinado estabelecimento. $\mathrm{O}$ autor ainda expõe que o estudo de usuários pode ser centrado na instituição ou no próprio usuário. De acordo com os propósitos, a pesquisa poderá ser fundamentada em técnicas de perguntas, observação ou análise documentária (Tabela 2).

Tabela 3 - Métodos para estudo de usuários.

\begin{tabular}{lll}
\hline PERGUNTAS & OBSERVAÇÃO & ANÁLISE DOCUMENTÁRIA \\
\hline Questionário & Observação participante & Diários \\
& Análise de conteúdo \\
Entrevista & Observação não-participante & Análise de Citações \\
& & Documentos de Biblioteca \\
\hline
\end{tabular}

Fonte: CUNHA (1982).

\subsection{TIPO DE PESQUISA E FORMA DE EXECUÇÃO DAS ATIVIDADES}

Para realização do presente trabalho, houve necessidade de embasamento teórico sobre sistema penitenciário, leitura, biblioterapia e bibliotecas de estabelecimentos prisionais. Para tanto realizou-se extenso estudo envolvendo conceitos, históricos, teses centrais, fundamentações legais, filosóficas, sociológicas e psicoténicas, bem como métodos biblioterapêuticos e aplicações da biblioterapia, e, também, sobre consolidação de bibliotecas em estabelecimentos prisionais.

A revisão de literatura foi realizada em livros, dicionários, enciclopédias, artigos de periódicos, anais de congressos e seminários, páginas de internet relacionadas ao assunto ou relevantes para o trabalho, e documentos em diversos suportes. O referencial teórico analisa os principais conhecimentos existentes sobre os temas abordados aprofundando-se especificamente na biblioterapia e sua relação com as bibliotecas de estabelecimentos prisionais, por se tratar de matérias basilares desse trabalho.

Elaborou-se um plano de atividades a fim de delimitar as metas a serem atingidas ao longo da organização e preparação do projeto de pesquisa. Durante todo os meses de agosto, setembro e outubro foram postos em prática o levantamento bibliográfico, a localização e identificação das fontes de obtenção de dados ou documentos, assim como a aplicação dos 
métodos de pesquisa e levantamentos de dados selecionados, e a consequente análise e interpretação dos resultados obtidos.

Por se tratar essencialmente de dois temas contraditórios no que tange a análises, visto que a biblioterapia se mostra bem mais pesquisada e estudada que bibliotecas de estabelecimentos prisionais, buscou-se observar o uso dos conhecimentos da ciência e da tecnologia (instrumentos, meios e métodos) para se chegar a um consenso de aplicação prática sobre os resultados alcançados. Ao aprofundar no exame dos objetos, tencionou-se explorar e descrever a biblioterapia, sua relação e aplicação em bibliotecas de estabelecimentos prisionais, fazendo-se levantamentos bibliográficos e usando-se técnicas de coleta de dados. $\mathrm{O}$ estudo de caso sobre a biblioteca do Núcleo de Custódia de Brasília (NCB), mais especificamente sobre a biblioteca localizada no Centro de Internamento e Reeducação (CIR), antiga Papuda, vem a complementar toda a pesquisa.

Por ser as prisões do Distrito Federal o ambiente de estudo do trabalho, durante a fase de coleta de dados foram realizadas visitas, quatro num total, ao Complexo Penitenciário da Papuda e ao Centro de Progressão Penitenciária, com a finalidade de conhecer mais a fundo a rotina prisional, as instituições penitenciárias do DF e a existência das bibliotecas em sua estrutura. Em duas visitas se alcançou o êxito, sob intensa vigilância, de adentrar às dependências do Centro de Internamento e Reeducação e à Biblioteca Nova Vida, podendo fazer observações rápidas, porém precisas, sobre todo o ambiente e sua composição, além disso, foram feitas fotografias que figuram, adornam e aperfeiçoam o trabalho.

Ao delimitar a pesquisa, focalizou-se a investigação dos objetivos do trabalho no Centro de Internamento e Reeducação, uma vez que se trata do primeiro presídio a ter sido inaugurado no Complexo Penitenciário da Papuda, segundo a SEJUS, e, fundamentalmente, por ser o local do objeto do estudo de caso.

Os dados alcançados com a observação direta espontânea e não estruturada da Biblioteca Nova Vida foram de grande valia para construção e enriquecimento desse trabalho, permitindo coletar informações e elementos essenciais por meio da verificação in loco, necessárias para complementação do projeto de pesquisa.

Foi elaborado e aplicado um questionário, objetivando coletar dados quantitativos e qualitativos, com perguntas abertas e fechadas, relevantes à pesquisa, em que os detentos usuários da Biblioteca do CIR puderam expor suas opiniões, gostos e dificuldades concernentes à leitura e à biblioteca de estabelecimento prisional. Também, foi realizada uma entrevista semi-estruturada com a bibliotecária coordenadora das bibliotecas dos estabelecimentos prisionais do Distrito Federal. A entrevista teve como objetivo angariar 
informações do profissional bibliotecário, analisando o "outro lado da moeda" no que tange à importância das bibliotecas e da leitura em ambientes prisionais.

Os dados foram analisados quantitativa e qualitativamente. Segundo Ribeiro et al. (2001) a análise quantitativa demonstra em números, de modo fiel e objetivo, fazendo uso de instrumentos específicos capazes de estabelecer relações e causas, levando em conta as quantidades. A análise quantitativa permite a redução de distorções interpretativas e cria ensejo para generalizações e hipóteses. Para Baptista e Cunha (2007), a análise quantitativa possibilita o aumento da "margem de confiabilidade quanto às inferências dos resultados encontrados" (p. 170).

Ao analisar qualitativamente determinado resultado, busca-se investigar, de forma mais íntima, o que os dados tentam traduzir. Chizzotti (apud SILVA, J.,; INOCÊNCIO, 2005, p. 10) afirma que na "pesquisa qualitativa todos os fenômenos são igualmente importantes e preciosos: a constância das manifestações e sua ocasionalidade, a freqüência e a interrupção, a fala e o silêncio". Complementando, Kipnis (2004, p. 59) assegura que "do ponto de vista ontológico, para o pesquisador qualitativo, a realidade é subjetiva, apresentando várias facetas simultaneamente, e apresenta-se a partir das observações dos participantes, de como eles a constroem [...]". Já metodologicamente, a análise qualitativa se faz por meio de um processo indutivo, identificando e relacionando os dados à realidade, sem generalizações.

\subsection{COLETA DE DADOS E APLICAÇÃO DOS QUESTIONÁRIOS}

Dentre os procedimentos existentes e utilizados em pesquisas de trabalhos científicos, acredita-se que a entrevista e o questionário sejam os mais adequados para a linha de exploração desejada, pois este se caracteriza como sendo o método mais utilizado, com fácil e rápida aplicação, barato, que permite atingir uma grande população e, ainda, dá liberdade e tempo ao respondente, apesar de ter algumas desvantagens como fidedignidade das respostas, índice de respostas baixo, não solução de dúvidas por parte do respondente, entre outras. Já a entrevista é considerada o segundo método mais utilizado após o questionário, tendo como vantagem captar reações, sentimentos e possibilita que o entrevistador esclareça alguma pergunta ou terminologia não compreendida pelo entrevistado e a obtenção dos dados é conseguida com riqueza de detalhes. Contudo, a entrevista tem como desvantagens a possibilidade de dupla distorção; de afetar as respostas do entrevistado; necessidade de que o 
entrevistador ganhe a confiança do entrevistado; e, também, os custos são maiores do que o questionário.

O questionário [APÊNDICE A] foi elaborado com dezenove perguntas simples e diretas, de modo a ser respondido facilmente e em pouco tempo. Apenas a primeira e a última pergunta são do tipo aberta, o restante, com exceção da questão de número dez, semi-aberta, são todas do tipo fechado, contendo respostas sim ou não ou de múltipla escolha.

Anteriormente à sua aplicação, em virtude das características particulares da BNV e de seus usuários e, ainda, por fazer relação a órgãos governamentais, os questionários tiveram que ser analisados pelo Juiz da Vara de Execuções Penais do Distrito Federal (VEP), sendo feito um requerimento [APÊNDICE C] para tanto, para que pudesse ser verificado e ajuizado se as perguntas não continham teor ofensivo, violento e/ou erótico. Posteriormente à avaliação e autorização por parte do Juiz da VEP, o mesmo pedido [APÊNDICE D] foi feito à Subsecretaria de Sistema Penitenciário do Distrito Federal (SESIPE), e somente após todo esse trâmite burocrático foi possível entrar em contato com o diretor de ensino do CIR, Hélio Mendes, para se fazer o agendamento do dia da aplicação dos questionários.

Os questionários, então, foram aplicados no dia 3 de novembro de 2009, em uma amostra de 22 internos, selecionados de forma aleatória, do Centro de Internamento e Reeducação do Complexo Penitenciário da Papuda. Todos os selecionados foram prestativos em responder o questionário em sua totalidade. Cabe salientar que no dia e hora marcados por não estar havendo visitação à Biblioteca, os questionários foram aplicados em sala de aula, em duas turmas diferentes, escolhidas pelo senhor Hélio Mendes. Durante a aplicação dos questionários foi possível observar prematuramente que se tratava de turmas de ensino básico, o que pode explicar os possíveis resultados tendenciosos, apresentados a seguir.

Faz-se necessário destacar que no momento da aplicação, os detentos informaram que alguns daqueles que respondiam o questionário não tinham acesso, por determinação da diretoria de ensino do CIR, às dependências da Biblioteca Nova Vida, mas que todos os dias durante o horário do "banho de sol" era disponibilizada no pátio da penitenciária uma Mala do Livro para que todos que desejassem, pudessem ler. Contudo, os mesmos detentos respondentes reclamaram que os documentos da Mala do Livro não podiam ser emprestados, deveriam ser lidos apenas durante o pouco tempo de "banho de sol". 


\subsection{ANÁLISE DOS DADOS}

A compreensão das respostas dos 22 exemplares preenchidos pelos detentos do Centro de Internamento e Reeducação aplicados no dia 3 de novembro de 2009 corresponde à mesma ordem seqüencial das perguntas do questionário [APÊNDICE A]. As variáveis observadas foram idade, escolaridade, frequência de uso da biblioteca, materiais mais procurado, preferências de leitura, benefícios propiciados pela biblioteca, tempo dedicado à leitura, quantidade de documentos lidos, horário e local preferido para leitura, empréstimo de livros, condições após a leitura, leitura como modificadora do comportamento humano, leitura como terapia, importância do auxílio profissional, leitura antes da prisão, dificuldades para se usar a biblioteca e conceito da biblioteca prisional.

\subsubsection{Idade dos detentos entrevistados}

A análise inicial avaliada pelo questionário foi relativa à idade. Como forma de sintetizar a apresentação dos resultados, uma vez que se tratava de uma pergunta aberta, optou-se pela classificação das idades em faixas etárias escalanodas em intervalos triplos, principiando dos 20 aos 22 anos e dando uma maior amplitude após os 31 anos.

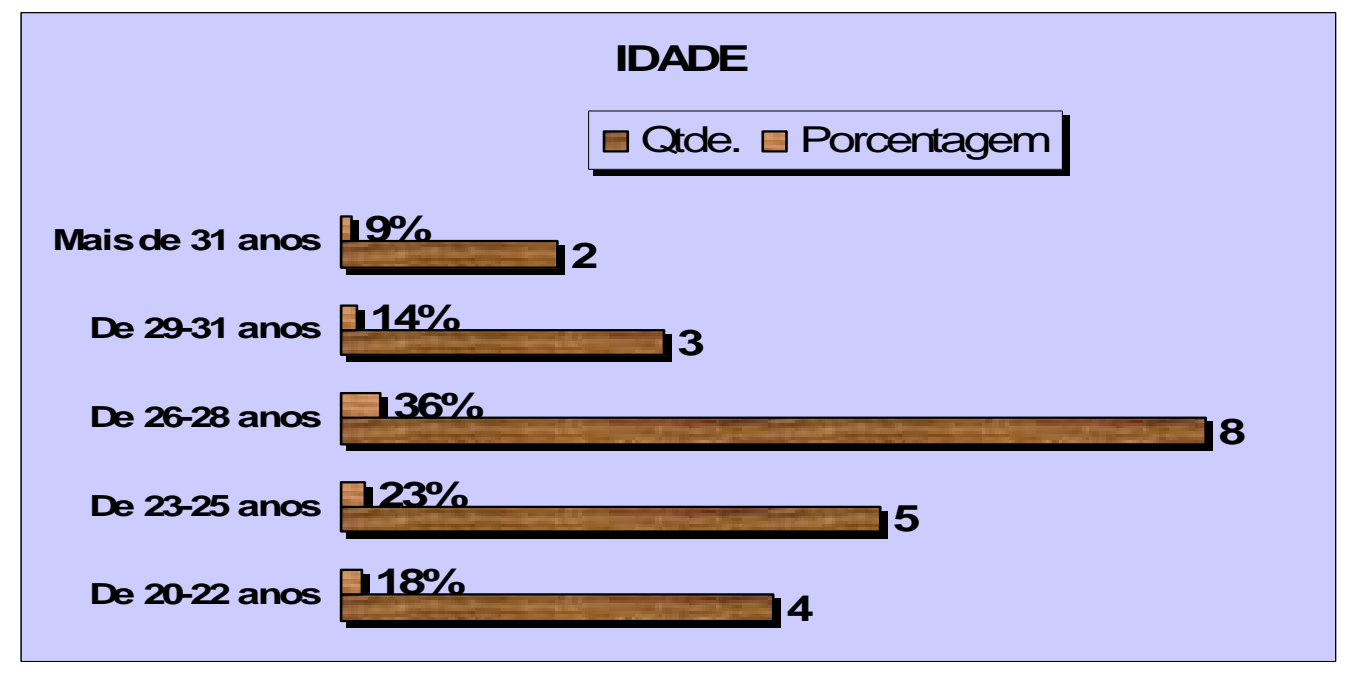

Gráfico 1 - Faixa etária

O gráfico 1 demonstra que dentre aqueles que responderam o questionário, há uma maior concentração de detentos na faixa etária entre 26 e 28 anos, formando um total de $36 \%$. Podendo significar ser estas as idades mais comuns dos detentos que freqüentam a Biblioteca 
do CIR, entretanto, não corresponde necessariamente à faixa etária de maior prática de crimes. Percebe-se ainda que, em relação à idade, a menor quantidade de respondentes são os maiores de 31 anos, correspondendo a um percentual de 9\%. Inferindo-se, com isso, que após os 30 anos, geralmente, os indivíduos já adquiram maior experiência e deste modo tendem a se envolver menos em práticas criminosas.

Viana (2003, online), esclarece, porém, que “[...] a idade do indivíduo não revela exatamente o que ele é ou deveria ser". A idade é importante, mas não é o suficiente para esclarecer o que um indivíduo fez, é ou não capaz de fazer.

\subsubsection{Escolaridade}

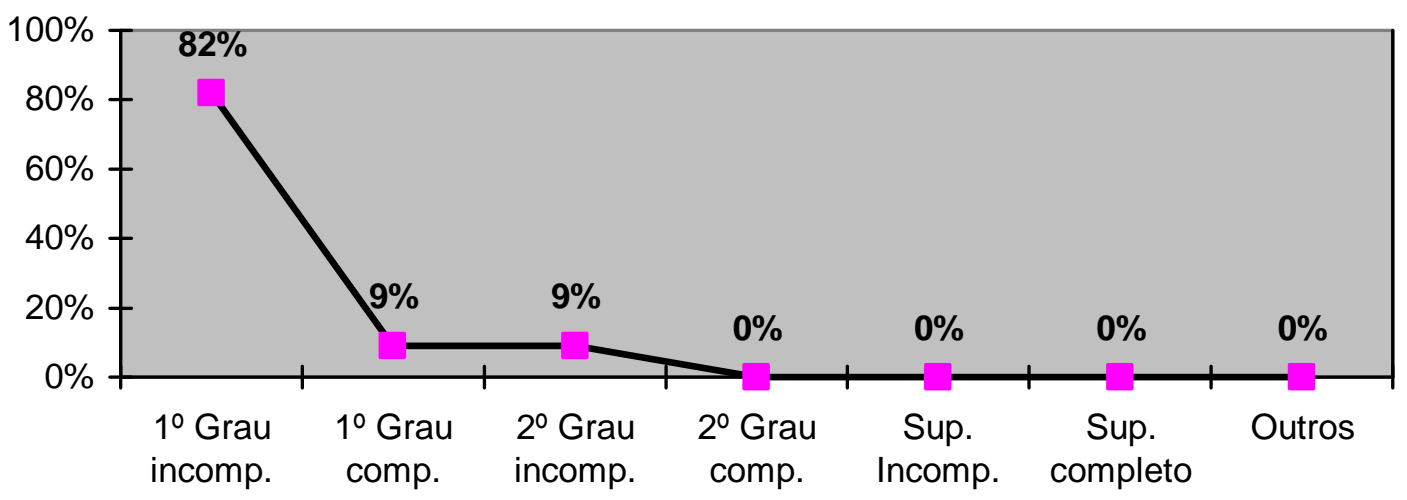

Gráfico 2 - Escolaridade

Na observância relativa ao tempo de estudo dos detentos respondentes do questionário, o gráfico 2 expõe que a maioria absoluta, $82 \%$ no total avaliado, não chegou a terminar o $1^{\circ}$ grau, hoje conhecido com ensino fundamental. De certo modo, comprovando que a população carcerária do CIR seja composta por indivíduos com baixa escolaridade, e refletindo uma realidade evidente nos demais Centros Penitenciários brasileiros.

\footnotetext{
Sabemos que os investimentos em educação também tendem a repercutir fortemente em conquistas de segurança pública. Tem-se boa indicação a respeito quando, por exemplo, comparamos a educação dos presos nos diferentes países com os indicadores médios de escolarização das respectivas populações nacionais. Invariavelmente, observamos que as taxas de analfabetismo são muito superiores entre os presos, quando comparadas com o total de analfabetos em cada país e que os níveis de escolarização presentes na massa carcerária situam-se sensivelmente abaixo dos verificados no conjunto da população (ROLIM, 2008, p. 43).
} 


\subsubsection{Frequência de uso da biblioteca}

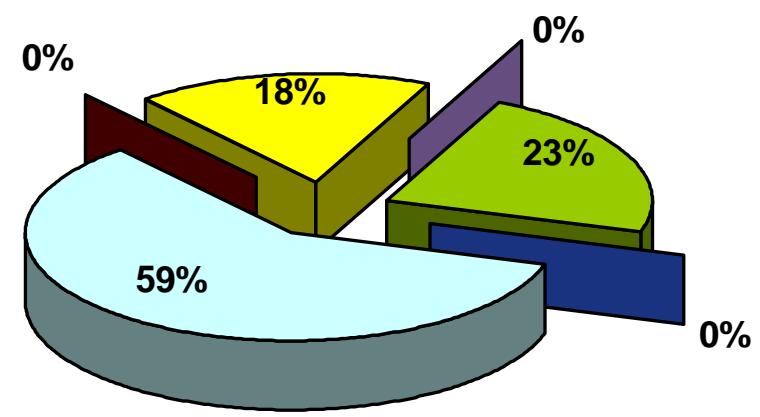

$\begin{array}{lll}\square \text { Até } 3 \text { vezes por semana } & \square \text { Semanalmente } & \square \text { Quinzenalmente } \\ \square \text { Mensalmente } & \square \text { Diariamente } & \square \text { Outros }\end{array}$

Gráfico 3 - Frequência de uso da biblioteca

Quando perguntado sobre a freqüência de visitação dos respondentes à Biblioteca Nova Vida, verificou-se, com o gráfico 3, que a maioria não costumava freqüentá-la, somando $59 \%$ dos entrevistados. Apenas $18 \%$ iam semanalmente e $23 \%$ pelo menos uma vez ao mês.

Tal estatística pode ser explicada pelo fato de nem todos os detentos do CIR poderem fazer uso da Biblioteca por alguma restrição ou ainda pelo pouco tempo de matrícula no Núcleo de Ensino, mas, acima de tudo, pela falta de empenho dos professores em solicitar ou agendar o uso da Biblioteca por parte da turma em que ele vá dar aula.

\subsubsection{Material mais procurado.}

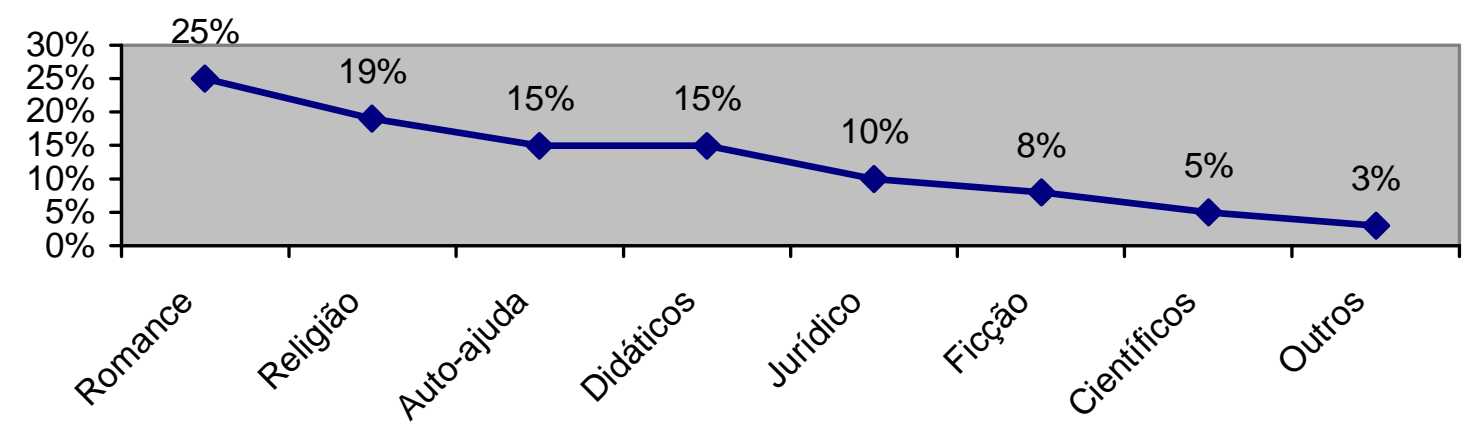

Gráfico 4 - Material bibliográfico mais procurado

Considerando que na questão do questionário relativa aos gêneros mais procurados na Biblioteca Nova Vida deu-se a possibilidade de se poder citar mais de uma resposta e levando em conta que nem todos os respondentes podiam freqüentar o referido setor do CIR no 
momento da pesquisa, computou-se que o material mais procurado são os livros de romance, seguido de documentos religiosos, de auto-ajuda e didáticos, com respectivamente $25 \%, 19 \%$, $15 \%$ e $15 \%$ das respostas dadas.

\subsubsection{O que os questionados preferem ler}

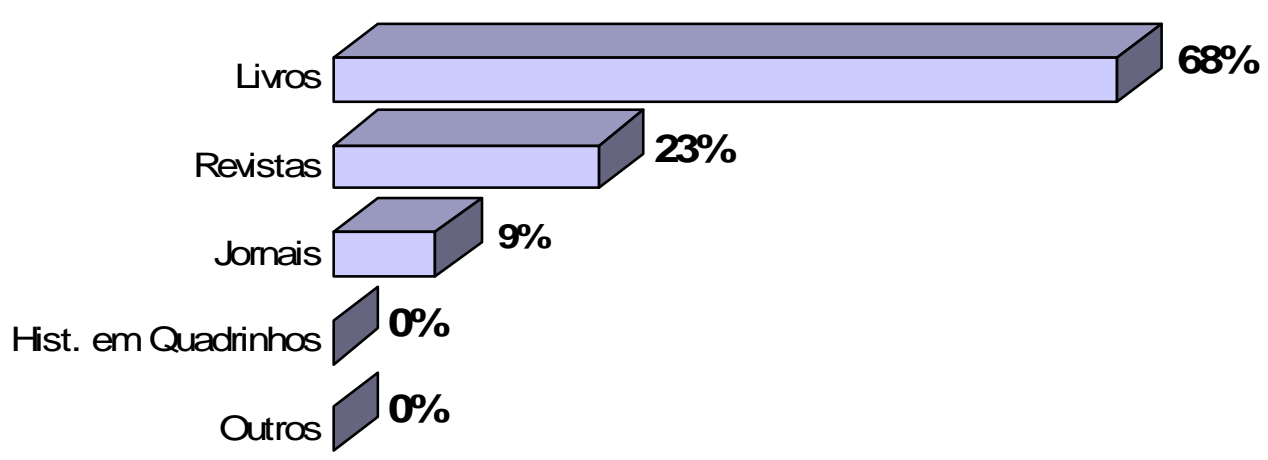

Gráfico 5 - Leitura favorita

Podemos observar, por meio do gráfico 5, que ao serem questionados sobre o que preferiam ler, a maioria dos respondentes, $68 \%$ do total, elegeram o livro como a melhor opção. Confirmando a importância da disponibilização do livro para a população carcerária e do incentivo à leitura. "O livro pode ser sobre romance, aventura, ficção, história, didáticos enfim até ler uma bula numa sala de espera é válido. Sempre que lemos estamos aprendendo mais e mais"(Autor desconhecido). "O livro modifica o leitor e o transforma, [...] tem a capacidade a capacidade de mudar o coração de quem lê"’ (MENDES, J., 2008, p. 53).

As revistas são a segunda opção mais indicada, 23\%, como objeto de leitura mais aprazível. O destaque dado às revistas pode ser explicado pelo fato de serem consideradas importantes "veículos" de entretenimento e lazer, que além trazer em seu conteúdo cultura e informações em geral, mostram parte da realidade perdida pelos detentos. Outrossim, segundo informações do CIR, os detentos costumam usar os periódicos a procura de imagens femininas com intuito de distração lasciva. 


\subsubsection{Determinante que se destaca na imagem da Biblioteca}

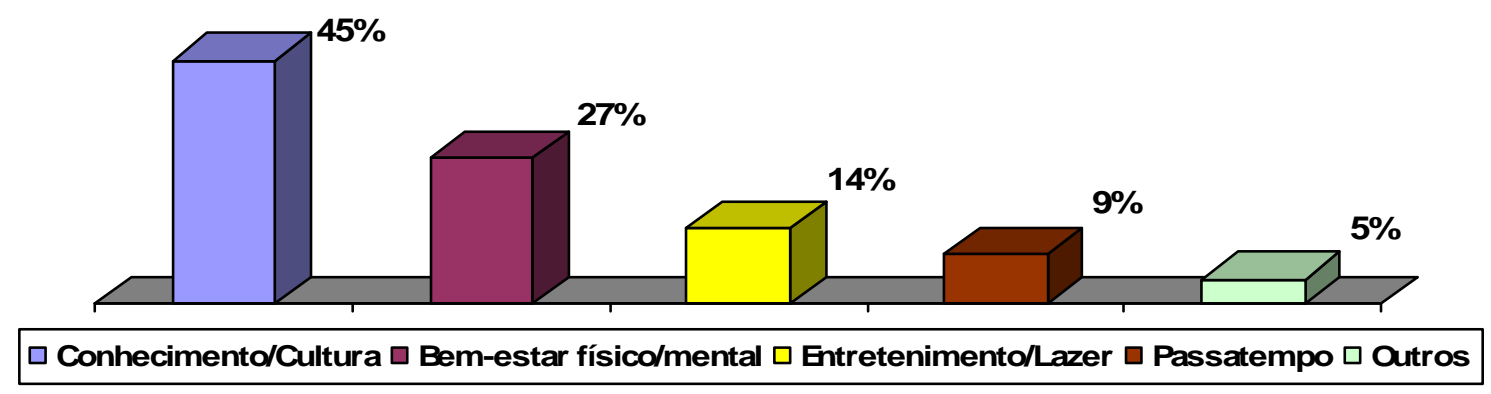

Gráfico 6 - Benefícios da biblioteca

A pergunta 6 do questionário indagava sobre a imagem que os respondentes tinham da biblioteca, como local de leitura. O gráfico 6 apresenta os percentuais das opções disponibilizadas e marcadas no questionário: $45 \%$ costumam ver à biblioteca como um local para adquirir conhecimento e/ou cultura; $27 \%$ acreditam que a biblioteca e, consequentemente, a leitura, proporcionam bem-estar físico/mental; $14 \%$ disseram que biblioteca é um local para se entreter ou se divertir de algum modo; 9\% afirmam ser apenas um local para passar o tempo; e, 5\% citam outras perspectivas.

A biblioteca é o ambiente capaz de abarcar todas as alternativas oferecidas e muitas outras. Embora a análise das respostas dos detentos demonstrarem que a maioria ainda acredita que a biblioteca seja exclusivamente um local de conhecimento e cultura, observa-se que já há uma maior alusão aos diversos benefícios oferecidos pelas instituições bibliotecárias.

\subsubsection{Horas semanais dedicadas à leitura}

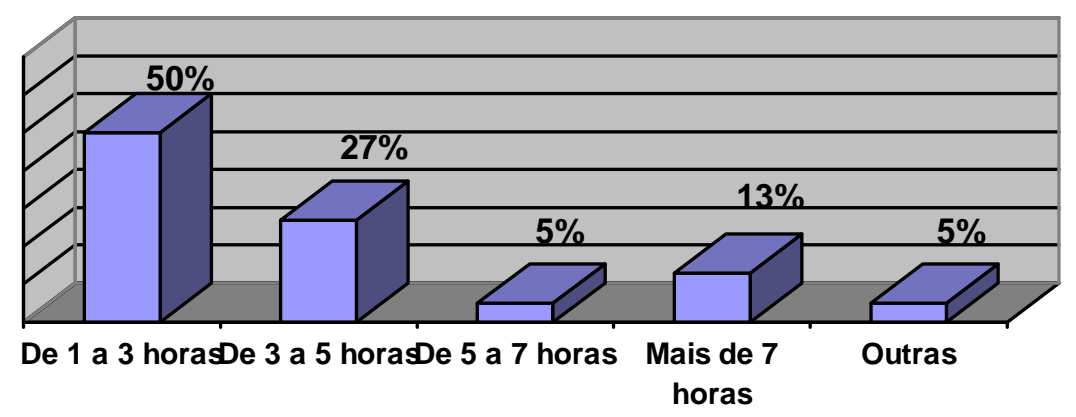

Gráfico 7 - Tempo de leitura semanal 
O gráfico 7 representa as valores percentuais das respostas dos entrevistados, quando questionados sobre a quantidade de horas semanais dedicadas à leitura. A tradução imagética revela que $50 \%$ dos respondentes afirmaram ler de 1 a 3 horas semanais, o que dá menos de trinta minutos diário. Quantidade considerada irrisória quando observada a grande ociosidade dos detentos, porém quando verificado que poucos são os que têm entrada permitida na Biblioteca local e mesmo com a disponibilização da Mala do Livro durante o horário do "banho de sol", a pluralidade prefere realizar outras atividades distintas da leitura, muitas vezes nem se atendo para a disponibilização do serviço bibliotecário, já pode ser ponderado como algo relativo, visto que na sociedade livre há os que não lêem nem isso durante a semana.

Apenas 13\% dos respondentes garantiram ler mais de sete horas semanais. Quantidade ideal para poder aspirar os benefícios de uma boa leitura.

\subsubsection{Livros lidos por mês}

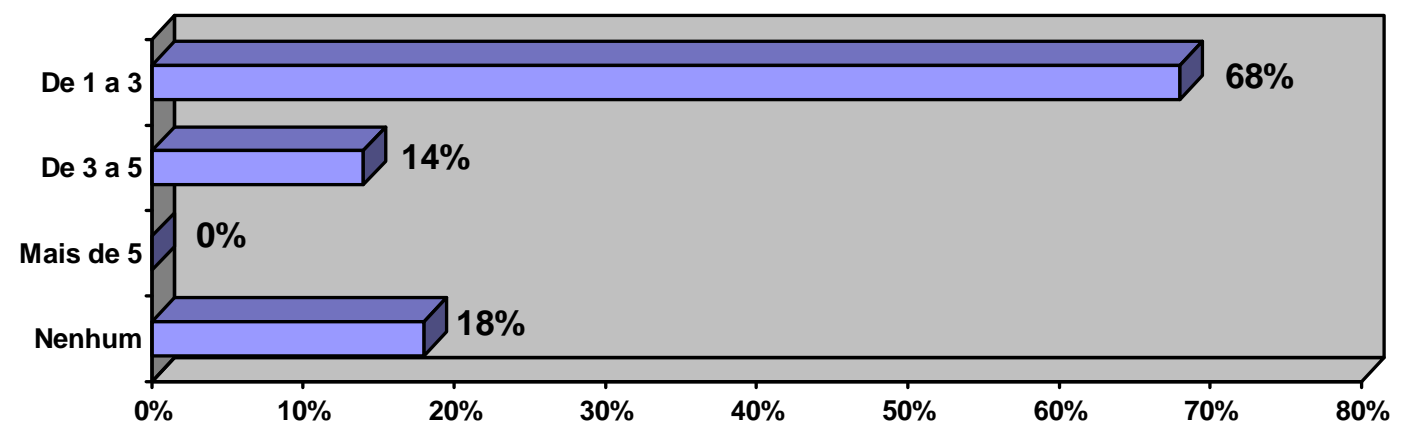

Gráfico 8 - Quantidade de livros lidos por mês

De acordo com as respostas tabuladas, representadas pelo gráfico $8,68 \%$ dos participantes da pesquisa afirmaram que lêem de um a três livros mensalmente; $14 \%$ disseram ler de três a cinco livros; $18 \%$ não costumam ler nenhum livro mensalmente; e, nenhum dos respondentes lê mais de cinco livros em um mês.

Mais uma vez os dados refletem parâmetros presentes na sociedade, já que pesquisas apontam que os brasileiros lêem, em média, 4,7 livros por ano, segundo pesquisa realizada pelo instituto ibope sob a coordenação do Instituto Pró-Livro em 2008; índice bem abaixo de países como Estados Unidos, com cerca de 10 livros, ou Dinamarca, com 15 livros. Quanto maior a exclusão social e menor tempo de estudo, a quantidade de livros lidos reduz vertiginosamente. 
Mendes (2008, p. 152) ao citar Ingarden (1965), entende que "o leitor ativo [...] pode até destruir a obra para produzir uma nova obra, visto que ela tem uma segunda existência e também porque as vivências do autor deixam de existir precisamente no momento em que a obra por ele criada começa a existir nas vivências do leitor".

\subsubsection{Local preferido para leitura}

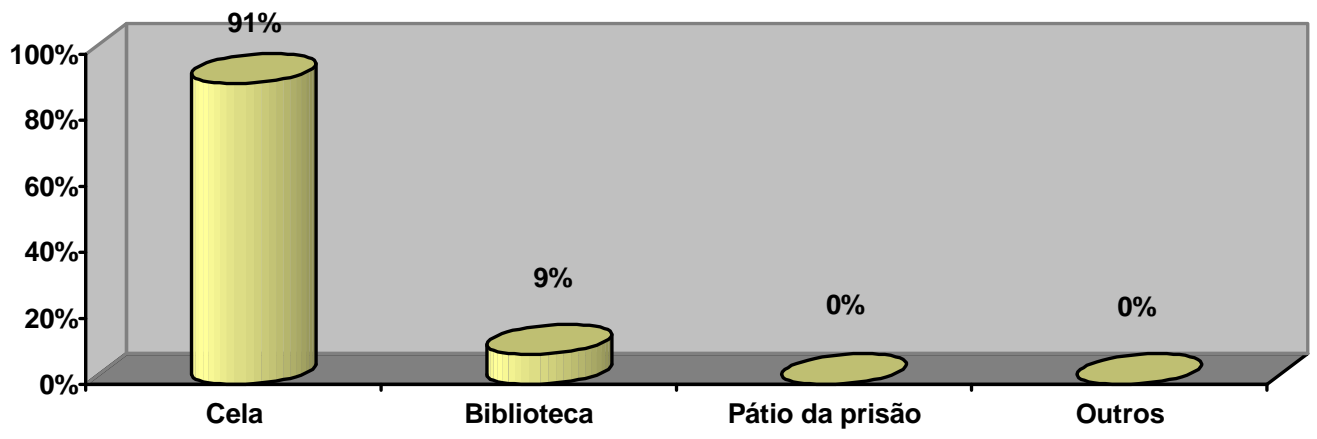

Gráfico 9 - Local favorito para leitura

Entre as poucas opções disponíveis, ao ler, a imensa maioria dos respondentes, $91 \%$, têm como local favorito a cela. A Biblioteca obtém somente $9 \%$ da preferência dos questionados. Os dados podem ser esclarecidos, uma vez que a cela, embora seja um local, na maior parte, sujo, mal ventilado e superlotado, é o local onde o preso passa a maior parte do tempo. Na cela, também, dentro das possibilidades, o preso pode ficar mais à vontade e sob vigilância menos intensa. A biblioteca, nas poucas vezes que o detento costuma frenquentar, é levado pelos professores e devendo servir como apoio pedagógico ao conteúdo da disciplina.

\subsubsection{Empréstimo de livros}

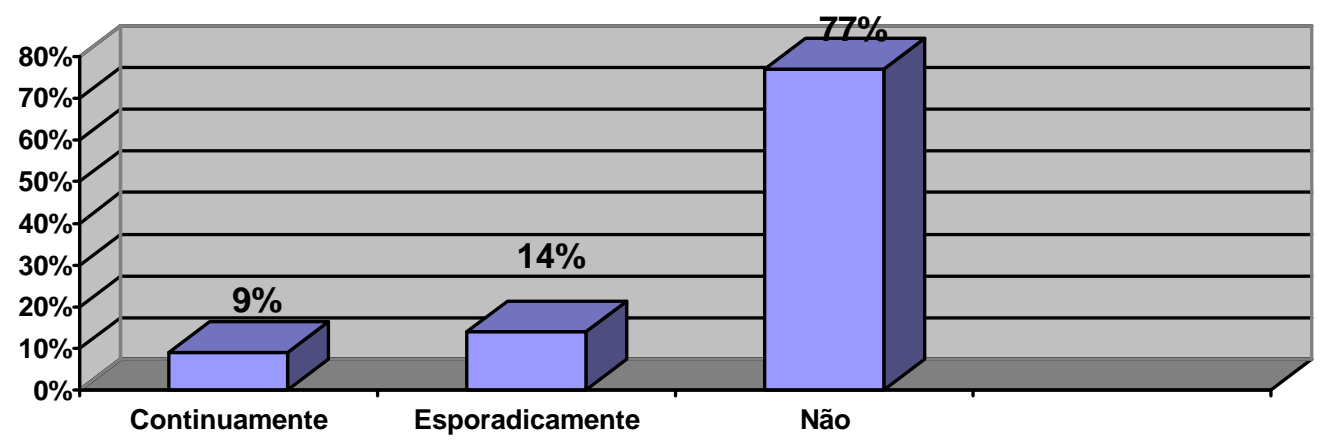

Gráfico 10 - Empréstimo 
$\mathrm{Na}$ pergunta sobre a realização de empréstimo de livros na Biblioteca do CIR, comprovou-se que $77 \%$ dos entrevistados não costumam fazer uso deste serviço. Por ser uma pergunta que pedia a justificativa da resposta em caso da negativa, a maioria dos respondentes da opção escreveram que não pegavam livros emprestado simplesmente por não ter acesso à Biblioteca. Significa, com isso, que há necessidade da diretoria de ensino do CIR de rever a política de acesso dos detentos à Biblioteca Nova Vida.

Dos poucos autorizados, $14 \%$ afirmam usar o serviço de empréstimo poucas vezes e em momentos fortuitos; os $9 \%$ restante afiançam pegar livros emprestados continuamente.

Silva (1997 apud JOHN, 2004, p. 101) abaliza que para que haja a formação e o desenvolvimento de leitores é fundamental "ter acesso aos livros e a outros materiais de leitura, sem os quais tal prática torna-se quase impossível”.

\subsubsection{Condição após leitura.}

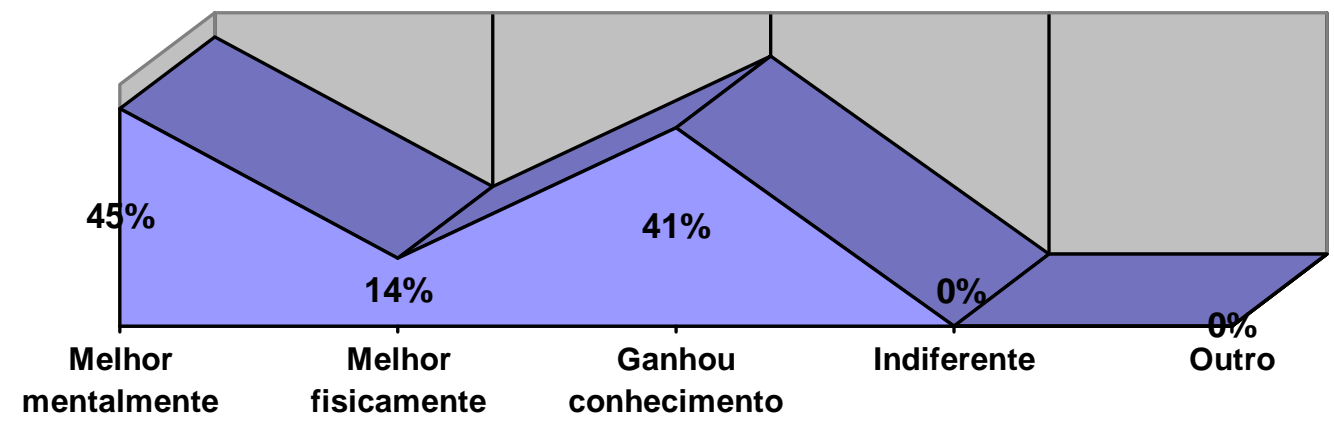

Gráfico 11 - Sentimento pós-leitura

A leitura é a interação do leitor com o livro e vice-versa, possibilitando que o leitor possa compreender o texto e entender a si mesmo. A biblioterapia considera a leitura nas prisões como a libertação dos detentos, indo além dos limites das paredes de concreto ou das altíssimas cercas com arame farpado. A terapia usando documentos literários cuida do corpo e da alma, propicia serenidade, purificação, relaxamento e diversão.

O gráfico 11 possibilita observar que há um equilíbrio nas respostas dos detentos no tocante ao sentimento após ter lido algum texto: $45 \%$ consideram que a leitura os deixam melhor mentalmente, ou seja, mais confortado, mais calmo, mais satisfeito; com um percentual um pouco menor, $41 \%$, outros afirmam que após terem lido adquiriram conhecimento, informação, cultura; e, os outros $14 \%$ se sentem melhor fisicamente. 
John (2004, p. 110) acredita que "a leitura, portanto, não tem para eles apenas uma função terapêutica, mas também e, fundamentalmente, uma função educativa e por isso é uma atividade que deve ser promovida e incentivada na prisão, onde é vista como instrumento para a superação de barreiras, de limitações impostas pelo baixo nível de escolaridade”.

\subsubsection{A leitura influencia o comportamento humano}

\section{Acreditam que a leitura muda o comportamento}

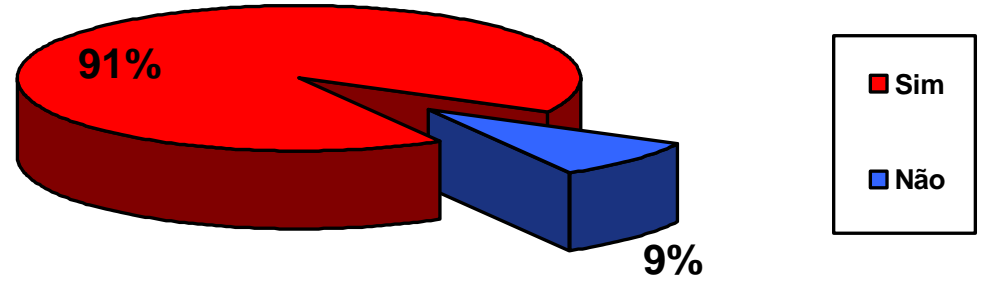

Gráfico 12 - Leitura como modificadora comportamental

Foi questionado aos detentos se os mesmos acreditavam que a leitura poderia alterar a conduta individual. Dentre as respostas, o gráfico 12 revela que $91 \%$ dos entrevistados creem que a leitura possa modificar a conduta humana e somente $9 \%$ não acreditam em tal possibilidade literária.

Mesmo não sendo perguntado aos respondentes do questionário qual gênero literário possibilita mais facilmente a mudança de comportamento, alguns escreveram ao lado da opção escolhida que os livros religiosos e de auto-ajuda, em especial, a Bíblia eram os mais propícios.

Nota-se que ao ingressar no Sistema Penitenciário, o condenado passa a ter conhecimento de seus direitos e, principalmente, de seus deveres. Em ambiente prisional as atitudes devem ser ajuizadas, o bom comportamento é imperioso para o satisfatório andamento dos serviços do Sistema e para que o preso consiga ou mantenha certos direitos, como estudar e trabalhar, com progressão da pena e remissão de dias a serem cumpridos.

John (2004) lembra que em momentos de revolta, não raras as vezes, ou ainda em situações de conflitos emocionais e mentais, o detento procura encontrar algo ou alguém que o sirva de esteio. Neste momento o livro e sua leitura surge como amigo competente para transformar o modo de agir ou pensar do necessitado. 


\subsubsection{Leitura e terapia}

A questão 13 do questionário indagava os respondentes sobre a relação entre leitura e terapia, questionando-os sobre a capacidade da leitura servir de meio ou auxílio terapêutico.

Caldin ((2009, p. 46) caracteriza o que seja terapia:

Entendo por terapia a arte de cuidar do ser, respaldando-me no conceito de holon (o todo) com capacidade regenerante, no benefício do esquecimento e na participação do outro. Não é, então, uma cura, no sentido restritivo da palavra, mas no sentido alargado de busca do equilíbrio e da harmonia do ser total, uma preocupação com o bem estar do ser humano.

\section{Acreditam que a leitura funcione como terapia}

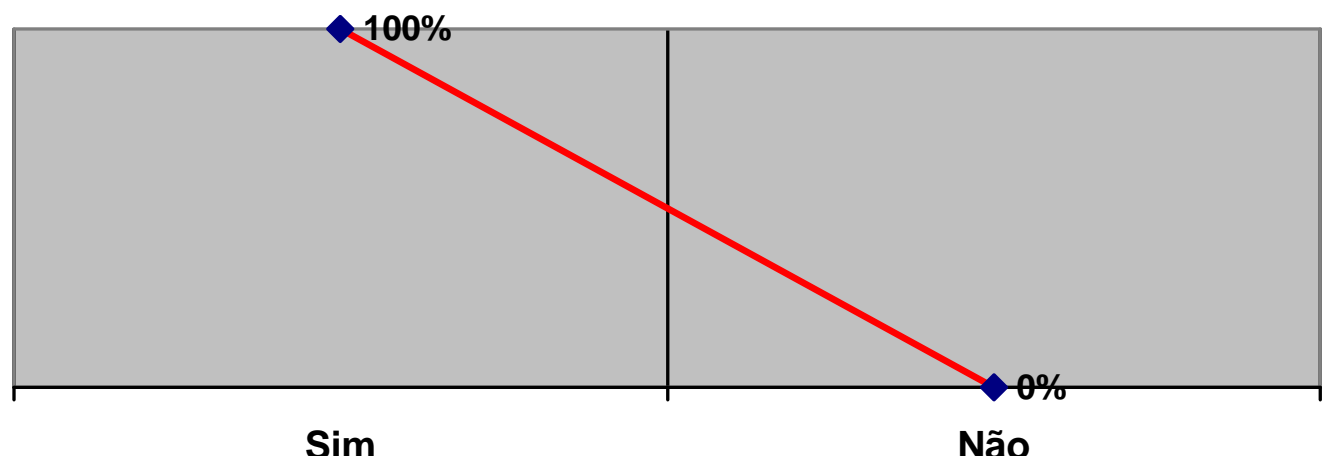

Gráfico 13 - Leitura como terapia

Por meio da análise dos dados, representados pelo gráfico 13, em que a totalidade dos respondentes acreditam que a leitura possa servir como terapia, infere-se que mesmo os indivíduos avaliados não sabendo do que se trate a biblioterapia, eles acabam por confirmar que o uso da leitura como tratamento, auxiliar ou complementar no desenvolvimento mental, físico, emocional e social seja uma realidade.

Caldin (id., p. 79) entende que leitura possa ser considerada um fenômeno e um ato. "Como fenômeno, é o advento espontâneo de essências (lúdicas, romanescas, poéticas, entre outras) e como ato ela diz respeito às representações com as quais podemos refletir aquelas essências". A autora ainda complementa: "Mesmo que o corpo físico se encontre confinado [...] a um presídio, o corpo fenomenal é livre, deixa-se levar pelas palavras lidas” (Ibid.). 


\subsubsection{Importância do auxílio profissional na leitura}

\section{Consideram importante a ajuda profissional na leitura}

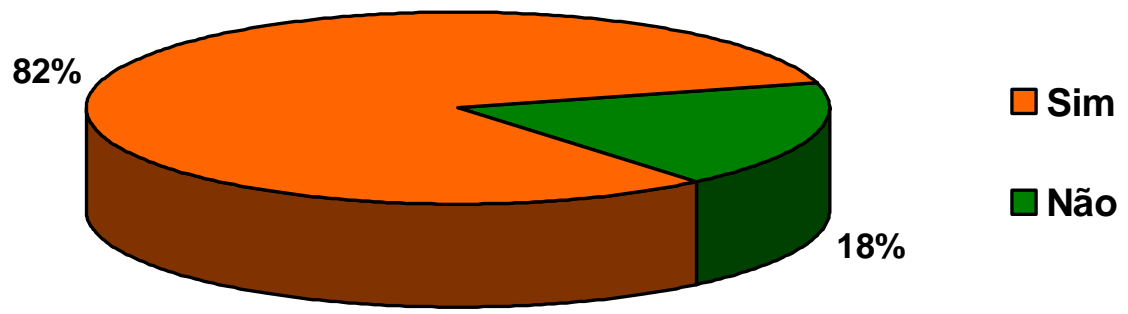

Gráfico 14 - Valoração da assistência profissional para escolher o que ler

Em momentos de decisões e escolhas algumas pessoas optam pela ajuda, por ouvir o palpite de terceiros, entretanto, também existem os que preferem o conflito mental da escolha própria, enfrentando as consequências de suas exclusivas decisões. Nesse enfoque, foi perguntado aos questionados se eles julgavam válido que algum profissional assessorasse na seleção do que se ler: $82 \%$ declararam sim, admitindo que determinado profissional pudesse contribuir; já 18\% contestaram, afirmando que o subsídio profissional não era relevante.

O profissional bibliotecário, por suas atribuições e seu papel social, sopesando ser ele o profissional especializado e capacitado no tratamento da informação e de documentos literários, bem como no incentivo e produção do conhecimento, tem como imputação adicional o estímulo à leitura e sua intermediação. Ao operar como mediador de leitura, o bibliotecário, sobretudo em meio prisional, deve incitar, indicar, sugerir, transmitir o amor pela leitura, em especial a leitura literária (Petit, 1999, p. 10).

"Refletindo sobre a atuação do [...] bibliotecário -, percebemos que sua contribuição como mediador, em um ambiente restrito como a penitenciária, é igual ou superior à atuação de outros mediadores presentes no local - os professores" (OLIVEIRA, D., 2004, p. 112)

\subsubsection{Horário preferido para leitura}

Ouaknin (1996 apud JOHN, 2004, p. 107) determina a leitura como um ato solitário, no qual o indivíduo constrói uma relação mútua, completa e intensa entre o texto e sua subjetividade. $\mathrm{Na}$ individualidade comensal das prisões, onde mesmo acompanhado se está sozinho, o livro constitui um meio de insulamento emancipatório, "distante da multidão de rostos que são, ao mesmo tempo, desconhecidos e sempre os mesmos”. 


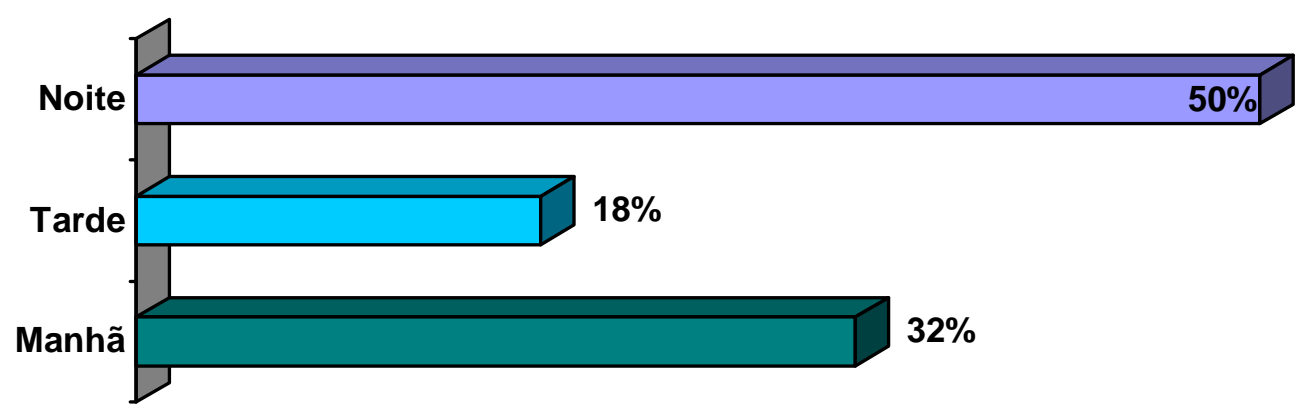

Gráfico 15 - Melhor horário para leitura

Na busca pela entrega à leitura, a fim de encontrar a solidão da concentração, o melhor horário considerado pelos respondentes foi o noturno, com $50 \%$ das respostas, já que a noite o silencio e a calma prevalece na prisão, e a leitura demanda atenção.

Na prisão, além de todos os temores imaginários, a noite representa ainda o temor pelos danos físicos propriamente ditos. É no silêncio da noite que ocorrem, muitas vezes, os abusos sexuais, os "acertos de conta", os espancamentos e até mesmo os assassinatos. Por isso o grupo define a leitura no horário da noite tanto como calmante ou relaxante para induzir ao sono, quanto o instrumento para manter a mente em "estado de alerta", em estado de vigília para ao menos não ser pego de surpresa em algumas dessas situações e assim, ter alguma possibilidade de se defender. A salvação como fim para a leitura, muitas vezes, é a salvação dos suplícios - físicos e psicológicos (JOHN, 2004, p. 108).

\subsubsection{Frequência de leitura antes da prisão}

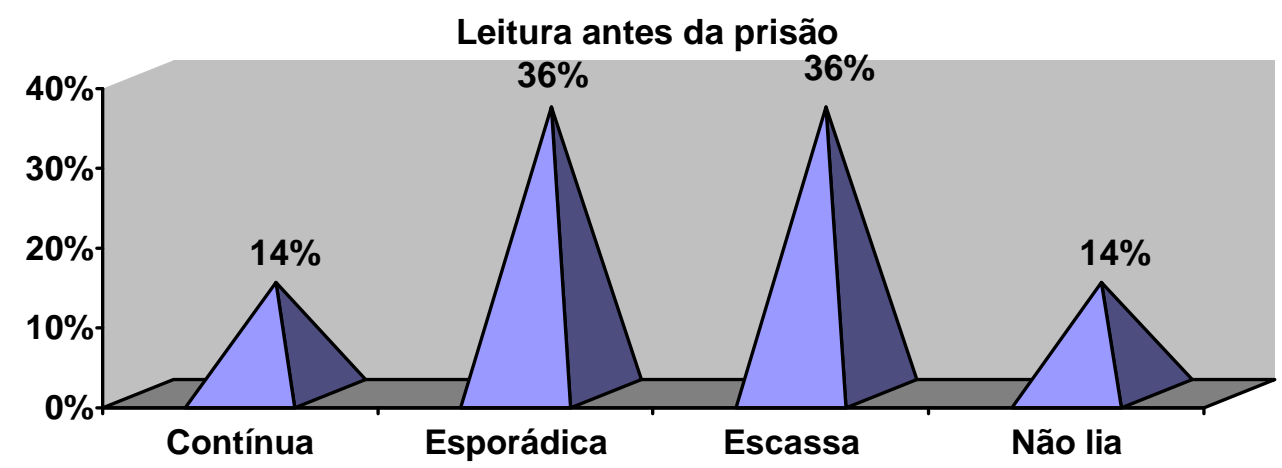

Gráfico 16 - Leitura antes da prisão

Com o passar dos séculos o homem conferiu ao livro e a leitura, visto seus benefícios, o status de modificadores sociais, filosóficos, psicológicos, entre outros. "A leitura é vista como algo exclusivamente benéfico" (JOHN, 2004, p. 100).

Na pergunta do questionário que interrogava sobre os hábitos de leitura dos detentos antes de serem presos, houve dupla coincidência de percentuais, podendo ser observadas no 
gráfico 16. Dentre as opções de respostas a serem escolhidas pelos respondentes, as mais citadas referem-se à leitura ante-prisão 'esporádica' e 'escassa', cada uma com $36 \%$ das respostas tabuladas. As respostas menos citadas, 'leitura contínua' e 'não lia', obtiveram cada uma $14 \%$ do total.

Percebemos que tais resultados demonstram que a maioria dos respondentes não tinha o hábito de leitura continuada antes de serem presos. A prematura abdicação do ensino (gráfico 2), seja por falta de empenho ou por razões diversas, favorece o arrefecimento do interesse literário. A ociosidade prisional, então, oportuniza o aprendizado pelo gosto da leitura, como ocupação do tempo e prevenção de conflitos emocionais e psíquicos.

Não obstante haja um crescimento tímido do número de livros lidos anualmente pelos brasileiros, segundo pesquisa realizada pelo Ibope/Instituto Pró-Livro (2007), infelizmente, nem todos se entregam ao prazer da leitura contínua em sua rotina de vida. A pressa rotineira tende a prejudicar, todavia, não é justificativa para que não se consiga alguns minutos diariamente para ler e receber as benesses de um bom texto. Para John (2004), o livro, então, parece surgir como opção apenas em momentos de impedimentos.

\subsubsection{Maior dificuldade ao usar a biblioteca}

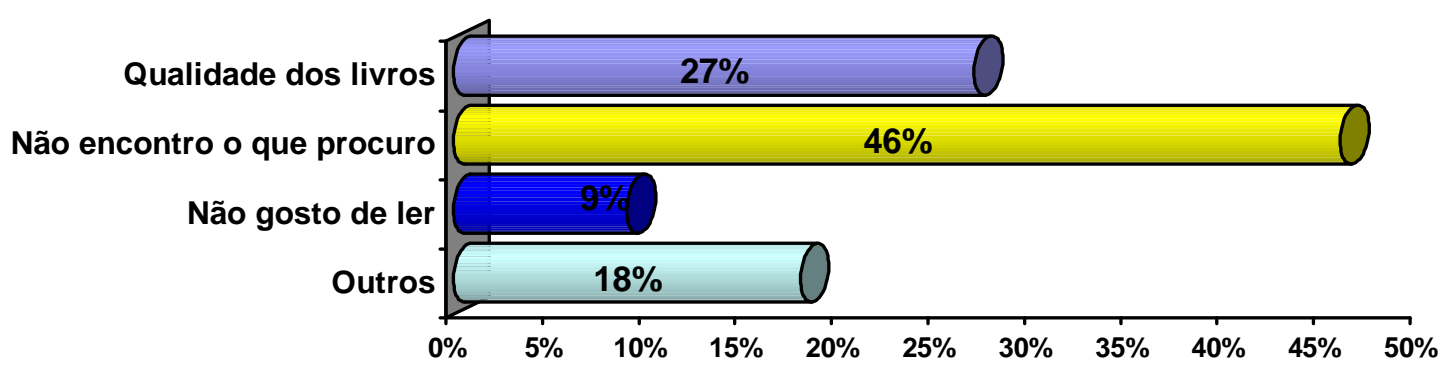

Gráfico 17 - Dificuldade ao usar a biblioteca

Buscando avistar possíveis dificuldades pertinentes ao uso da Biblioteca Nova Vida, o questionário perguntava aos respondentes quais os impedimentos, dentre as alternativas oferecidas, causava maior prejuízo no que tange ao uso pessoal e ao melhor aproveitamento das dependências da Biblioteca.

O gráfico 17 revela que a opção referente à não localização dos livros procurados foi a mais apontada, com $46 \%$ do total das respostas. Dando a entender que os títulos disponíveis no acervo não sejam os documentos que os detentos buscam. Apesar disso, a SESIPE declara 
que a Biblioteca Nova Vida, assim como todas as outras bibliotecas de estabelecimentos prisionais do DF, estão em permanente aperfeiçoamento e avaliação dos títulos que serão disponibilizados aos detentos, tendo como intuito principal a educação.

A qualidade dos livros, com 27\%, seguido da alternativa de resposta 'Outros', $18 \%$ das marcações, correspondem a segunda e terceira, respectivamente, alternativas mais citadas. Somente $9 \%$ dos respondentes confirmaram não gostar de ler como empecilho para usar a Biblioteca.

\subsubsection{Opinião a respeito das bibliotecas em estabelecimentos prisionais}

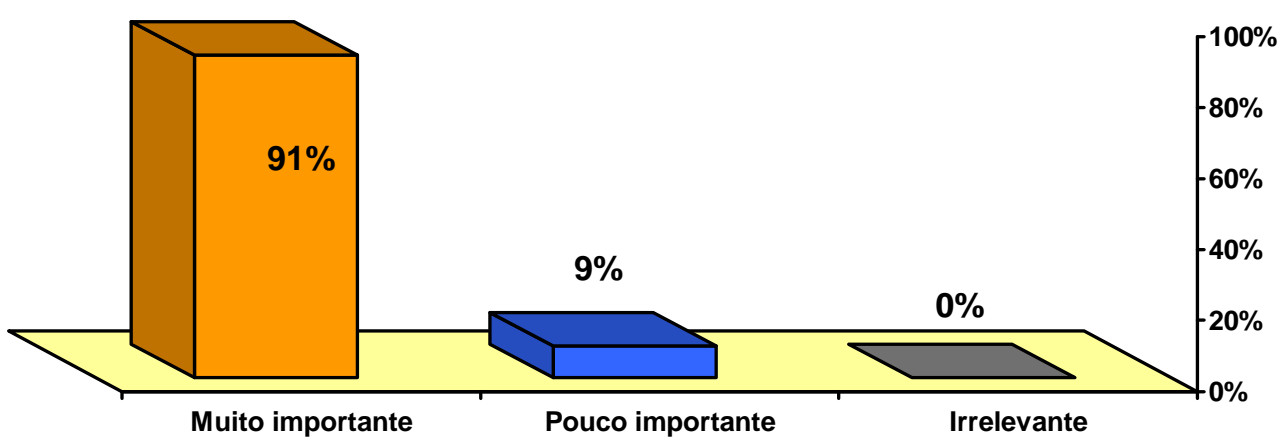

Gráfico 18 - Conceito dos detentos sobre a biblioteca prisional

O gráfico 18 representa o grau de importância atribuído pelos respondentes do questionário às bibliotecas em prisões: $91 \%$ conferem grande valor e 9\%, apenas, impõem menor importância a estas instituições bibliotecárias. Ressalta-se que nenhum dos questionados considerou as bibliotecas prisionais irrelevantes.

Ganho cultural e intelectual, entretenimento e recreação, reforço religioso, mudança comportamental e apoio emocional - denotados pelos gráficos 6, 12 e 13 - são as possíveis vantagens, apontadas pelos detentos, resultantes da presença da biblioteca em estabelecimentos prisionais.

As bibliotecas de estabelecimentos prisionais, segundo a legislação brasileira, são vinculadas às funções educativas e de formação profissional do preso ou do internado (LEP, art. 17). Destaca-se ainda seu amparo informativo, importante para situação dos detentos com a realidade, e recreativo, ocupando o tempo ocioso e entretendo com leitura evasiva.

Durante e após a aplicação dos questionários, percebeu-se a deferência por parte dos detentos às instituições bibliotecárias, em especial às presentes nos estabelecimentos prisionais. Mesmo aqueles que não costumavam freqüentar bibliotecas quando estavam livres, 
manifestaram sua consideração, expondo sua simpatia em fazer uso, ainda que tardia, agora fazendo parte do Sistema Penitenciário.

\subsubsection{Críticas, elogios e sugestões para o que possa ser modificado ou ser feito para melhoria das bibliotecas em estabelecimentos prisionais}

A última pergunta do questionário dava liberdade para que os respondentes pudessem expor seus pontos de vista a respeito das bibliotecas em estabelecimentos prisionais, possíveis modificações, censuras ou aprovações.

Destarte, embora a pergunta fosse de cunho aberto, o que poderia inibir as respostas dos questionados, todos proferiram suas opiniões. A maioria criticava a falta de acesso ou destacava a dificuldade para o ingresso na Biblioteca Nova Vida e a impossibilidade em pegar os livros emprestados. Dentre os depoimentos, ressaltamos as seguintes observações:

\footnotetext{
"Acredito que deva ter mais pessoas que realmente entendam o valor da leitura para nós [presos]. As pessoas precisam ajudar a mudar a rotina do presídio com os livros. Tem muitos presos que 'adoraria' cuidar da biblioteca... ficar responsável por emprestar e recolher os livros. A leitura mudou minha vida!" (Detento “X”).
} "Gostaria de ter mais oportunidades de ida 'na' biblioteca para que possamos
adquirir conhecimento, e consequência disso, nós presos, vamos ocupando nossas
mentes, desviando dos pensamentos criminais" (Detento "Y").

"Sugiro conseguir mais livros e mais atualizados. Também 'era' bom que tivesse livros que ensinasse outras línguas, como francês e espanhol" (Detento “Z”).

“[Recomendo] uma melhor 'organisação' e distribuição [das bibliotecas] no sistema penitenciário e a queda da burocracia para que assim seja facilitado o 'aucance'. Só assim que todos ou boa parte dos presos passam a ter acesso aos livros da biblioteca" (Detento "W").

"Era bom que a gente tivesse mais acesso. Pelo menos um acesso na semana. Quanto mais 'veiz' melhor. Era bom que a gente pudesse levar os livros 'pra' cela, ia ter mais tempo 'pra' ler" (Detento "A").

"Raramente vamos à biblioteca. Não podemos pegar os livros emprestados para levar para cela. A biblioteca tem que ser mais ativa, tem que ajudar mais a gente, tem que ter mais livros." (Detento “B”)

Os depoimentos dos respondentes, transcritos acima, isoladamente e em conjunto, enfatizam o poder da biblioteca para os detentos do Centro de Internamento e Reeducação e, concomitantemente, para os presos de todo o Sistema Penitenciário do Distrito Federal e de 
todos os aparelhos penitenciários brasileiros e/ou internacionais que disponham de biblioteca em sua estrutura, comprovando, da mesma forma, que os detentos não desejam somente que haja bibliotecas nos estabelecimentos prisionais, mas também demonstram interesse em usá-la e se favorecer dos seus serviços e de seus documentos.

A bibliotecária Sharlene Araujo, coordenadora das bibliotecas de estabelecimentos prisionais do DF explica que a dicotomia entre o trabalho de ressocialização das bibliotecas prisionais e o trabalho de disciplina e segurança desempenhados pelos agentes policiais do presídio tende a prejudicar à biblioteca, já que a segurança e disciplina são as prioridades. $\mathrm{O}$ acesso dos detentos aos livros e as dependências da biblioteca, então, estão sujeitos, sempre, a harmônica rotina prisional.

Os [presos] selecionam seus materiais e lêem, com a certeza de que estão sempre acrescentando algo de novo ao seu volume de conhecimento, sempre aprendendo algo positivo que lhes ajude ou lhes permita desenvolver alguma ação. [...] A exemplo do que nos tenta convencer o discurso do governo, a leitura, como a escola, é vista como a chave para a superação das desigualdades sociais (JOHN, 2004, p. 110) 


\section{CONCLUSÃO}

A conclusão [...] não constitui um fím, mas o início de uma aprendizagem e a abertura para um caminho de mudanças e investigação constantes (Germana Rocha).

O presente estudo despontou do propósito de analisar a biblioterapia e as bibliotecas de estabelecimentos prisionais como recursos de vulto nas circunstâncias do Sistema Penitenciário, particularmente, com finalidade de contribuir e provocar reflexões sobre o reconhecimento da leitura como agente terapêutico e ressocializador. Diante de todo o trabalho de pesquisa realizado, e segundo os objetivos propostos estabelecem-se, aqui, as considerações finais.

Ao ser preso o indivíduo passa a ser elemento integrante de uma nova coletividade, repleta de restrições de direitos e desacreditada em seu futuro. No universo dos estabelecimentos prisionais, a obediência e a disciplina são leis; a tensão e o duelo de influências é constância. A adaptação a esse sistema de novas rotinas e de remotas possibilidades é vital para todos os encarcerados.

"A assistência ao preso e ao internado é dever do Estado, objetivando prevenir o crime e orientar o retorno à convivência em sociedade." Expressa na Lei de Execução Penal (Lei no 7.210/84), em seu artigo 10, a escrita estabelece o dever do Estado perante a população carcerária e, também, a toda sociedade brasileira, já que o Sistema Penitenciário tem a incumbência de punir e recuperar, fazendo regressar ao convívio social todos os indivíduos, condenados pela Justiça e presos.

Em meio a uma conjuntura tão carregada quanto das prisões superlotadas, o livro pode ser considerado uma válvula de escape. A biblioteca, com isso, quando considerada o ambiente imperativo para se unir aos prazeres da leitura, torna-se a oportunidade de diminuir a enfadonha rotina, postergando a neurose de se imaginar o tão desejado dia da saída.

Ao determinar que "em atendimento às condições locais, dotar-se-á cada estabelecimento de uma biblioteca, para uso de todas as categorias de reclusos, provida de livros instrutivos, recreativos e didáticos" (Art. 21), a LEP corrobora com o conceito de que a biblioteca em estabelecimentos prisionais possibilita não somente assistência educacional, mas também distintos préstimos na missão governamental de ressocialização.

Observa-se que apesar de notável, as bibliotecas de estabelecimentos prisionais ainda não ganharam o reconhecimento intrínseco e inevitável a estas instituições. Aliada a programas específicos serve de apoio educacional recomendado pela LEP - Seção V, "Da 
assistência educacional" -, pelo Plano Nacional de Educação (PNE) e, de certo modo, pela Lei de Diretrizes e Bases da Educação (LDB), quando cita a Educação de Jovens e Adultos (EJA), mesmo não fazendo menção a educação nas penitenciárias. Unida a planos terapêuticos e de reabilitação como a biblioterapia, essas bibliotecas se fazem, extraordinariamente, imprescindíveis.

As bibliotecas de estabelecimentos prisionais ratificam sua proeminência diante do contexto penitenciário brasileiro. Não obstante a dificuldade de instauração, funcionamento e manutenção, elas comprovam seus benefícios ao incentivar a leitura, a escrita, o acesso à informação e desenvolvimento educacional e cultural. Um espaço útil "no processo de reinserção dos reclusos, acompanhando assim uma nova visão estratégica do espaço de reclusão no seu todo" (EIRAS, 2007, p. 6). "Devem incluir em seu planejamento cursos, palestras, apresentações artísticas, concursos literários, etc, procurando despertar vocações ou desenvolver aptidões" (LIMA, S., 2002, p. 89).

A biblioterapia deve ser considerada um instrumento de auxílio, recuperação ou prevenção de conflitos emocionais e físicos, fazendo uso da leitura como elemento curativo ou preventivo, cuidando do corpo e da alma. A leitura cuidando do ser, usufruindo e exercitando a percepção, a sensação, a imaginação, a memória, a linguagem, o raciocínio e a intuição intelectual, como afirma Caldin (2009, p. 53).

A biblioterapia é bem mais que o simples uso de recursos literários. Vale-se de todos os meios instrutivos e recreativos, sobretudo dos sentimentos e sentidos humanos para cuidar do próprio ser humano. O método biblioterapêutico, no entanto, deve ser visto como técnica terapêutica contempladora de sentidos, de relevância social, complementar e preventiva que intenta contribuir para qualidade de vida dos que padeçam de algum sofrimento psíquico, emocional, moral, físico ou institucional.

O bibliotecário, naturalmente considerado o profissional que atuará ativamente, seja como mediador ou auxiliando outros profissionais, no processo biblioterapêutico deve transparecer qualidades importantes, como boa comunicação, flexibilidade, simpatia, interesse, entendimento psicológico do ser humano, compreensão dos problemas enfrentados pelos indivíduos e capacidade de formular hipóteses e relacionamentos destes problemas com a seleção de programas que visem o bem-estar do outro.

De acordo com a análise dos dados relativos às bibliotecas de estabelecimentos prisionais do Distrito Federal, sobretudo da Biblioteca Nova Vida do Centro de Internamento e Reeducação do Complexo Penitenciário da Papuda, considera-se que estas instituições apresentam desafios conflitantes com o seu papel político-pedagógico. Sendo indispensável 
que mais investimentos sejam disponibilizados e aplicados na melhoria da infraestrutura de todas elas. A atualização do acervo, a aquisição de equipamentos de informática e de novos mobiliários são exemplos de problemas básicos a serem resolvidos.

Com base no questionário aplicado aos detentos do CIR, o principal impedimento delineado em relação à biblioteca respalda-se na falta ou no insuficiente acesso dos presos à Biblioteca Nova Vida. Observadas as questões relativas à segurança, sugere-se criar rotinas semanais de uso das dependências da biblioteca nos dias de aula, com marcações previamente agendadas. Cada professor seria responsável por levar os alunos-detentos de determinada turma à Biblioteca, utilizando práticas educacionais concernentes à disciplina e incentivando a leitura. Aos detentos não matriculados no Núcleo de Ensino, recomenda-se a manutenção da disponibilização da Mala do Livro no pátio da penitenciária nos horários de "banho de sol" e a permissão do empréstimo dos documentos deste serviço. Dando possibilidade para que o apenado realize a leitura no momento e local mais adequado para cada um.

Com a análise dos questionários, também foi possível perceber que há um considerável interesse na leitura por parte da maioria dos presos, seja para aquisição de conhecimento, cultura, por prazer, entretenimento ou unicamente para passar o tempo. Ainda que se tenha criado uma política de incentivo à leitura ao disponibilizar a Mala do Livro no pátio da prisão nos horários de "banho de sol", não exclui a necessidade de promoção ao uso da Biblioteca Nova Vida, uma vez ser ela o local ideal para prática da leitura e do aprendizado; também, a Mala do Livro comporta pouca quantidade de documentos, impossibilitando grandes variações de títulos e de escolha, visto a grande quantidade de detentos; além disso, no horário de "banho de sol" torna-se difícil a leitura em virtude do barulho e movimentação constante dos demais presos.

Mesmo que não tenha sido citada no questionário a palavra 'biblioterapia', nota-se com a análise das respostas dos detentos que a leitura sirva como competente método terapêutico de conduta, extremamente apropriado em locais com intenso dinamismo cultural, ideológico e social como o da prisão, com suas leis e códigos próprios, em que a tensão é perene. Lembrando que a realização eficaz da biblioterapia em instituições prisionais depende da existência das bibliotecas nos mesmos locais.

Dessa forma, a leitura, contribui para a ressocialização como força vitalizadora de excelência capaz de transformar o leitor-detento, livrando-o do peso da realidade vivenciada. Como afirma John (2004, p. 113), cada nova leitura e assim estamos num processo de contínua transformação e aprendizagem. A leitura abre portas antes jamais imaginadas e cada texto, cada livro, 
cada leitura vão despertando em nós a vontade de vislumbrar novos horizontes e nada mais é capaz de nos aprisionar. O que faremos com estas leituras, se as usaremos para o bem ou para o mal, para nós mesmos ou para os outros, somente cada leitor pode determinar. Certo é apenas que não somos mais os mesmos depois que nos entregamos ao ato de ler.

Embora muitas opiniões contrárias, visto a situação preocupante do Sistema Penitenciário brasileiro, a ressocialização do preso é possível. Leis e recursos existem para tanto. Obviamente, a leitura, a biblioterapia, as bibliotecas de estabelecimentos prisionais e, até mesmo, os bibliotecários prisionais não devem ser qualificados como a "salvação da pátria" na recuperação dos encarcerados, devem ser vistos, sim, como opções, que juntas, podem maximizar a concretização dos objetivos de reeducação e reinserção social. Meios irrefutáveis de assistência, restituição e regeneração à "pessoas segregadas e afastadas temporariamente do convívio social e talvez por isto, esquecidos da maioria das falas, estudos e pesquisas feitas neste país" (SILVA, J.,; INOCÊNCIO, 2005, p. 11). 


\section{REFERÊNCIAS}

ALSTON, Edwin F. Bibliotherapy and psychotherapy. Library Trends, Illinois, v.11, n. 2, p. 159-176, oct. 1962.

ALVEIRINHO, Ana; LOUSADA, Alexandre. Bibliotecas especiais: para uma igualdade de acesso. 2006. Disponível em: <www.geocities.com/clicaele/22.pdf>. Acesso em: 21 nov. 2008 .

ALVES, Maria Helena Hess. A aplicação da biblioterapia no processo de reintegração social. Revista Bras. Biblioteconomia e Documentação, v. 15, n.1/2, p. 54-61, jan./jun. 1982.

AMARAL, Sueli Angelica do. Serviços bibliotecários e desenvolvimento social: um desafio profissional. Ciência da Informação, Buenos Aires, Arg., v. 24, n. 2, p.35-54, 1995.

AMERICAN LIBRARY ASSOCIATION. Guidelines for Library Service to Prisoners. Chicago: Association Of Specialized And Cooperative Library Agencies, 1992.

AMERICAN LIBRARY ASSOCIATION. Guidelines for Library Service to Prisoners. 2 ed. rev. Londres: Library Association Publishing, 1997.

ARAÚJO JUNIOR, Marcondes de Sousa. O discurso da imprensa sobre o Complexo Penitenciário da Papuda em Brasília, de 1979 aos nossos tempos. Brasília, 2005, 52 p. Monografia (Bacharelado em História). Centro Universitário de Brasília, 2005. Disponível em: $\quad$ Lhttp://www.monografias.brasilescola.com/historia/o-discurso-imprensa-sobrecomplexo-penitenciario-papuda-.htm>. Acesso em: 14 out. 2009.

ASSOCIAÇÃO BRASILEIRA DE NORMAS TÉCNICAS. NBR6022: apresentação de artigos em publicações periódicas. Rio de Janeiro, 1994.

ASSOCIAÇÃO BRASILEIRA DE NORMAS TÉCNICAS. NBR6023: informação e documentação - referências - elaboração. Rio de Janeiro, 2000.

ASSOCIAÇÃO BRASILEIRA DE NORMAS TÉCNICAS. NBR6024: numeração progressiva das seções de um documento. Rio de Janeiro, 1989.

ASSOCIAÇÃO BRASILEIRA DE NORMAS TÉCNICAS. NBR6027: sumário. Rio de Janeiro, 1989. 
ASSOCIAÇÃO BRASILEIRA DE NORMAS TÉCNICAS. NBR10520: informação e documentação - apresentação de citações em documentos. Rio de Janeiro, 2001.

ASSOCIAÇÃO BRASILEIRA DE NORMAS TÉCNICAS. NBR14724: informação e documentação - trabalhos acadêmicos - apresentação. Rio de Janeiro, 2001.

ASSOCIAÇÃO BRASILEIRA DE NORMAS TÉCNICAS. NBR6028: resumos. Rio de Janeiro, 1990.

BACHERT, Cristina Maria D’Antona. Estratégias da biblioterapia de desenvolvimento aplicadas na orientação de problemas de disciplina. Campinas, S.P., 2006. Dissertação (Mestrado em Psicologia). Pontifícia Universidade Católica de Campinas, 2006. 181 p.

BAPTISTA, Sofia Galvão; CUNHA, Murilo Bastos. Estudo de usuários: visão global dos métodos de coleta de dados. Perspectivas em Ciência da Informação, v. 12, n. 2, p. 168184, maio/ago. 2007.

BARBOSA, Antônio Rafael. Os desafios do sistema penitenciário brasileiro. Ciência Hoje, v. 40, p. 18-23, jun. 2007.

BEATTY, William K. A historical review of bibliotherapy. Library Trends, Illinois, v. 11, p. 106-117, oct. 1962.

BECCARIA, Cesare. Dos delitos e das penas. São Paulo: Martin Claret, 2000.

BENTES PINTO, Virgínia. A biblioterapia como campo de atuação para o bibliotecário. Transinformação, Campinas, v. 17, n. 1, p. 31-43, jan./abr., 2005.

BENTES PINTO, Virgínia. Biblioterapia: a leitura que ajuda a sarar. Jornal o Povo: Fortaleza, 2002. Disponível em: 〈http://www.noolhar.com/opovo/opiniao/189050.html>. Acesso em: 22 ago. 2009.

BENTES PINTO, Virgínia et al. O uso da biblioterapia como coadjuvante no tratamento de crianças portadoras de câncer do Hospital Albert Sabin. In: INFO 95, 1995. Proceedings... Havana: IDICT, 1995. 
BRAGA, Jhonei B. de Souza; SANTOS, Raquel Pimentel Dos. Biblioterapia aplicada às crianças hospitalizadas no Hospital Regional de Ceilândia. Brasília, 2006. 69 p. Monografia (Graduação em Biblioteconomia). Departamento de Ciência da Informação e Documentação, Universidade de Brasília, Brasília, 2006.

BRASIL. Ministério da Educação. Instituto Nacional de Estudos e Pesquisas Educacionais Anísio Teixeira. Plano Nacional de Educação. Brasília, DF: Ministério da Educação, 1997.

BRASIL. Ministério da Justiça. Conceituação e classificação de Estabelecimentos Penais. [200-]. Disponível em: <http://www.mj.gov.br/depen/data/Pages/MJD574E9CEITEMIDAB2EF2D92895476E8516E 63C78FC7C4CPTBRIE.htm>. Acesso em: 21 nov. 2008.

BRASIL. Ministério da Justiça. Execução penal. [200-]. Disponível em: <http://www.mj.gov.br/main.asp?ViewID=\%7BE9614C8C\%2DC25C\%2D4BF3\%2DA238\%

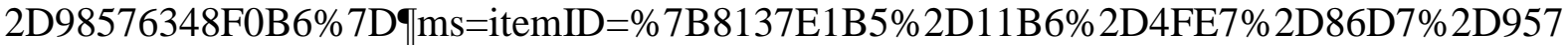
1348AF935\%7D;\&UIPartUID=\%7B2868BA3C\%2D1C72\%2D4347\%2DBE11\%2DA26F70 F4CB26\%7D>. Acesso em: 21 nov. 2008.

BRASIL. Ministério da Justiça. Matérias especiais. 2006. Disponível em: <http://www.mj.gov.br/noticias/especiais/2006/julho/mtesp210706-presidios.htm>. Acesso em: 18 nov. 2008.

BRASIL. Presidência da República. Casa Civil. Subchefia para Assuntos Jurídicos. Lei no 7.210, de 11 de julho de 1984. Institui a lei de execução penal. Diário Oficial da União, Poder Executivo, Brasília, DF, 13 jul. 1984.

BRASIL. Presidência da República. Casa Civil. Subchefia para Assuntos Jurídicos. Lei no 9.394, de 20 de dezembro de 1996. Estabelece as diretrizes e bases da educacional nacional. Diário Oficial da União, Poder Executivo, Brasília, DF, 23 dez. 1996.

CALDIN, Clarice Fortkamp. A leitura como função terapêutica: biblioterapia. Enc. Bibli: Rev. Eletrônica de Biblioteconomia e Ci. Informação. n. 12, p. 32-44, 2001.

CALDIN, Clarice Forkamp. A poética da voz e da letra na literatura infantil: leitura de alguns projetos de contar e ler para crianças. Florianópolis, 2001. 261 p. Dissertação (Mestrado em Literatura). Universidade Federal de Santa Catarina, 2001.

CALDIN, Clarice Fortkamp. Leitura e terapia. Florianópolis, 2009. 216 p. Tese (Doutorado em Literatura). Universidade Federal de Santa Catarina, 2009. 
CHACÓN ALVARADO, Lucía. Acceso a la Información para los Prisioneros. 1993. Disponível em: <http://www.una.ac.cr/bibliotecologia/boletinbiblioteca/1993/Acceso.doc>. Acesso em: 21 ago. 2009.

CHARTIER, Roger. A aventura do livro: do leitor ao navegador. Tradução de: Reginaldo Carmello Corrêa de Moraes. São Paulo: Editora Unesp/Imprensa Oficial do Estado de São Paulo, 1999.

COSTA, Marco Antonio F. da; COSTA, Maria de Fátima Barrozo da. Metodologia da pesquisa: conceitos e técnicas. Rio de Janeiro: Interciência, 2001. 135 p.

CUNHA, Murilo Bastos da. Metodologias para estudos de usuários de informação científica e tecnológica. R. Bibliotecon. Brasília, v. 10, n. 2, p. 5-19, jul./dez. 1982.

CYSNE, M.R.F.P. Biblioteconomia: dimensão social e educativa. Fortaleza: UFC, 1993.

DANIÉLOU, Jean e MARROU, Henri. Nova História da Igreja: dos primórdios a São Gregório Magno. Tradução Dom Paulo Evaristo Arns OFM. In: ROGIER, L.J; Aubert, R.; Knowles, M. D. Nova História da Igreja, Petrópolis: Vozes, 1984.

DEWEY, J. Experiência e educação. São Paulo: Ed. Nacional, 1971.

DISTRITO FEDERAL. Decreto $\mathrm{n}^{\circ}$ 26.637, 16 de março de 2006. Regulamenta a implantação e o funcionamento da Biblioteca Nova Vida no Complexo Penitenciário da Papuda, criada pela Lei ${ }^{\circ}$. 1.663, de 15 de setembro de 1997, e dá outras providências. Diário Oficial do Distrito Federal, Poder Executivo, Brasília, DF, 17 mar. 2006.

DISTRITO FEDERAL. Lei $\mathrm{n}^{\circ}$ 1.663, de 15 de setembro de 1997. Cria a biblioteca Nova Vida no complexo penitenciário da Papuda e dá outras providências. Diário Oficial do Distrito Federal, Poder Executivo, Brasília, DF, 29 set. 1997.

DISTRITO FEDERAL. Secretaria de Estado de Desenvolvimento Urbano e Habitação. Dinâmica e estrutura populacional do DF. [200-]. Disponível em: $<$ http://www.distritofederal.df.gov.br/sites/100/155/PDOT/doct06.htm>. Acesso em: 14 out. 2009.

DISTRITO FEDERAL. Secretaria de estado de justiça, direitos humanos e cidadania. FUNAP-DF: Recursos disponíveis para o processo educacional. [200-]. Disponível em: <http://www.sejus.df.gov.br/paginas/funap/funap_04.htm>. Acesso em: 28 nov. 2008. 
EIRAS, Bruno Duarte. Uma janela para o mundo: bibliotecas e bibliotecários em meio prisional. 2007. Disponível em: <www.apbad.pt/Downloads/congresso9/COM59.pdf>. Acesso em: 10 abr. 2009.

ELSER, Helen. Bibliotherapy in practice. Library Trends, Spring, v.30, n.4, p. 647-659, 1982.

FERREIRA, Danielle Thiago. Biblioterapia: uma prática para o desenvolvimento pessoal. Educação Temática Digital, Campinas, v. 4, n. 2, 2003. Disponível em: <http://www.bibli.fael.unicamp.br/etd/biblioterapia.pdf>. Acesso em: 10 nov. 2008.

FIGUEIREDO, Nice Menezes. Estudo de usuários como suporte para planejamento e avaliação de sistemas de informação. Ciência da Informação, Brasília, v. 14, n. 2, p. 127 135, jul./dez. 1985.

FÍLON DE ALEXANDRIA. In Infopédia. Porto, Portugal: Porto Editora, 2003. Disponível em: < http://www.infopedia.pt/\$filon-de-alexandria>. Acesso em: 15 ago. 2009.

FISCHBERG, Josy; DUARTE, Rosália Maria. Criança e jornalismo: um estudo sobre as relações entre crianças e mídia impressa especializada infantil. Rio de Janeiro, 2007. 151 p. Dissertação (Mestrado em Educação). Pontifícia Universidade Católica do Rio de Janeiro, 2007.

FONTE, Nilce Nazareno da. Pesquisa Científica: o que é como se faz. [199?]. Disponível em: <http://people.ufpr.br/ nilce/metodolog.\%20pesquisa\%20cientifica.doc>. Acesso em: 23 set. 2009.

FOUCAULT, M. Vigiar e punir: história da violência nas prisões. Petrópolis: Vozes, 1987.

FREIRE, P. Educação como prática da liberdade. Rio de Janeiro: Paz e Terra, 1983.

FREUD, Sigmund. Os chistes e suas relações com o inconsciente. Tradução de Margarida Salomão. Rio de Janeiro: Imago, 1969.

GALVÃO, M. C. B. Construção de conceitos no campo da ciência da informação. Ciência da Informação, v. 27, n. 1, p. 46-52, jan./abr. 1998. 
GARCIA-PEREZ, Maria Sandra. Um acercamiento a las bibliotecas de los centros penitenciários. Boletim de la Asociación de Bibliotecarios, n. 62, p. 79-89, mar. 2001.

GIDDENS, Anthony. As consequiências da modernidade. São Paulo: Edusp, 2002.

GIL, Antonio Carlos. Como elaborar projetos de pesquisa. São Paulo: Atlas, 1991.

GIL, Antonio Carlos. Métodos e técnicas de pesquisa social. São Paulo: Atlas, 1999.

GOFFMAN, E. Manicômios, Prisões e Conventos. 7. ed. Rio de Janeiro: Perspectiva, 2003. $320 \mathrm{p}$.

GOUVÊA, Roseli. A prática do psicólogo no sistema prisional do estado de São Paulo. São Paulo, 2007. 170 p. Dissertação (Mestrado em Psicologia Social). Pontifícia Universidade Católica de São Paulo, 2007.

HANNIGAN, Margaret C. The Librarian in bibliotherapy: pharmacistor bibliotherapist? Library Trends, Illinois, v. 11, n. 2, p. 184-198, oct. 1962.

HASSE, Margareth. Biblioterapia como texto: análise interpretativa do processo biblioterapêutico. 2004.2 Disponível em: <http://www.utp.br/proppe/edcient/BibliotecaVirtual/MCL/MargarethHasse/.pdf >. Acesso em: 15 abr. 2009.

HORNE, Erica M. A look at bibliotherapy. Special Libraries, Illinois, p. 27-31, jan. 1975.

INSTITUTO PRÓ-LIVRO. Retratos da leitura no Brasil. 2008. Disponível em: <http://www.prolivro.org.br/ipl/publier4.0/texto.asp?id=48>. Acesso em: 10 nov. 2009.

INTERNACIONAL FEDERATION OF LIBRARY ASSOCIATIONS AND

INSTITUTIONS, (Org.). Se necesitan Bibliotecarios de Prisiones: Una profesión estimulante para personas con las destrezas personales y profesionales adecuadas. 65th IFLA Council and General, Bangkok, Thailand, 1999. Disponível em:

<http://www.ifla.org/IV/ifla65/papers/046-132s.htm>. Acesso em: 10 nov. 2008.

INTERNATIONAL FEDERATION OF LIBRARY ASSOCIATIONS AND INSTITUTIONS. Guidelines for library services. 2005. Disponível em: <http://www.ifla.org/VII/s9/nd1/iflapr-92.pdf>. Acesso em: 10 nov. 2008.

ISER, Wolfgang. O ato da leitura: uma teoria do efeito estético. São Paulo: Editora 34, 1999. 
JOHN, V. M. "Palavras da salvação": as representações da leitura na prisão. Florianópolis, 2004. 192 p. Dissertação (Mestrado em Educação). Universidade Federal de Santa Catarina, 2004.

JULIÃO, Elionaldo Fernandes. Educação de jovens e adultos privados de liberdade: desafios para a política de reinserção social. EJA e educação prisional. Salto para o futuro, boletim 6, p. 3-13, 2007. Disponível em: 〈http://www.redlece.org/biblioteca/Juliao2.pdf>. Acesso em: 10 nov. 2008.

JULIÃO, Elionaldo Fernandes. Os sujeitos da educação de jovens e adultos privados de liberdade: questões sobre a diversidade. Salto para o futuro, boletim 6, p. 22-29, 2007. Disponível em: <http://www.redlece.org/biblioteca/Juliao2.pdf>. Acesso em: 10 nov. 2008.

KINNEY, Margaret. The bibliotherapy programs: requirements for training. Library Trends, Illinois, v.11, p. 129, oct. 1962.

KIPNIS, Bernardo. Elementos do processo de pesquisa. Seleção. Brasília, 2002.

KLEIMAN, Ângela. Texto e leitor: Aspectos Cognitivos da Leitura. 8. ed. Campinas, SP: Pontes, 2002.

LAJOLO, Marisa, ZILBERMAN, Regina. A formação da leitura no Brasil. São Paulo: Ática, 1996.

LAJOLO, Marisa. Leitura em crise na escola: alternativas do professor. São Paulo: Mercado Aberto, 1986.

LANCASTER, F. W. Ameaça ou oportunidade? O futuro dos serviços de biblioteca à luz das inovações tecnológicas. Revista da Escola de Biblioteconomia da UFMG, v. 23, n. 1, p. 727, jan./ jun. 1994.

LEMGRUBER, Julita. Cemitérios dos vivos. 2. ed. Rio de Janeiro: Forense, 1999.

LEMGRUBER, Julita. O sistema penitenciário brasileiro. In: CERQUEIRA, Daniel; LEMGRUBER, Julita (Org.). Criminalidade, violência e segurança pública no Brasil. Rio de Janeiro: IPEA, 2000. 
LIMA, Raimundo de. Metodologia científica: seguir ou inventar? Revista Espaço Acadêmico, São Paulo, n. 77, out. 2007. Disponível em: <http://www.espacoacademico.com.br/077/77lima.htm>. Acesso em: 23 set. 2009.

LIMA, Sandra P. Gomes de. Biblioteca em presídio. Brasília, 2002. Monografia (Graduação em Biblioteconomia). Universidade de Brasília, 2002. 39 p.

LIMA, Wannise de Santana. Leitura e cognição: uma abordagem hipertextual. 2001. Disponível em: <www.cce.ufsc.br/ fialho/ergcog/trab_alunos/.../Wanise.pdf>. Acesso em: 27 ago. 2009.

LOPES, Maria I. V. Pesquisa m Comunicação: formulação de um modelo metodológico. São Paulo: Loyola, 1990. 148 p.

LUCAS, Elaine; CALDIN, Clarice; SILVA, Patrícia Pinheiro da. Biblioterapia para crianças em idade pré-escolar: Estudo de caso. Perspect. Ciên. Inf., Belo Horizonte, v. 11, n. 3, p. 398-415, set./dez. 2006.

MACRI, Fabiana de Castilho; SALAZAR, José Nicolás Albuja. Um estudo sobre a gestão organizacional em centros de ressocialização do estado de São Paulo. Cadernos da Faceca, Campinas, v. 14, n. 1, p. 5-65, jan./jun. 2005.

MAGNABOSCO, Danielle. Sistema penitenciário brasileiro: aspectos sociológicos. Jus Navigandi, Teresina, ano 3, n. 27, dez. 1998. Disponível em: <http://jus2.uol.com.br/doutrina/texto.asp?id=1010>. Acesso em: 26 ago. 2009.

MANGUEL, A. Uma história da leitura. São Paulo: Companhia das Letras, 1997.

MARIA, Luzia de. Constituição do leitor. Rio de Janeiro: Centro Cultural Banco do Brasil, 1994.

MARTINS, Maria Helena. O que é leitura. 19. ed. São Paulo: Brasiliense, 1994.

MATTEWS, David; LONSDALE, Ray. Children in hospital: II. Reading therapy and children in hospital. Health Libraries Review, v. 9, n. 1, p. 14-26, 1992.

MENDES, Josué de Sousa. Formação do leitor de literatura: do hábito da leitura à cultura literária. Brasília, 2008. 223 p. Tese (Doutorado em Literatura e Práticas Sociais). Universidade de Brasília, 2008. 
MENDES, Rosa Maria B. P. A literatura e a biblioterapia para crianças com problemas de aprendizagem. Porto, Portugal, 2008. 133 p. Dissertação (Mestrado em Educação e Bibliotecas). Universidade Portucalense, 2008.

MIRACELLY, Karenine. Pelo livro, a ressocialização de presos. Folha da região, Araçatuba,São Paulo, 11 dez. 2005. Caderno Cidades. Disponível em: <http://www.folhadaregiao.com.br/noticia?50304\&PHPSESSID=f01b780d80c6e36b5b3e3d1 be46ab235>. Acesso em: 9 set. 2009.

MIRANDA, A. Os conceitos de organização baseada na informação e no conhecimento e o desenvolvimento de serviços bibliotecários. Ciência da Informação, v. 22, n.3, p. 227, 1993.

MIRANDA, Maria Rosa Pimentel Faria de. Informação, leitura e inclusão educacional e social nas bibliotecas braille de Campo Grande-MS: um estudo de caso. Brasília, 2006. Dissertação (Mestrado em Ciência da Informação). Universidade de Brasília, 2006.

MUAKAD, Irene Batista. Prisão albergue. São Paulo: Cortez, 1984.

NOGUEIRA, O. Pesquisa social: introdução às suas técnicas. 4. ed. São Paulo: Editora Nacional, 1980. 128 p.

NUNES, Lucilene; FRANCO, Lucimara Fernanda Martins. Biblioterapia: formação e atuação do bibliotecário. [2006?]. Disponível em: $<$ http://www.erebd.ced.ufsc.br/portal/Textos_Anais/biblioterapia.pdf>. Acesso em: 24 nov. 2008 .

OLIVEIRA, Daniela Carla de. O mediador de leituras na Penitenciária Estadual de Maringá. Acta Scientiarum. Human and Sciences. Maringá, v. 26, n. 1, p. 109-116, 2004.

OLIVEIRA, Fernando Amaral de. Os modelos penitenciários do século XIX: Brasil, Estados Unidos e Europa. In:, Seminário Nacional de História da Historiografia: historiografia brasileira e modernidade, 2007, Mariana, MG. Anais... Mariana, MG: UFOP, 2007.

OLIVEIRA, Z. C. P. de. O Bibliotecário e sua auto-imagem. São Paulo: Pioneira, 1983.

ORGANIZAÇÃO DAS NAÇÕES UNIDAS. PNUD - Programa das Nações Unidas para o Desenvolvimento. Relatório do Desenvolvimento Humano. Lisboa: Tricontinental, 1995. 
ORSINI, Maria Stella. O uso da literatura para fins terapêuticos: biblioterapia. Comunicações e Artes, n. 11, p. 139-149, 1982.

ORTEGA Y GASSET, José. Missão do bibliotecário. Tradução de Antônio Agenor Briquet de Lemos. Brasília: Briquet de Lemos, 2006. 82p.

OUAKNIN, Marc-Alain. Biblioterapia. Tradução de Nicolás Niymi Campanário. São Paulo: Loyola, 1996.

PAIVA, Simone Borges. A atuação do bibliotecário em projetos de biblioterapia. Marília, SP, 2003. 72 p. Monografia (Graduação em Biblioteconomia). Universidade Estadual Paulista, Marília, 2003.

PARDINI, Maria Aparecida. Biblioterapia! Encontro perfeito entre o bibliotecário, o livro e o leitor no processo de cura através da leitura. Estamos preparados para essa realidade? 2002. Disponível em: 〈http://www.sibi.ufrj.br/snbu/snbu2002/oralpdf/87.a.pdf>. Acesso em: 10 nov. 2008.

PEREIRA, Marília M. Guedes. A biblioterapia em instituições de deficientes visuais: um estudo de caso. João Pessoa, 1989. 318 p. Dissertação (Mestrado em Biblioteconomia). Universidade Federal da Paraíba, 1989.

PEREIRA, Marília M. Guedes. Biblioterapia: proposta de um programa de leitura para portadores de deficiência visual em bibliotecas públicas. João Pessoa: Ed. Universitária, 1996.

PÉREZ-PULIDO, Margarita. Acerca de lãs bibliotecas de prisiones y sus servicios. Educacion y Biblioteca, Madri, n. 85, p. 40-44, dez. 1997.

PÉREZ-PULIDO, Margarita. Prácticas de lectura em prisión: estudos de actitudes y comportamiento de los reclusos en el centro penitenciário de Badajoz. Anales de Documentación, n. 4, p. 193-213, 2001.

PERROT, M. Os excluídos da história: operários, mulheres e prisioneiros. 2. ed. Rio de Janeiro: Paz e Terra, 1994. (Coleção Oficinas da História, vol. 12).

PETIT, M. El papel de los mediadores. Educação y biblioteca: Distintos Acercamientos. Barcelona: Editorial Molino, p.5-19, 1999. 
POPPER, Karl. A lógica da pesquisa científica. São Paulo: Cultrix, 1993.

PRISÃO. [200-]. Disponível em: <http://pt.wikipedia.org/wiki/Pris\%C3\%A3o>. Acesso em: 15 nov. 2008.

RADFORD, G. P. Positivism, Foucault, and the fantasia of the library : conceptions of knowledge and the modern library experience. The Library Quarlerly, v. 62, n. 4, p. 408424, oct. 1992.

RANGANATHAN, Shiyali Ramamrita. The Five Laws of Library Science. London: Edward Goldston. 1931.

RATTON, Ângela Maria Lima. Biblioterapia. Revista da Escola de Biblioteconomia da UFMG, Belo Horizonte, v. 4, n. 2, p. 198-214, set. 1975.

REGRAS Mínimas para o Tratamento do Preso no Brasil. Brasília: Conselho Nacional de Política Criminal e Penitenciária, 1995.

REIS, Marivaldina Bulcão; CARVALHO, Kátia de. Atualidade da missão do bibliotecário: contribuição de José Ortegay Gasset. Salvador: [s.n], 2007. Disponível em: <http://dici.ibict.br/archive/00001110/>. Acesso em: 18 nov. 2008.

RIBEIRO, José Luis Duarte; ECHEVESTE, Márcia Elisa Soares; DANILEVICZ, Ângela de Moura Ferreira. A utilização do QFD na otimização de produtos, processos e serviços. Porto Alegre: FEEng / UFRGS, 2001.

RICHARDSON, Roberto J. Pesquisa social: métodos e técnicas. São Paulo: Atlas, 1999. 334 p.

ROBERT'S, Alvin H. Bibliotherapy: a technique for counselig blind people. Journal of visual impairment \& Blindness, Illinois, v. 78, n. 5, p. 197-199, may. 1984.

RODRIGO, Jonas. Estudo de caso: fundamentação teórica. Brasília: Vestcon, 2008. Disponível em: 〈www.vestcon.com.br/ft/3116.pdf〉. Acesso em: 25 out. 2009.

RODRIGUES, Gizella; MADER, Helena. Lotes são públicos. Correio Braziliense, Caderno Cidade, Brasília, 24 abr. 2008. 
ROLIM, Marcos. Mais educação, menos violência: caminhos inovadores do programa de abertura das escolas públicas nos fins de semana. Brasília: UNESCO, Fundação

Vale, 2008. $101 \mathrm{p}$.

ROMÁN, Antonio Martín. Bibliotecas en el tratamiento penitenciario. Información, Cultura Y Sociedad, Buenos Aires-Arg, n. 16, p.35-54, 2006.

ROSA, Aparecida Luciene Resende. As cartas de Ana Cristina César: uma contribuição para a Biblioterapia. Três Corações, 2006. 82 p. Dissertação (Mestrado em Letras). Universidade Vale do Rio Doce. Três Corações, MG, 2006.

RUBIN, Rhea Joyce. Using bibliotherapy: a guide to theory and practice. London: Oryx Press., 1978. 246 p.

SALA-MOLINS, Louis. Dicionário dos Inquisidores: Valência, 1494. Paris: Galilée, 1981. $284 \mathrm{p}$.

SALES, Fernanda de. O ambiente escolar e atuação bibliotecária: o olhar da Educação e da Biblioteconomia. Enc. Bibli.: Revista Eletrônica de Biblioteconomia e Ciência da Informação, Florianópolis, n. 18, ago./dez. 2004.

SANCHES, Ana Maria Valente. Bibliotecas de estabelecimentos prisionais. Jornal do Tocantins, Palmas, 24 mar. 2008. Disponível em: <http://www.prto.mpf.gov.br/info/info_detalhes_a.php?iid=2343\&ctg=\&sctg=>. Acesso em: 12 nov. 2008

SANDER, M. S. La función docente de la biblioteca y del bibliotecario en el contexto académico universitario : una cuestión de principios. Revista Interameric. de Bibliotecologia, v. 14, n. 2, p. 25-34, jul./dic. 1991.

SANTOS, Jocevaldo Gomes dos. Reintegração social do preso: utopia e realidade. Rev. CEJ., Brasília, n. 15, p. 30-34, set./dez. 2001.

SEITZ, Eva Maria. Biblioterapia: uma experiência com pacientes internados em clínica médica. Florianópolis, 2000. 79 p. Dissertação (Mestrado em Engenharia de Produção). Universidade Federal de Santa Catarina, 2000.

SHRODES, Caroline. Bibliotherapy: a theoretical and clinical-experimental study. 1949. 344 p. Dissertation (Doctor of Philosophy in Education). University of California, Berkeley, 1949. 
SILVA, Alexandre Magno da. Características da produção documental sobre biblioterapia no Brasil. 2005. 122 p. Dissertação (Mestrado em Psicologia). Universidade Federal de Santa Catarina, Florianópolis, 2005.

SILVA, Antônio Julião da. Plano Nacional de Segurança Pública e o sistema penitenciário . Jus Navigandi, Teresina, ano 4, n. 43, jul. 2000. Disponível em: <http://jus2.uol.com.br/doutrina/texto.asp?id=1601>. Acesso em: 29 out. 2009.

SILVA, Edna Lúcia da; MENEZES, Estera Muszkat. Metodologia da pesquisa e elaboração de dissertação. 3. ed. rev. e atual. Florianópolis: Laboratório de Ensino a distância da UFSC, 2001.

SILVA, Helena de Fátima Nunes. A biblioteca e suas representações: análises das representações de alunos e professores da UFPR. [199?]. Disponível em: <http://snbu.bvs.br/snbu2000/docs/pt/doc/t044.doc>. Acesso em: 17 out. 2009.

SILVA, Jorge Alberto Barros da; INOCÊNCIO, Zenira dos Santos. Educação e trabalho nos espaços prisionais: a educação como possibilidade de inserção no mercado de trabalho. Brasília, 2005. 75 p. Monografia (Especialização em Processos de Educação Na Vida Adulta), Departamento de Centro de Educação a Distancia, Universidade de Brasília, 2005.

SILVA, Nuno J. Espinosa Gomes da. História do direito português: fontes de direito. 4. ed. rev. e atual. Lisboa: Fundação Calouste Gulbenkian, 2006. 720 p.

TARGINO, Maria das Graças. Conceitos de biblioteca. Brasília: ABDF, 1984. 117 p.

UMA analise do sistema penitenciário. 2003. Disponível em: <http://www.nossacasa.net/recomeco/0075.htm>. Acesso em: 21 nov. 2008.

VIANA, Nildo. Sociedade, faixa etária e idade penal. Revista Espaço Acadêmico, n. 31, dez. 2003. Disponível em: < http://www.espacoacademico.com.br/031/31cviana.htm>. Acesso em: 10 nov. 2009.

VICENTE, Jorge. Biblioterapia. 2000. Disponível em: <http://form.ccems.pt/drama/bibliotecas.htm >. Acesso em: 25 ago. 2009.

WILSON-DAVIS, K. The Centre for Research on Users Studies: aims and functions. Asilib Proceedings, v. 29, n. 2, p. 65-69, feb. 1977. 


\section{APÊNDICES}


APENDICE A - Questionário aplica aos detentos do Centro de Internamento e Reeducação CIR

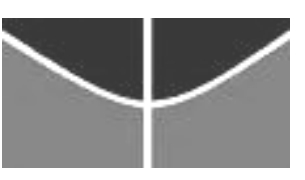

\section{UNIVERSIDADE DE BRASÍLIA}

Faculdade de Administração, Contabilidade, Economia e Ciência da Informação

Departamento de Ciência da Informação e Documentação

\section{Questionário sobre Biblioterapia e Bibliotecas de estabelecimentos prisionais}

Este questionário tem por finalidade coletar dados para um trabalho acadêmico. Os resultados poderão ser aplicados em futuros projetos de incentivo à leitura, bem como para o aprimoramento das bibliotecas de estabelecimentos prisionais.

1 - Idade: anos

2 - Qual sua escolaridade?

( ) $1^{\circ} \mathrm{Grau}$ Incompleto

( ) $1^{\circ}$ Grau Completo

( ) $2^{\circ} \mathrm{Grau}$ Incompleto

( ) $2^{\circ}$ Grau Completo

( ) Superior Incompleto

( ) Superior Completo

( ) Outros.

3 - Caso freqüente, com que constância vai à biblioteca por mês?

( ) todo dia

( ) 1 a 3 vezes por semana

( ) semanalmente

( ) quinzenalmente

( ) mensalmente

( ) outros.

4 - Marque os materiais que mais procura na Biblioteca. (Pode marcar mais de uma alternativa)
( ) Romance
( ) Ficção
( ) Livros didáticos
( ) Religião ( ) Auto-ajuda
( ) Científicos ( )Jurídicos
( )Outros.

5 - O que prefere ler?
( ) Livros
( ) Revistas
( ) Jornais
( ) História em quadrinhos (Gibis)
( ) Outros.

6 - O que o senhor acredita que a biblioteca possa proporcionar?
( ) Lazer/Diversão/Entretenimento
( ) Bem-estar físico/mental
( ) Adquirir conhecimento/Cultura
( ) Para passar o tempo
( ) Outros.

7 - Quantas horas por semana dedica à leitura?

( ) de 1 a 3 horas semanais

( ) de 3 a 5 horas semanais

( ) de 5 a 7 horas semanais

( ) mais de 7 horas semanais

( ) Outras.

8 - Quantos livros ler por mês?

( ) Nenhum

( ) de 1 a 3

( ) de 3 a 5

( ) mais de cinco

9 - Qual seu local preferido para leitura?

( ) na Cela

( ) na Biblioteca

( ) no Pátio da Prisão

( ) Outros.

10 - O senhor costuma pegar livros emprestados na Biblioteca?

( ) Sim, continuamente (sempre).

( ) Sim, casualmente (de vez em quando).

( ) Não. Por quê? 
11 - Quando lê, como se sente?

( ) se sente melhor mentalmente (mais calmo, confortado. satisfeito...).

( ) se sente melhor fisicamente (mais relaxado, desestressado...)

( ) sente que adquiriu conhecimento, cultura

( ) sente que apenas passou seu tempo

( ) não muda nada

( ) Outro.

12 - O senhor acredita que a leitura possa mudar o comportamento de uma pessoa?

( ) $\mathrm{Sim}$

( ) Não

13 - O senhor acredita que a leitura sirva como terapia
( ) $\mathrm{Sim}$
( ) Não

14 - O senhor acha importante ter ajuda de algum profissional para escolher $o$ que ler?
( ) Sim
( ) Não

15 - Qual horário prefere ler?
( ) Manhã
( ) Tarde
( ) Noite

16 - Com que freqüência costumava ler antes de ir para prisão?
( ) Continuamente (sempre)
( ) Casualmente (de vez em quando)
( ) Raramente
( ) Não lia

17 - Qual a sua maior dificuldade ao usar a Biblioteca?

( ) Qualidade dos livros

( ) Não encontro o livro que procuro

( ) Não gosto de ler.

( ) Outro.

18 - Qual sua opinião a respeito das Bibliotecas em prisões?

( ) São muito importantes

( ) Pouco importantes

( ) Irrelevantes (sem importância)

19 - O que o senhor sugere que possa ser modificado ou deva ser feito para a melhoria das bibliotecas em prisões? 
APÊNDICE B - Solicitação à Fundação de Amparo ao Trabalhador Preso

UNIVERSIDADE DE BRASILIA (UnB)

Faculdade de Economia, Administração, Contabilidade e Ciência da Informação e Documentação (FACE)

Departamento de Ciência da Informação e Documentação (CID)

Brasília, 11 de setembro de 2009

À Fundação de Amparo ao Preso - FUNAP

A/C. Sra. Rochane Gontijo Gomes Rocha - DIRASE/FUNAP

Prezada Senhora,

O aluno Leandro Lopes Trindade, matrícula 05/86421, é aluno regular do curso de Biblioteconomia desta Universidade, cursando seu último semestre.

Atualmente $o$ aluno está elaborando uma Monografia de final de curso, com o tema: Bibliotecas de Estabelecimentos Prisionais, necessitando coletar dados sobre duas (2) Bibliotecas nesses estabelecimentos.

Solicitamos, a V.Sa., que o referido aluno tenha acesso a duas Bibliotecas do Sistema Penitenciário do Distrito Federal.

Atenciosamente,

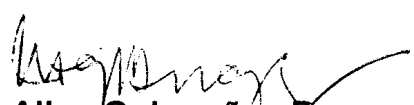

Prof. ${ }^{2}$ Maria Alice Guimarães Borges

Coordenadora do Curso de Graduação em Biblioteconomia UNB/FACE/CID

Edificio da Biblioteca Central (BCE) - Entrada Leste - Campus Universitário Darcy Ribeiro - Asa Norte - Brasília, DF CEP 70910-900 - Tel.: +55 (61) 3307-2422 - Fax: +55 (61) 3273-8454 - E-mail: cid@unb.br １8/9/2009 11:06:19 


\section{APÊNDICE C - Requerimento a Vara de Execuções Penais do Distrito Federal}

$E^{\circ} m^{\circ}$ Senhor

Juiz Titular da Vara de Execuções Penais - VEP

Luis Martius Holanda Bezerra Júnior

Senhor Juiz,

Leandro Lopes Trindade, brasileiro, solteiro, estudante, portada da cédula de

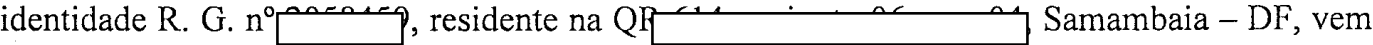
à presença de V. Ex ${ }^{\mathrm{a}}$ para expor e requerer o que segue:

O requerente é aluno regular do curso de Biblioteconomia desta universidade, cursando seu último semestre. Atualmente o aluno está elaborando uma Monografia de final de curso, com o tema Biblioterapía e Bibliotecas de estabelecimentos prisionais, necessitando coletar dados por meio de questionário, em anexo, aos detentos sobre alguma biblioteca prisional do Sistema Penitenciário do Distrito Federal.

Em nome do requerente, solicitamos a V. Ex a que o mesmo possa, aleatoriamente, aplicar de 10 (dez) a 20 (vinte) questionários para que alcance resultados suficientes para conclusão de sua pesquisa.

Pede Deferimento.

Brasília, 29 de setembro de 2009

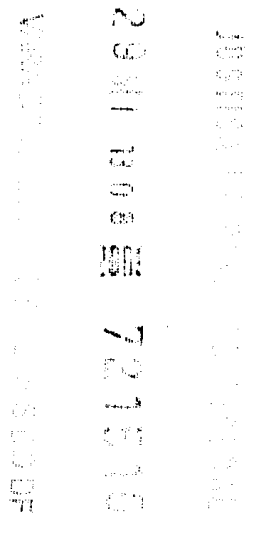

Coordenadora do Curso de Graduação em Biblioteconomia UNB/FACE/CID

Edificio da Biblioteca Central (BCE) - Entrada Leste - Campus Universitário Darcy Ribeiro - Asa Norte - Brasilia, DF CEP 70910-900 - Tel.: +55 (61) 3307-2422 - Fax: +55 (61) 3273-8454 - E-mail: cid@unb.br 29/9/2009 11:58:15 
APÊNDICE D - Requerimento a Subsecretaria do Sistema Penitenciário do Distrito Federal

\section{REQUERIMENTO}

Exmo. Senhor

Subsecretário do Sistema Penitenciário do Distrito Federal - SESIPE

Anderson Jorge Damasceno Espíndola

Senhor Secretário,

Leandro Lopes Trindade, brasileiro, solteiro, estudante e policial militar do Distrito Federal, portador da cédula de identidade R.G. $\mathrm{n}^{\circ} * * * * * * *$, residente na $\mathrm{QR} * * *$ Conjunto ** Casa **, Samambaia - DF, vem à presença de V. Exa. para expor e requerer o que se segue:

Por ser o requerente aluno regular do curso de Biblioteconomia da Universidade de Brasília e está elaborando uma Monografia de final de curso com o tema Biblioterapia e Bibliotecas de estabelecimentos prisionais, o mesmo necessita coletar dados por meio de questionários aos detentos que freqüentam alguma biblioteca prisional do Sistema Penitenciário do Distrito Federal.

Anteriormente a este foi requerido o mesmo propósito ao MM. Senhor Juiz da Vara de Execuções Penais do Distrito Federal, Luis Martius Holanda Bezerra Júnior, sendo deferido o pleito em consonância à concordância da Subsecretaria do Sistema Penitenciário.

Diante do exposto, a fim de se buscar alcançar exitosa conclusão da pesquisa de final de curso, requer a V. Exa. a autorização para aplicação dos questionários.

Termos em que pede deferimento.

Brasília, 19 de outubro de 2009.

LEANDRO LOPES TRINDADE

ANEXOS: Cópia do Requerimento à VEP; Cópia do Ofício proferido pela VEP; e, Cópia do questionário. 
APÊNDICE E - Entrevista

\section{ENTREVISTA}

1-Nome:

2-A formação universitário é suficiente para atuação do profissional em meio prisional?

3-Você acredita para que o bibliotecário atue em meio prisional é necessário aperfeiçoamento técnico?

4-Qual motivo levou você a trabalhar em bibliotecas prisionais?

5-Quanto tempo trabalha com presos?

6-Você gosta de trabalhar com presos? Por quê?

7-Você considera importante a existência de bibliotecas em estabelecimentos prisionais? Por quê?

8-Qual o papel social da biblioteca prisional?

9-Qual o maior entrave de ou em uma biblioteca prisional?

10-Você acredita que há possibilidade do uso da biblioterapia em prisões?

11-Quais as principais dificuldades do uso da biblioterapia em presos?

12-Você acredita que a biblioterapia possa auxiliar no bem-estar e no melhoramento comportamental do preso?

13-Em sua opinião como o preso ver a biblioteca prisional?

14-Como o preso ver o bibliotecário? Considera-se respeitado? 


\section{ANEXOS}




\section{缕 TIDFT Poder Judiciário e Territórios}

\section{VARA DE EXECUÇÕES PENAIS DO DISTRITO FEDERAL \\ Tribunal de Justiça do Distrito Federal e dos Territórios-SRTVS Qd. 701 - Bloco N-lote 08- $2^{\circ}$ andar-sala 204/205 Cartório - Brasilia (DF) - Telefone: (61) 3312-1515-Fax: (61) 3312-1525 - CEP 70.340-903}

Ofício nº 9.114/ VEP

Brasília, 6 de outubro de 2009.

Procedimento $n^{\circ}$ 2009.01.4.044644-4 - VEP

\section{Senhora Coordenadora,}

De ordem do MM. Juiz de Direito da Vara de Execuções Penais do Distrito Federal e em atenção aos termos do expediente datado de 29/09/2009, informo a Vossa Senhoria que, havendo concordância da Subsecretaria do Sistema Penitenciário - SESIPE (tel: 3901-6277), este Juízo não se opõe ao pleito formulado, para que o aluno Leandro Lopes Trindade possa aplicar questionário aos detentos, sobre alguma biblioteca prisional do Sistema Penitenciário do Distrito Federal, para fins de elaboração de sua Monografia final de curso.

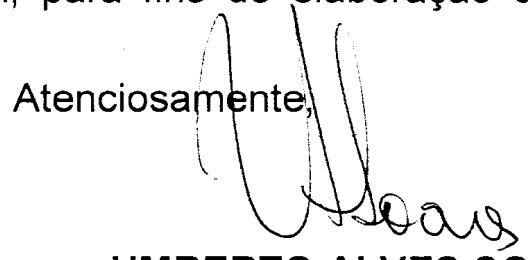

UMBERTO ALVES SOARES

Diretor de Secretaria Substituto

\section{À Senhora}

\section{MARIA ALICE GUIMARÃES BORGES}

\section{Coordenadora do Curso de Graduação em Biblioteconomia -} UNB/FACE/CID

Edifício da Biblioteca Central (BCE) - Entrada Leste - Campus Universitário Darcy Ribeiro - Asa Norte - CEP: 70910-900 - tel: 3307-2422 / Fax: 3273-8454

BRASÍLIA - DF 
ANEXO B - Memorando do Centro de Internamento e Reeducação - CIR

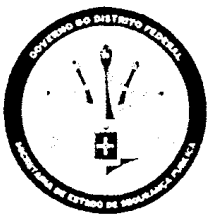

Ofício $n^{0} 3785 / 09$
GOVERNO DO DISTRITO FEDERAL SECRETARIA DE ESTADO DE SEGURANCA PÚBLICA SUBSECRETARIA DO SISTEMA PENITENCIÁRIO CENTRO DE INTERNAMENTO E REEDUCAÇÃO - CIR

Ref.: Memorando 3705 - SESIPE

Ofício ${ }^{\circ} 9.113 / 09 / \mathrm{Vep}$

Procedimento $n^{\circ} 2009.01 .4 .044644-4-V E P$

Para: Prof $f^{a}$. Maria Alice Guimarães Borges

Em resposta a vossa solicitação, referente aplicação do questionário sobre a Biblioteca Dirigida a Detentos, a ser realizada pelo aluno Leandro Lopes Trindade, do curso de Graduação em Biblioteconomia da UNB/FACE/CID, nos colocamos a disposição para aplicação do referido questionário.

Tendo em vista a rotina interna do presidio, faz-se necessário agendamento prévio, o qual, poderá ser feito pelos telefones: 3335-9501 ( $\mathrm{Sr}^{\circ}$ Adelmo) ou 9203-1098 ( Sr $^{\circ}$ Hélio Mendes).

Atenciosamente,
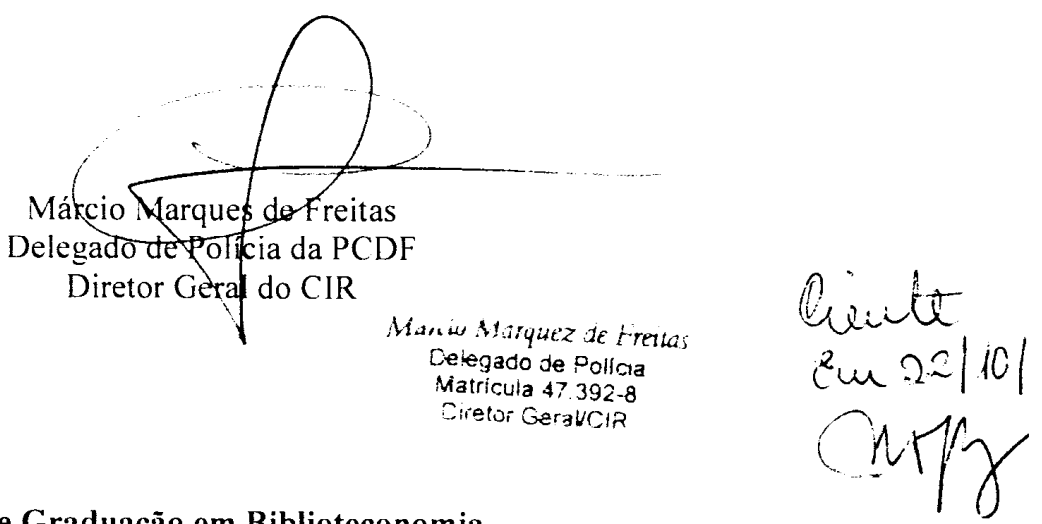

A Coordenadora do Curso de Graduação em Biblioteconomia

Profa. Maria Alice Guimarães Borges

Edifício da Biblioteca Central (BCE) - Entrada Leste

Campus Universitário Darcy Ribeiro

Asa Norte -- Brasília DF 


\section{ANEXO C - Lei distrital que cria a Biblioteca Nova Vida}

LEI N ${ }^{\circ} 1.663$, DE 15 DE SETEMBRO DE 1997

DODF DE 29.09.1997

Cria a Biblioteca Nova Vida no complexo penitenciário da Papuda e dá outras providências.

Faço saber que a Câmara Legislativa do Distrito Federal aprovou, o Governador do Distrito Federal, nos termos do $\S 3$ do art. 74 da Lei Orgânica do Distrito Federal, sancionou, e eu, Presidente da Câmara Legislativa do Distrito Federal, na forma do $§ 6$ do mesmo artigo, promulgo a seguinte Lei:

Art. $1^{\circ}$ Fica criada a biblioteca Nova Vida no complexo penitenciário da Papuda, observadas as condições estabelecidas nesta Lei.

Art. $2^{\circ}$ São objetivos da biblioteca Nova Vida do complexo penitenciário da Papuda:

I - facilitar o acesso à informação e promover a difusão da cultura entre os presidiários;

II - apoiar as atividades pedagógicas desenvolvidas no complexo penitenciário pela Fundação de Amparo ao Trabalhador Preso - FUNAP;

III - motivar os presos a freqüentarem a biblioteca com promoções culturais regulares que estimulem o hábito da leitura;

IV - cooperar com o programa de recuperação de presidiários desenvolvido pela FUNAP;

$\mathrm{V}$ - adquirir, conservar e preservar livros, periódicos e documentos.

Art. $3^{\circ} \mathrm{Na}$ lei orçamentária do Distrito Federal, constará dotação orçamentária específica, sob a rubrica manutenção e ampliação da biblioteca Nova Vida no complexo penitenciário da Papuda, destinada à Fundação de Amparo ao Trabalhador Preso.

Parágrafo único. A Fundação de Amparo ao Trabalhador Preso poderá firmar convênios com órgãos da administração direta e indireta e com organizações não governamentais para a aquisição e conservação de livros, periódicos, documentos e equipamentos suplementares em geral.

Art. $4^{\circ} \mathrm{O}$ Poder Executivo, por intermédio da Secretaria de Segurança Pública do Distrito Federal, tomará as medidas necessárias à implantação desta Lei e a regulamentará no prazo de sessenta dias.

Art. $5^{\circ}$ Esta Lei entra em vigor na data de sua publicação.

Art. $6^{\circ}$ Revogam-se as disposições em contrário.

Brasília, 15 de setembro de 1997

$109^{\circ}$ da República e $38^{\circ}$ de Brasília

CRISTOVAM BUARQUE 
ANEXO D - Decreto distrital que regulamenta a implantação e o funcionamento da Biblioteca Nova Vida

DECRETO N ${ }^{\circ}$ 26.637, DE 16 DE MARÇO DE 2006

DODF DE 17.03.2006

Regulamenta a implantação e o
funcionamento da Biblioteca Nova Vida
no Complexo Penitenciário da Papuda,
criada pela Lei $\mathrm{n}^{\circ}$. 1.663, de 15 de
setembro de 1997, e dá outras
providências".

O GOVERNADOR DO DISTRITO FEDERAL, no uso das atribuições que lhe confere o artigo 100, inciso VII, da Lei Orgânica do Distrito Federal, e tendo em vista o disposto no artigo $4^{\circ}$ da Lei ${ }^{\circ} 1.663$, de 15 de setembro de 1997, DECRETA:

Art. $1^{\circ}$ A Biblioteca Nova Vida do Complexo Penitenciário da Papuda terá sua sede no Setor de Ensino do Centro de Internamento e Reeducação - CIR da Subsecretaria do Sistema Penitenciário - SESIPE, órgão executivo do Sistema de Segurança Pública e Defesa Social do Distrito Federal.

Parágrafo único - A Fundação de Amparo ao Trabalhador Preso - FUNAP poderá criar novas unidades da Biblioteca Nova Vida nos outros estabelecimentos penais do Distrito Federal, após anuência da Subsecretaria do Sistema Penitenciário.

Art. $2^{\circ}$ A Biblioteca Nova Vida tem como objetivos facilitar o acesso à informação, apoiar as atividades pedagógicas desenvolvidas junto aos estabelecimentos penais do Distrito Federal pela Fundação de Amparo ao Trabalhador Preso - FUNAP, promover a difusão da cultura, estimular o hábito da leitura e cooperar com o processo de recuperação dos internos.

Art. $3^{\circ}$ Compete à Fundação de Amparo ao Trabalhador Preso - FUNAP a aquisição, conservação e preservação de livros, periódicos e documentos necessários ao pleno funcionamento da Biblioteca Nova Vida, bem como sua organização e administração.

Art. $4^{\circ}$ A Fundação de Amparo ao Trabalho Preso - FUNAP poderá utilizar a mão-de-obra de internos do Sistema Penitenciário para o trabalho interno desenvolvido na Biblioteca Nova Vida, nos termos do art. 28 e seguintes da Lei nº. 7.210/84 - Lei de Execução Penal.

Art. $5^{\circ}$ A Secretaria de Estado de Segurança Pública e Defesa Social expedirá as normas necessárias à implantação e disciplinamento da utilização da Biblioteca Nova Vida.

Art. $6^{\circ}$ Este Decreto entra em vigor na data de sua publicação.

Art. $7^{\circ}$ Revogam-se as disposições em contrário.

Brasília, 16 de março de 2006.

$118^{\circ}$ da República e $46^{\circ}$ de Brasília

JOAQUIM DOMINGOS RORIZ 